\title{
Infection and Inflammation in progression of Atherosclerosis : the role of Chlamydiae pneumoniae infection in different mouse models
}

Citation for published version (APA):

Ezzahiri, R. (2007). Infection and Inflammation in progression of Atherosclerosis : the role of Chlamydiae pneumoniae infection in different mouse models. [Doctoral Thesis, Maastricht University]. Universiteit Maastricht. https://doi.org/10.26481/dis.20071123re

Document status and date:

Published: 01/01/2007

DOI:

10.26481/dis.20071123re

Document Version:

Publisher's PDF, also known as Version of record

Please check the document version of this publication:

- A submitted manuscript is the version of the article upon submission and before peer-review. There can be important differences between the submitted version and the official published version of record.

People interested in the research are advised to contact the author for the final version of the publication, or visit the DOI to the publisher's website.

- The final author version and the galley proof are versions of the publication after peer review.

- The final published version features the final layout of the paper including the volume, issue and page numbers.

Link to publication

\footnotetext{
General rights rights.

- You may freely distribute the URL identifying the publication in the public portal. please follow below link for the End User Agreement:

www.umlib.nl/taverne-license

Take down policy

If you believe that this document breaches copyright please contact us at:

repository@maastrichtuniversity.nl

providing details and we will investigate your claim.
}

Copyright and moral rights for the publications made accessible in the public portal are retained by the authors and/or other copyright owners and it is a condition of accessing publications that users recognise and abide by the legal requirements associated with these

- Users may download and print one copy of any publication from the public portal for the purpose of private study or research.

- You may not further distribute the material or use it for any profit-making activity or commercial gain

If the publication is distributed under the terms of Article $25 \mathrm{fa}$ of the Dutch Copyright Act, indicated by the "Taverne" license above, 


\section{Infection and Inflammation in progression of Atherosclerosis:}

the role of Chlamydiae pneumoniae infection in different mouse models 



\title{
Infection and Inflammation in progression of Atherosclerosis:
}

the role of Chlamydiae pneumoniae infection in different mouse models

\author{
PROEFSCHRIFT \\ ter verkrijging van de graad van doctor \\ aan de Universiteit Maastricht, \\ op gezag van de Rector Magnificus, \\ Prof. mr. G.P.M.F. Mols \\ volgens het besluit van het College van Decanen, \\ in het openbaar te verdedigen \\ op vrijdag 23 november 2007 om 10.00 uur
}

door

Rajaa Ezzahiri

Geboren op 8 februari 1976 te Breda 
Promotores:

Prof.dr. C.A. Bruggeman

Prof.dr. P.J.E.H.M. Kitslaar

Copromotores:

Dr. H.A.J.M. Kurvers (Radboud Academisch Ziekenhuis Nijmegen)

Dr. F.R.M. Stassen

Beoordelingscommissie:

Prof.dr. M.J.A.P. Daemen (voorzitter)

Prof.dr. J.W. Cohen-Tervaert

Prof.dr. J.A.J.W. Kluytmans (VU, Amsterdam)

Prof.dr. J.L. Waltenberger

ISBN: $978-90-808755-4-8$

NUR: 883

Layout: B-Point, 's-Hertogenbosch

Druk: Gildeprint, Enschede

Dit proefschrift is mede mogelijk gemaakt door research grants van Pfizer BV en ZonMW AGIKO stipendium. 


\section{Contents}

$\begin{array}{lll}\text { Chapter } 1 & \text { General Introduction } & 7\end{array}$

Chapter 2 Short communication: systemic dissemination of Chlamydiae pneumoniae after intratracheal and intraperitoneal infection, a study in C57 black mice

Chapter 3 Chlamydiae pneumoniae accelerates formation of complex atherosclerotic lesions in Apo E3-Leiden mice

Chapter 4 Chlamydiae pneumoniae infections augment atherosclerotic lesion formation: a role for serum amyloid $\mathrm{P}$

Chapter 5 Unstable atherosclerotic lesions and premature death in LDL-receptor, ApoE double knockout mice following Chlamydiae pneumoniae infection

Chapter 6 Anti-Chlamydiae pneumoniae and anti-inflammatory properties of azithromycin in atherosclerotic mice

$\begin{array}{lll}\text { Chapter } 7 & \text { General Discussion } & 107\end{array}$

$\begin{array}{lll}\text { Chapter } 8 & \text { Samenvatting } & 121\end{array}$

$\begin{array}{ll}\text { Dankwoord } & 125\end{array}$

$\begin{array}{ll}\text { Curriculum Vitae } & 127\end{array}$ 
CHAPTER 1

General Introduction 


\section{List of abbreviations}

\begin{tabular}{|c|c|}
\hline $\mathrm{AHA}$ & American Heart Association \\
\hline ApoE-/- & Apolipoprotein knockout \\
\hline bFGF & basic fibroblast growth factor \\
\hline CMV & cytomegalovirus \\
\hline COPD & chronic obstructive pulmonary disease \\
\hline Cpn & Chlamydia pneumoniae \\
\hline EB & elementary body \\
\hline EC & endothelial cells \\
\hline ECM & extracellular matrix \\
\hline EIA & enzyme immuno-assay \\
\hline eNOS & endothelial nitric oxide synthase \\
\hline E-selectin & endothelial selectin \\
\hline HB-EGF & heparin-binding epidermal-like growth factor \\
\hline H. pylori & Helicobacter pylori \\
\hline HDL & high density lipoprotein \\
\hline Hep-2 & human epithelial cell \\
\hline ICAM-1 & intercellular adhesion molecule \\
\hline IFN $\gamma$ & interferon gamma \\
\hline $\lg$ & immunoglobulin \\
\hline IGFBP4 & insulin-like growth factor binding protein 4 \\
\hline IL & interleukin \\
\hline LDL & low density lipoprotein \\
\hline LPS & lipopolysacharide \\
\hline MCMV & murine CMV \\
\hline MCP-1 & macrophage colony stimulating protein \\
\hline MHSP65 & microbial heat shock protein 65 \\
\hline MIF & macrophage inducible factor \\
\hline MMP & matrix metalloproteinase \\
\hline MOMP & major outer membrane protein \\
\hline NF- B & nuclear factor \\
\hline NO & nitric oxide \\
\hline oxLDL & oxidised LDL \\
\hline PAl-1 & plasminogen activator inhibitor 1 \\
\hline PCR & polymerase chain reaction \\
\hline PDGF & platelet derived growth factor \\
\hline RB & reticulate body \\
\hline ROS & intracellular reactive oxygen species \\
\hline SMC & smooth muscle cell \\
\hline TF & tissue factor \\
\hline TNF $\alpha$ & tumor necrosis factor \\
\hline VCAM-1 & vascular cell adhesion molecule \\
\hline VLA-4 & very late activation antigen \\
\hline
\end{tabular}




\section{Preface}

Atherosclerotic disease is a complex condition with multiple contributing factors that may induce progression of clinical symptoms leading to unstable atherosclerotic plaques, ischemia and ultimately death. Yet, more than one third of the patients dying of coronary disease do not have any of the known risk factors. ${ }^{1,2}$ Therefore, studies concerning possible other risk factors for atherosclerosis are of extreme importance in the treatment of cardiovascular disease.

One of these factors potentially involved in atherosclerosis is infection. In particular, Chlamydia pneumoniae (Cpn), an obligate intracellular micro-organisms which causes (asymptomatic) upper airway infections, has drawn the attention of both clinical and basic scientists. Since the late 80 's of the previous century, sero-epidemiological as well as experimental studies have supported a role for $\mathrm{Cpn}$ in the development and/or progression of atherosclerosis. The mechanisms by which Cpn contributes, if any, are still unknown. In this thesis, we tried to unravel some of the mechanisms by studying the influence of $\mathrm{Cpn}$ infection on atherosclerosis by using well established animal models.

\section{Introduction}

In the next sections we will briefly describe the etiology of atherosclerotic disease and the factors that are involved in the progression of atherosclerosis. First, the process of chronic inflammation, various mediators of the inflammatory process and the role of several pathogens causing infection of the vascular wall will be described. Then the epidemiology of Cpn and possible role of this micro-organism in the pathogenesis of the atherosclerotic process will be mentioned. Sero-epidemiological studies, clinical trials and experimental studies will be discussed to clarify several lines of evidence that link Cpn and atherogenesis.

\section{Atherosclerosis}

Cardiovascular disease continues to be the principal cause of death in Western countries. ${ }^{3}$ Complications of cardiovascular disease result in high morbidity and disability. Since this disease has a multi-organ character (myocardial infarction, cerebrovascular accident, peripheral arterial disease) diagnosis and treatment require a multidisciplinary treatment. Consequently the health care systems are confronted with high costs due to cardiovascular disease.

The main cause of cardiovascular disease is atherosclerosis, a systemic disease of the medium-sized and large arteries which ultimately affects all long living humans and may be present throughout one's lifetime. This process starts with early lesions in infants and children and progresses to an advanced atherosclerotic plaque after the 
third decade of life. Finally, clinical symptoms occur later in life usually from the fifth decade. ${ }^{4}$

The localisation of the atherosclerotic lesion in the vascular bed determines its clinical manifestation. Atherosclerotic lesions in the coronary arteries may cause myocardial infarctions, while instable plaques in the carotid arteries may lead to transient ischemic attacks and stroke. In the renal arteries, plaques may cause renal ischemia and hypertension. Peripheral arterial vascular disease results from stenosis of arteries in the peripheral segment of the arterial tree (iliac, femoral, crural arteries) leading to lower limb ischemia and in the long run to critical limb ischemia (rest pain and/or gangrene). Occlusion/stenosis of the mesenteric arteries causes mesenteric ischemia ("angine abdominale") and bowel infarction.

In contrast to the familiarity with the clinical symptoms of atherosclerosis, its pathogenesis still needs to be elucidated. In the last decades several risk factors have been identified in the initiation and/or progression of atherosclerosis, like hypercholesterolemia, diabetes mellitus, hypertension, smoking, genetic alterations and obesity. Diagnosis and treatment of these risk factors is important to prevent development and progression of atherosclerotic disease.

\section{Severity of atherosclerosis: lesion classification and composition}

During the course of atherosclerotic plaque development various lesion types have been identified, ranging from small clinically silent lesions to large ruptured lesions with prominent intraplaque hemorrhage. Atherosclerotic lesions are classified according to histological observations, as described by the Committee on Vascular Lesions of the Council on Arteriosclerosis and approved by the American Heart Association (AHA). ${ }^{4,5}$ The classification divides the atherosclerotic process in six stages as shown in table 1 . Type I-II are classified as early lesions that are clinically silent, while type IV and V plaques are designated as advanced lesions consisting of a fibrous cap surrounding a necrotic core. Stable advanced lesions can progress into unstable plaques which ultimately can lead to rupture of the fibrous cap and formation of a thrombus. This final stage is called a ruptured plaque or type VI lesion and is the underlying process in most acute clinical manifestations.

The initiation of atherosclerosis is characterised by adhesion of monocytes to the endothelium of the vascular wall, followed by diapedesis of monocytes into the subendothelial space and differentiation of monocytes into macrophages. When lipids accumulate in the macrophages foam cells appear, which are characteristic for a fatty streak or type I/II lesion according to the AHA classification. When lysis of foam cells occurs and more monocytes are recruited to the plaque, the fatty streak lesion progresses into a type III lesion containing extracellular lipids. Advanced lesions, type IV, contain a necrotic core, which consists of extracellular lipids and cholesterol-ester crystals, and a fibrous cap containing smooth muscle cells (SMC) cells, attracted from the media, and extracellular matrix (collagen). The fibrous cap overlies the necrotic core. Type $\mathrm{V}$ lesions can be subdivided in (I) $\mathrm{Va}$, the fibroatheroma, consisting of 
fibrous tissue and lipids, (II)type Vb, containing calcified segments and (III)type Vc lesions showing a fibrous component. The advanced lesions can be either stable, with a thick fibrous cap, rich in collagen and SMC or unstable, with a thin fibrous cap and a large lipid core. A thin fibrous cap is prone to rupture and leads to thrombus formation on the highly thrombogenic necrotic core. The resulting lesion is called a type $\mathrm{VI}$ lesion and is responsible for the clinical symptoms of atherosclerotic cardiovascular disease.

Table 1: Classification of lesion types

\begin{tabular}{|c|c|c|c|}
\hline $\begin{array}{l}\text { Lesion } \\
\text { type }\end{array}$ & Nomenclature & Main histology & \\
\hline Type I & Initial lesion & $\begin{array}{l}\text { Isolated macrophage foam cells, adaptive } \\
\text { thickening intima (smooth muscle cells) }\end{array}$ & Early lesions \\
\hline Type II & Fatty streak & Intracellular lipid accumulation & \\
\hline Type III & Intermediate lesion & $\begin{array}{l}\text { Type II ch anges with small extracellular lipid } \\
\text { pools }\end{array}$ & \\
\hline Type IV & Atheroma & Type II changes with lipid core & \\
\hline Type V & Fibroatheroma & $\begin{array}{l}\text { Fibrotic cap surrounding a lipid core with fibrous } \\
\text { tissue and lipids }(\mathrm{Va}) \text {, calcifications }(\mathrm{Vb}) \text {, or } \\
\text { fibrous component }(\mathrm{Vc})\end{array}$ & $\begin{array}{l}\text { Advanced } \\
\text { lesions }\end{array}$ \\
\hline Type VI & Complicated lesion & $\begin{array}{l}\text { Cap disruption, hematoma -hemorrhage, } \\
\text { thrombus }\end{array}$ & \\
\hline
\end{tabular}

\section{Aetiology of atherosclerosis}

In the pathogenesis of atherosclerosis several hypotheses have been postulated to elucidate the mechanism by which atherosclerotic lesions develop and progress. In the 70's Ross and co-workers described the response-to-endothelial-injury hypothesis. ${ }^{6}$ According to this hypothesis, local injury and activation of the endothelium caused by hyperlipidemia, mechanical injury or low shear stress activates the arterial SMC of the media to migrate to the intima and proliferate, also formation of connective-tissue matrix and deposition of lipids occur. ${ }^{7}$ Furthermore, lipid-laden macrophages and Tlymphocytes appear in the subendothelial space. ${ }^{8}$ With continued injury to the endothelium, SMC further proliferate and accumulation of connective tissue and lipid occurs. The response-to-injury hypothesis has been continually modified ${ }^{2}$ describing endothelial dysfunction rather than endothelial injury. Elevated levels of modified low density lipoprotein (LDL), free radicals due to cigarette smoking are, among others, possible causes of endothelial dysfunction. Due to dysfunction of the endothelium, compensatory responses occur that lead to an increased adhesiveness and perme- 
ability of the endothelium for leukocytes (mainly macrophages and T-cells). These cells are the most important contributors in the initiation and progression of atherosclerotic lesions. Endothelial dysfunction also induces upregulation of leukocyte adhesion molecules, like VCAM and ICAM-1. Then, growth factors like PDGF and bFGF, and cytokines (IFN $\gamma$ and IL-1) induce differentiation of monocytes into macrophages and activation of macrophages and T-cells. When the dysfunction of the endothelium (due to e.g. hypercholesterolemia or hypertension) continues, cell influx and proliferation lead to the formation of more advanced lesions. ${ }^{8,9}$

Besides the endothelial dysfunction hypothesis, the hypothesis of atherosclerosis as a chronic inflammatory disease has prevailed since the 90 's. ${ }^{2,8,10}$ An inflammatory response in atherosclerotic disease is initiated by chemotaxis and adhesion to the endothelium. The endothelium is activated to express leukocyte adhesion molecules like E-selectin, ICAM-1 and VCAM-111 which recruit mononuclear leukocytes, i.e. monocytes and T-cells, to the vessel wall. Adhesion of leukocytes to the endothelium is initiated by rolling on the endothelial surface under the influence of selectins, followed by adhesion to the endothelium which is dependent on the interaction between VCAM-1, ICAM-1 and very late- activation antigen-4 (VLA-4). The latter is expressed by monocytes and lymphocytes. ${ }^{11}$ Adhesion is then followed by migration of the leukocytes through the endothelium into the subendothelial space. Several chemokines (MCP-1), ${ }^{11}$ cytokines (IL-2, IFN $\left.\gamma\right)^{12}$ and fragments of complement proteins $(\mathrm{C} 5 \mathrm{a})^{11}$ promote chemotactic migration of monocytes and T-cells into the tissue of the arterial wall.

Once activated monocytes and T-cells have arrived at the site of injury, they act as scavengers to remove the injured tissue and start the regenerating process. Macrophages secrete cytokines, oxygen radicals, proteases, complement factors and present antigens. After antigen presentation by macrophages, T-cells are activated and either secrete cytokines ( $T$ helper cells), or mediate cytotoxic activity against cells that express proteosomally processed peptides (cytoxic T-cells). Also, activated Tcells upregulate transcription factor NF- $\mathrm{kB}$ resulting in the release of IFN- $\gamma$ and activation of macrophages. Oxidation of low-density lipoprotein (oxLDL), in the subendothelial space stimulates SMC proliferation ${ }^{13}$ and the immune complex of oxLDL and antioxLDL antibody are taken up by macrophages resulting in additional release of proinflammatory cytokines such as IL-1 $\beta$ and TNF- $\alpha .{ }^{14}$ After uptake of oxLDL by macrophages, foam cells are formed, which represents early lesion formation.

At this stage, macrophages secrete cytokines and growth factors that induce activation and proliferation of SMCs which migrate to the neointima and contribute to collagen synthesis. All these processes enhance the formation of an advanced atherosclerotic lesion. Also, activated macrophages produce and secrete matrix metalloproteinases (MMPs), that may degrade extracellular matrix (ECM) ultimately leading to a vulnerable plaque with a high risk of rupture. 


\section{Infection and atherosclerosis}

At the beginning of the 20th century, Sir William Osler was the first to suggest a potential link between infections and progression of atherosclerosis ${ }^{15} \mathrm{His}$ initial observation was confirmed by Frothingham ${ }^{16}$ and Klotz and colleagues. ${ }^{17}$ Since then, bacteria such as Helicobacter pylori, Chlamydia pneumoniae (Cpn) and viruses such as cytomegalovirus (CMV) and influenza have been suggested as mediators of the inflammatory response leading to progression of atherosclerosis. ${ }^{18-20}$ Several sero-epidemiological studies, randomised controlled trials and experimental studies have been performed to elucidate the mechanism by which infections contribute to the progression of atherosclerotic disease.

\section{Cytomegalovirus}

More than 25 years ago, Benditt ${ }^{21}$ and Fabricant ${ }^{22}$ proposed a potential role for viral infections in atherosclerosis by demonstrating that chickens develop atheroscleroticlike lesions after infection with an avian herpesvirus, Marek disease virus. Since then CMV has been linked to restenosis, ${ }^{23}$ transplantation-associated arteriosclerosis ${ }^{24-26}$ and atherosclerosis. ${ }^{27,28}$ Evidence regarding a role for $\mathrm{CMV}$ in atherosclerosis is based on sero-epidemiological studies and detection of CMV by culture, immunohistochemical staining, PCR or in situ hybridisation. ${ }^{10,29,30}$ Furthermore, Zhou et al. demonstrated that high IgG CMV antibodies in patients prior to coronary atherectomy was an independent risk factor for restenosis. ${ }^{31}$. In transplantation associated arteriosclerosis, several cross-sectional and prospective studies have linked CMV infection to graft rejection ${ }^{32,33}$ while experimental studies in rats using the aortic transplant mode ${ }^{34-36}$ have demonstrated that influx of monocytes/macrophages and T-cells was seen in the adventitia of the allograft, thereby indicating that CMV interacts with the immune system in the transplanted vessel wall. Besides the role of CMV in restenosis and transplantation-associated arteriosclerosis, CMV is also linked to atherosclerosis. ${ }^{37}$ Sero-epidemiological studies ${ }^{38}$ and animal models ${ }^{39}$ were used to corroborate a line of evidence that $\mathrm{CMV}$ infection contributes to progression of atherosclerosis. ${ }^{31,40,41}$

\section{Influenza}

Death from myocardial infarction is more common in winter than in summer thereby suggesting a role for respiratory infections in cardiovascular mortality. 42,4343 This has been affirmed by a large case-control study of 9571 patients which demonstrated that an acute respiratory infection is a risk factor for acute myocardial infarction. ${ }^{44}$ Also, influenza vaccination has been reported to protect against recurrent myocardial infarction, primary cardiac arrest, ${ }^{45,46}$ ischemic stroke ${ }^{47}$ and to reduce the rate of hospitalisation and deaths of congestive heart failure. ${ }^{45}$ Several mechanisms for the role of influenza in cardiovascular disease have been postulated. Firstly, influenza A has been demonstrated to affect plasma lipoproteins in mice. This is caused by loss of the 
anti-inflammatory nature of HDL, an increase in thrombogenic proteins and enhanced susceptibility of LDL oxidation. ${ }^{48}$ Secondly, an increase in cytokine production of IL-6, TNF- $\alpha$ and MCP-1 has been demonstrated in lung tissue and blood after influenza infection. ${ }^{49}$ These cytokines are known to enhance the progression of atherosclerosis. Other mechanisms potentially involved are endothelial apoptosis, ${ }^{50}$ endothelial dysfunction, ${ }^{51}$ and loss of thromboresistance. ${ }^{50}$

\section{Helicobacter pylori}

Helicobacter pylori (H.pylori) is a gram negative pathogen that infects the mucus layer of the stomach and is associated with gastritis and peptic ulcer disease. ${ }^{52}$ Since the first report of H.pylori seropositivity in patients with coronary heart disease in 1994, ${ }^{53}$ several studies have either confirmed ${ }^{54-57}$ or refuted ${ }^{58,59}$ the hypothesis that H.pylori influences atherogenesis through low-grade, persistent inflammatory stimulation. Furthermore, a recent report describes the correlation of H.pylori infection with antibodies to mHSP65 and elevated levels of coronary calcification, suggesting that pathogen-triggered autoimmunity plays a role in early atherosclerosis. ${ }^{60}$

\section{Periodontal infections}

Periodontal disease is a disease of the oral cavity characterised by infection and inflammation of the supporting structures of the teeth including periodontal ligament, cementum and alveolar bone. ${ }^{61}$ Chronic periodontitis has been reported to cause a low-grade asymptomatic bacteraemia with activation of the coagulation system and an increase in serum fibrinogen level thereby enhancing the inflammatory response of atherosclerosis. ${ }^{61,62}$ Case-control studies and population-based studies ${ }^{63-65}$ have corroborated the association between periodontal infection and atherosclerosis. In vivo studies with $\mathrm{ApoE}+/$ - mice have shown that long term systemic challenge with Porphyromonas gingivalis, an oral pathogen, can accelerate atherogenic plaque progression. ${ }^{66}$ In this study the oral pathogen was administrated intravenously, while Lalla and coworkers used the oral infection route for inoculation of ApoE -/- mice and found that periodontal infection increases vascular inflammation (elevated levels of IL-6, increased aortic expression of VCAM-1 and tissue factor) and early atherosclerotic lesion formation ${ }^{67}$ In patients, tooth loss, a marker of past periodontal disease, is related to carotid artery plaque prevalence as shown by Desvarieux et al. ${ }^{68}$ Proposed explanations for the role of periodontal infection in atherosclerotic vascular disease are transient bacteremia with systemic spread of infection from the oral cavity, endothelium injury by circulating oral microbial toxins and systemic inflammation triggered by oral micro-organisms. ${ }^{66,67,69}$ 


\section{Chlamydia pneumoniae}

While the pathogens mentioned previously have all been associated to some degree with atherosclerosis, the strongest evidence for an association between pathogens and atherosclerotic disease comes from studies on Chlamydia pneumoniae (Cpn). ${ }^{18,70}$

In the following paragraph, an overview of taxonomy, epidemiology, pathogenesis, and diagnosis of Cpn will be discussed. Several lines of evidence that link Cpn infection with atherogenesis will be presented.

\section{Taxonomy}

Cpn was first isolated in 1965 from the eye of a child during the trachoma vaccine study in Taiwan by inoculation of material from the child's conjunctiva in the yolk sac of an embryonating egg. ${ }^{71}$ The isolated strain was called TW-183. It was approximately 20 years later that $\mathrm{Cpn}$ was isolated from several patients with acute respiratory tract infections. ${ }^{72,73}$ The isolated strain was called AR-39. Since then, this Cpn strain has been displayed as TWAR (TaiWan Acute Respiratory disease), which is a combination of TW-183 and AR-39 strain. ${ }^{73}$

Recently, Everett described the taxonomy of Chlamydia bacteria (Chlamydiales) by classifying them in four families based on genetic relationships: Chlamydiaceae, Parachlamydiaceae, Simkaniaceae and Waddliaceae. ${ }^{74}$ By using analyses of ribosomal and coding genes on Chlamydiaceae, evidence was found for 2 new genera, Chlamydia and Chlamydophila and 9 different species. (table 2)

Table 2: Main characteristics of the Chlamydiaceae ${ }^{74}$

\begin{tabular}{|c|c|c|c|c|}
\hline Genus & Species & Route of entry & Host & Infected tissues \\
\hline \multirow{6}{*}{ Chlamydophila } & pneumoniae & pharynx,eye & $\begin{array}{l}\text { human, koala, } \\
\text { horse }\end{array}$ & artery, brain, joint, lung \\
\hline & psittaci & pharynx, eye, genitalia & bird & $\begin{array}{l}\text { brain, eye, genitalia, intestine, } \\
\text { liver, lung, spleen }\end{array}$ \\
\hline & pecorum & oral & $\begin{array}{l}\text { cattle, she ep, } \\
\text { pig, koala }\end{array}$ & $\begin{array}{l}\text { bladder, brain, eye, intestine, } \\
\text { lymph, joint, prostate }\end{array}$ \\
\hline & felis & pharynx, eye, genitalia & house cat & eye, genitalia, joint, lung \\
\hline & caviae & pharynx, eye, genitalia & guinea pig & bladder, eye, genitalia, lung \\
\hline & abortus & oral, genital mammals & sheep & $\begin{array}{l}\text { intestine, placenta, spleen, fetal } \\
\text { liver }\end{array}$ \\
\hline \multirow{3}{*}{ Chlamydia } & trachomatis & $\begin{array}{l}\text { pharynx, eye, genitalia } \\
\text { rectum }\end{array}$ & human & $\begin{array}{l}\text { eye, gentalia ,joint, prostate, } \\
\text { neonatal lung }\end{array}$ \\
\hline & suis & pharynx & swine & eye ,intestine, lung \\
\hline & muridarum & pharynx,genitalia & $\begin{array}{l}\text { mouse, } \\
\text { hamster }\end{array}$ & $\begin{array}{l}\text { genitalia, intestine, li ver, lung, } \\
\text { kidney, spleen }\end{array}$ \\
\hline
\end{tabular}




\section{Microbiology}

Chlamydiae are obligatory intracellular bacteria with a unique biphasic life cycle characterised by elementary bodies(EBs), which are infectious, 0.2-0.6 mm in diameter and reside in extracellular form, and the reticulate bodies (RBs). In the beginning of the replication cycle after attachment to the host cell, EBs are ingested by endocytosis and transformed in RBs. These RBs are up to $1.5 \mathrm{~m}$ in diameter, take up nutrients from the host cell and undergo several rounds of binary division within the endosome, leading to enlargement of the cell and formation of an inclusion (RBs are also displayed as inclusion bodies). Transition from RB back into infectious EBs occurs approximately 36 hours after host cell infection, with subsequently release at about 48 hours through exocytosis or rupture of the host cell. A new replication cycle is initiated when infectious EBs attach to new host cells.

The cell-wall of Chlamydiae consists of a Gram-negative envelope without peptidoglycan, although Chlamydia trachomatis and Cpn encode for proteins forming a pathway for synthesis of peptidoglycan and penicillin binding proteins. ${ }^{75,76}$ This is indicated by the term "Chlamydial peptidoglycan paradox". Chlamydiae also have a lipopolysacharide (LPS) antigen and utilize host adenosine triphosphate for synthesis of Chlamydial protein. ${ }^{77}$ In addition, all Chlamydiae encode a protein called the major outer membrane protein (MOMP), that is the major determinant for serological classification of chlamydial isolates ${ }^{78}$ and is surface-exposed in Chlamydia trachomatis and Chlamydia psittac ${ }^{79,80}$

An interesting phenomenon is the fact that Chlamydiae may remain in a persistent state instead of initiating a new replication cycle. This may occur after treatment with antibiotics, interferon- $\gamma$ (IFN- $\gamma$ ) or restriction of certain nutrients, ${ }^{77}$ During this persistent state, metabolic activity is reduced and subclinical infection is prolonged, which is one of the major characteristics of Chlamydiaceae (including Cpn). ${ }^{81}$ This phenomenon is important in achieving eradication of $\mathrm{Cpn}$ by antibiotic therapy.

\section{Pathogenesis of Cpn infection}

Recent studies have shown that not only acute respiratory infections are associated with $\mathrm{Cpn}$ infection: such as Alzheimer's disease, ${ }^{82}$ asthma, ${ }^{83}$ atherosclerosis, ${ }^{84}$ COPD,${ }^{85}$ multiple sclerosis, ${ }^{86}$ and reactive arthritis. ${ }^{87}$

Most respiratory infections caused by $\mathrm{Cpn}$ are subclinical with only a small percentage resulting in clinically apparent pneumonia. This pneumonia is named "atypical" pneumonia. Several other pathogens have also been shown to be involved in this so called "atypical" pneumonia such as Legionella and Mycoplasma pneumoniae. ${ }^{88}$ The so called "typical" pneumonia is caused by the more "classical" bacteria such as Streptococcus pneumoniae, Hemophilus influenzae, Pseudomonas aeruginosa and Staphylococcus aureus. Approximately $10 \%$ of all pneumonia cases and $5 \%$ of all pharyngitis and sinusitis cases are caused by Cpn. ${ }^{89}$ There is not a set of signs and symptoms unique to Cpn lower respiratory tract infections, although several signs and symptoms may support that $\mathrm{Cpn}$ plays a causal role. Early presentation of the disease with pharyngitis, dry cough, and headache can be observed. Cough and malaise can 
persist for many weeks but most cases of $\mathrm{Cpn}$ induced pneumonia have a mild course not necessitating hospitalisation. 89,90

\section{Epidemiology of Cpn infection}

Sero-prevalence of $\mathrm{Cpn}$ varies from 50 to $70 \%$ among adults, which indicates that this pathogen is a common cause of infection. Cpn IgG antibody levels are very low or absent in children under the age of $5 .{ }^{91}$ They increase from the beginning of primary school age until adolescence, with an incidence of about $10 \%$ in those aged 5-10 years. By the age of 20 , prevalence of specific IgG has already reached $50 \%$, which may even increase with age. ${ }^{92-95} \mathrm{~A}$ low endemic level of $\mathrm{Cpn}$ infections is alternated with epidemics occurring every 2-4 years and have been reported to occur especially in closed communities such as the military. 96 The mode of transmission is probably through respiratory tract secretions. The duration of spread of infection is low, 5 to 7 months, compared to 2 weeks for influenza. ${ }^{97}$ Incubation period for Cpn infection is estimated at 3 to 4 weeks. ${ }^{98,99}$

Diagnostic tests for Cpn

Laboratory tests are used to diagnose acute respiratory tract disease. Although no standard laboratory protocol is available yet, ${ }^{88,100}$ the following tests are used: antibody detection (serology), culture of Cpn, detection of Cpn DNA/RNA by PCR and detection of Cpn antigens by immunohistochemistry. ${ }^{101}$

First, diagnostic tools for acute $\mathrm{Cpn}$ infection will be evaluated in this paragraph followed by diagnostic tests used to detect chronic $\mathrm{Cpn}$ infection, which will be described in the next section.

\section{Serology}

Patients with acute primary $\mathrm{Cpn}$ infection, develop IgM antibodies 2 to 3 weeks after onset of the illness. IgM antibodies can be detected until 2 to 6 months afterwards. In contrast, IgG antibody reaches a high titer after 6-8 weeks and can be detected for over 3 years after primary infection, ${ }^{102}$ while IgA response is delayed, weak or absent. ${ }^{103}$ In the case of reinfection, IgM may not appear at all and IgG increases fast within 1 to 2 weeks after onset. Because interpretation of single high $\lg G$ titers is difficult, especially in elderly patients who have persistently elevated IgG levels due to multiple Cpn infections in the past, convalescent serum specimens are needed to show a 4 fold increase in titer. This often provides only a retrospective diagnosis of acute infection, making this diagnostic tool not optimal for patient management. However, it is useful in determination of prevalence of infection in epidemiological studies and in the case of an outbreak.

To analyse $\mathrm{Cpn}$ antibody titers in serum, the micro-immuno-fluorescence (MIF) test or enzyme immunoassays (EIA) are used. ${ }^{104}$ Although MIF is considered the golden standard in chlamydia serology, it is difficult to standardise and different criteria are used for interpretation. ${ }^{105}$ Therefore, several laboratories prefer the EIA for antibody detection using either recombinant LPS, other Cpn proteins, Cpn bacteria or extract- 
ed antigens..$^{81}$ These assays are either genus-specific, or are species-specific, respectively. In order to detect acute Cpn infection, paired serum samples, obtained 4-8 weeks apart, should be used. When IgM is detected at a titer of $\geq 1: 16$ or $\lg G$ shows a 4-fold increase, acute Cpn infection can be considered, while IgG titers of $\geq 1: 512$ are suggestive of an acute Cpn infection. ${ }^{101}$

\section{Culture}

For detection of viable $\mathrm{Cpn}$, the cell culture technique can be used. Culture procedures are based on inoculation via centrifugation of a specimen (swabs of oropharynx, nasopharynx, sputum specimens, bronchoalveolar lavage specimens or biopsy specimens) onto human cells, mainly Hep-2 cells, grown in vitro. After incubation, cells are stained with a fluorescent-labelled antibody specific to $\mathrm{Cpn}$ to visualise the bacteria that are multiplying within these cells.

This test is labour intensive since multiple passages (at least 2) are necessary before a specimen can be considered negative. Special expertise is required for distinguishing true $\mathrm{Cpn}$ inclusions from artefacts, which is corroborated by the fact that only few laboratories are using this technique to detect $\mathrm{Cpn}$ in specimens of patients with infections. Therefore, culture is not recommended for large scale use in diagnostic laboratories..$^{90}$

Because of the low yield and technical complexity of culture, other tests, such as polymerase chain reaction (PCR), have been developed and are widely used for detection of Cpn. ${ }^{101}$

\section{PCR}

PCR is considered a validated test for detection of Cpn DNA during acute infections, ${ }^{106}$ because it is reasonably fast and highly sensitive. ${ }^{107}$ PCR enables detection of DNA and of RNA of pathogens that are present in small numbers, nonviable or growing slowly. Also, material not suitable for culture such as large tissue specimens, can be used in PCR analysis. 108 However, for routine use of Cpn PCR, several issues should be taken into consideration: choice of primers, optimalisation of the assay, extraction of nucleic acids, detection of amplification products and prevention and identification of false-positive and false-negative results. ${ }^{106}$ The most frequently used primers have been based on the omp1 gene, the 16S rRNA gene, the 16S-23S spacer rRNA genes and a Cpn-specific cloned Pstl fragment. ${ }^{106}$ For detection of the amplification product, agarose gel electrophoresis, Southern blot, EIA and polyacrylamide gel electrophoresis can be used. ${ }^{81}$ To establish reproducibility of $\mathrm{Cpn}$, detection of cDNA by reverse transcription-PCR of mRNA may be useful. ${ }^{109}$ Lately, real-time quantitative PCR assays, allow highly reproducible, sensitive and specific quantification of $\mathrm{Cpn}$ in cultures and clinical samples. ${ }^{110}$

\section{Immunohistochemistry}

Finally, detection of Cpn antigens by immunocytochemistry, using genus-or speciesspecific antibodies labelled with a peroxidase or a fluorescent marker provide valuable 
information concerning presence and localisation of $\mathrm{Cpn}$ to specific areas and cells in infected tissue. ${ }^{111}$ Also, it offers the advantage of preserving tissue morphology, although no information can be obtained about the presence of viable bacteria. Detection of LPS can be achieved by using CF-2, a Chlamydia genus-specific monoclonal antibody, while RR402 and TT401 are Cpn-specific antibodies directed against elementary bodies of $\mathrm{Cpn}$. Background staining ${ }^{112}$ and nonspecific staining ${ }^{113}$ can make interpretation of results difficult and may decrease the specificity of this diagnostic tool.

\section{Cpn diagnosis in atherosclerotic vascular disease}

In chronic diseases that have been linked to Cpn infections standardised approaches for laboratory testing are lacking. In the following paragraph, the diagnostic tools available for detection of $\mathrm{Cpn}$ infection in atherosclerotic vascular disease will be described.

\section{Serology}

Diagnosis of a chronic Cpn infection by means of serology is still very challenging, since no serological marker has been validated. Although several studies have attempted to correlate single sample $\lg G$ or $\lg A$ antibody levels with disease status, no equivocal results found mainly because of the use of different cut-off points and methodologies. ${ }^{103,114}$ Also, it has been proposed that high IgA titers (half-life of 5 to 7 days) may be a better marker of chronic $\mathrm{Cpn}$ infection than the use of $\lg G$ antibody (half-life of weeks to months). ${ }^{101,103}$ The line between chronic and past infection is not completely clear since 1) past infection is also diagnosed by antibody detection and 2) detection of $\mathrm{Cpn}$ remnants without viable bacteria, a method suggested for diagnosis of past infection, is almost impossible to demonstrate and is therefore not in use. When the MIF and EIA technique were compared, the agreement between EIA and MIF in detection of IgG and IgA antibodies was adequate. ${ }^{115}$ Therefore, EIA may be a practical alternative to the MIF technique to diagnose (chronic) Cpn infection in patients with cardiovascular disease.

\section{Culture}

Culture of $\mathrm{Cpn}$ from blood vessels is technically challenging and has been successful in only very few cases when multiple serial passages were used. ${ }^{116-118}$ Nonetheless, culture remains important to document the viability of the organism and, to provide isolates of the organism for characterisation and for evaluation of antimicrobial susceptibility. Also, for assessment of microbiological efficacy in treatment trials culture remains an essential diagnostic tool. ${ }^{119}$ Dowell and colleagues described recommendations for culture in atherosclerotic vascular disease. ${ }^{101}$ One of the controversies regards the number of passages used before the results are determined. ${ }^{116,120,121}$ Most laboratories used more than 2 passages to maximise the recovery of Cpn isolates from respiratory specimens. But when increased passages are used it may result in concentration of cell debris and possible non-specific staining of the monolayer thus resulting in false positive data. 


\section{PCR}

Although PCR is considered a validated method for detection of Cpn DNA in acute infections, for chronic infections no standardised protocol is available yet. In chronic infections, the bacterium is mostly present in very small quantities, which necessitates a highly sensitive PCR thereby increasing the risk of contamination. ${ }^{106}$ Studies have shown that in these cases DNA extraction procedures and storage conditions of samples play a pivotal role. ${ }^{106}$ Also, atherosclerotic tissue is known to contain inhibitors of PCR, which makes it difficult to estimate the prevalence of Cpn in vascular tissue material. Nowadays, with the diversity of PCR techniques, a rise in shortcomings have also been detected, which has stimulated several laboratories to develop their own inhouse PCRs. Therefore, consensus of the best Cpn PCR has not been ascertained yet. ${ }^{122}$ This also explains the reported interlaboratory variation in the performance of PCR tests.

\section{Immunohistochemistry}

Detection of Cpn antigens in human vascular plaque material using immunostaining showed variable detection rates from 21 to $71 \%$ between different laboratories. ${ }^{123,124}$ Moreover, when in the same atherosclerotic lesion presence of Cpn was analysed using different methods: culture, PCR and/or immunohistochemistry, a poor correlation was observed. ${ }^{123-125}$ Interestingly, Cpn detection rates determined by immunohistochemistry are higher than those determined by PCR. This can be assigned to several factors: 1. DNA shows faster degradation than antigens, 2. extraction of DNA from plaques can be difficult, due to calcifications and 3. presence of PCR inhibitors may result in false negative PCR results. ${ }^{123,124,126}$ These observations show that the interpretation of the discrepant results from different studies is difficult in the absence of a gold standard. Recently, guidelines have been formulated ${ }^{101}$ which makes it possible to obtain optimal results from immunohistochemistry. These guidelines recommend to use 2 Chlamydia antibodies and 2 control antibodies for each tissue block. Also, staining should run 1 positive and 1 negative tissue control, each incubated with the 4 antibodies. When interpreting the intracytoplasmatic staining of cells a granular pattern may be considered positive, while a homogeneous staining pattern is controversial. ${ }^{101}$

Since different monoclonal antibodies vary in type and specificity, detection rates vary widely, which emphasises the importance of the use of the same monoclonal antibodies when comparing results of different studies. ${ }^{108}$

\section{Association Cpn and atherosclerosis}

Sero-epidemiological studies have reported an association of Cpn antibodies with myocardial infarction, chronic coronary heart disease ${ }^{84}$ and an increased relative risk for cardiovascular complications. ${ }^{127}$ The presence of Cpn DNA ${ }^{128}$, Cpn antigen ${ }^{118,128}$ and viable $\mathrm{Cpn}^{118}$ in the vascular wall has been associated with atherosclerosis. However, these studies did not demonstrate the mechanism by which infections could contribute to the progression of atherosclerotic disease, leaving the "innocent bystander" hypothesis (Cpn would be an innocent bystander instead of a moderator of 
the atherosclerotic process) open for discussion. In vitro and in vivo studies ${ }^{129-131}$ have attempted to unravel the role of $\mathrm{Cpn}$ infection in atherosclerosis. Also, by using antibiotics directed against $\mathrm{Cpn}$ infection, insight can be gained in the role of $\mathrm{Cpn}$ infection in the progression of atherosclerotic disease.

Role of Cpn infection in the atherosclerotic process: studies in animal models Animals that have been used to study the effect of Cpn infection on progression of atherosclerosis are mainly normocholesterolemic and hypercholesterolemic rabbits (New Zealand White rabbits) and mice (C57 Black/6J. Apolipoprotein knockout, ApoE3-Leiden and low density lipoprotein-receptor knockout mice). In the following paragraph, the role of $\mathrm{Cpn}$ infection on the progression of atherosclerosis will be discussed using animal models and in vitro studies.

C57 Black/6J (C57BL/6J) mice on a normal diet do not develop atherosclerosis, even after intranasal infection of $\mathrm{Cpn} .{ }^{132}$ However, when an atherogenic diet was supplemented to these mice, fatty streak lesions were observed in the aortic root, which represents early atherosclerosis lesion formation. ${ }^{133}$ By using this mouse strain to evaluate the effect of $\mathrm{Cpn}$ infection on atherosclerotic lesion progression, Blessing and colleagues found that chronic $\mathrm{Cpn}$ infection accelerates lesion development in hypercholesterolemic C57BI/6J mice. ${ }^{134}$ When the atherogenic diet was given following $\mathrm{Cpn}$ infection, no atherosclerotic lesion progression was observed, ${ }^{135}$ suggesting that $\mathrm{Cpn}$ is a co-risk factor for cardiovascular disease. Another study has confirmed this observation: in low density lipoprotein-receptor knockout mice (LDL-receptor-/-) the atherogenic effect of Cpn infection is dependent on the presence of hyperlipidemia. ${ }^{136,137}$ Also, Tiirila and colleagues showed that acute Cpn infection causes a transient increase in serum triglycerides and lipid binding protein, one of the key proteins involved in lipoprotein metabolism in mice. ${ }^{138}$ Hyperlipidemia plays a pivotal role in oxidation of LDL in the vascular wall, leading to foam cell formation. In contrast to these observations, several studies have reported progression of atherosclerosis independent of hyperlipidemia. ${ }^{139-141}$

Moazed et al. ${ }^{140,142}$ demonstrated that intranasal Cpn infection of Apolipoprotein knockout (ApoE-/-) mice results in a significant increase in lesion area. Other groups using ApoE-/- mice studied the effect of repeated Cpn infections on endothelial dysfunction and found that infection impaired arterial endothelial function, with a pivotal role for the nitric oxide (NO) pathway in endothelial signalling. ${ }^{129,143-145}$ This is supported by Chesebro et al. ${ }^{139}$ who demonstrated an increase in lesion size in wild type mice, fed a high cholesterol diet, following Cpn infection. This increase was comparable to the increase in lesion size in endothelial NO synthase knockout mice. However, no additional effect of $\mathrm{Cpn}$ infection was observed in these knockout mice suggesting that Cpn infection results in endothelial dysfunction with subsequent atherosclerosis. Besides in the thoracic aorta of ApoE-/- mice, endothelial dysfunction after Cpn infection has also been demonstrated in epicardial and resistance vessels of pigs. ${ }^{146}$

In addition to the association between $\mathrm{Cpn}$ infection and endothelial dysfunction, the role of pro-inflammatory cytokines in the progression of atherosclerosis has been 
described in different reports. In vitro infection by $\mathrm{Cpn}$ of human U-937 macrophages increases the production of IL-1 $\beta$, IFN- $\gamma$ and TNF- $\alpha$, while infection of human coronary artery endothelial cells induces IL-8 production indicating a chemokine reponse to infection that may play a role in recruitment of inflammatory cells to sites of infected vascular cells. ${ }^{147} \mathrm{~A}$ recent in vivo study by Burián et al. ${ }^{148}$ evaluated the role of inflammatory cytokines after Cpn infection of Balb/c mice. Increased levels of IL-3, -6, -4 and IFN- $\gamma$ were detected in lungs tissue. The same research group evaluated the inflammatory process in the aortic vascular wall of normocholesterolemic Balb/c mice after co-infection with $\mathrm{Cpn}$ and CMV. ${ }^{149}$ Although no atherosclerotic lesions were observed, the combined effect of MCMV and Cpn induced inflammatory foci in the aortic wall which were more pronounced in the co-infected mice than in the mice infected with MCMV alone.

Also in rabbits a few studies have evaluated the role of $\mathrm{Cpn}$ infection in atherosclerotic lesion progression. ${ }^{141,150,151}$ Using normocholesterolemic New Zealand White rabbits, atherosclerotic lesions in the aorta were observed following single intranasal $\mathrm{Cpn}$ infection ${ }^{150,151}$ and multiple infections ${ }^{141}$ providing further evidence for a role for $\mathrm{Cpn}$ in atherosclerotic disease initiation and/or progression.

Role of Cpn infection in the atherosclerotic process: in vitro studies

Next to Cpn research in animal models, in vitro studies have been used to elucidate mechanisms by which Cpn may contribute to atherosclerosis.

Previous studies demonstrated that the organism is able to infect many cell types at cardiovascular sites, including circulating monocytes, arterial smooth muscle cells (SMC) and vascular endothelial cells (EC). Infected cells exhibit characteristics associated with the development of cardiovascular disease, such as achievement of procoagulant state and secretion of pro-inflammatory cytokines by infected EC and foam cell formation by infected macrophages. ${ }^{152}$

In the initiation of atherogenesis, endothelial dysfunction and subsequent release of inflammatory mediators plays an essential role. It has been demonstrated that $\mathrm{Cpn}$ is able to infect circulating CD14+ mononuclear cells of humans ${ }^{153}$ and $\mathrm{Cpn}$ was detected in blood of mice infected intranasally with $\mathrm{Cpn} .{ }^{154}$ Probably, Cpn uses the mononuclear cells as a vehicle for entry into the vessel wall. ${ }^{155}$ Instead of using mononuclear cells for entry into the vessel wall, Cpn may also enter through adventitial layers of large blood vessels. Another mechanism by which $\mathrm{Cpn}$ may enter the vessel wall is by direct cell-cell transmission from mononuclear cells to EC. ${ }^{156}$ Molestina and colleagues ${ }^{157}$ have demonstrated that Cpn infection of EC induces IL-8 and MCP-1 thereby stimulating transendothelial migration of monocytes and neutrophils and differentiation of monocytes into macrophages. In addition, after infection of human vascular EC an upregulation of various adhesion molecules (VCAM-1, ICAM-1, P-selectin, Eselectin) and IL-6, IL-8, II-1 $\beta$, TNF- $\alpha$, and MCP-1 has been reported. ${ }^{156-160}$ Since adhesion molecules are important in leukocyte rolling and adhesion and subsequent extravasation of leukocytes into the intima, these in vitro data suggest a contributory role for $\mathrm{Cpn}$ in atherosclerotic lesion development. 
It has been demonstrated that $\mathrm{Cpn}$ infects the main cell types of the atherosclerotic lesion, such as macrophages, SMC, EC and T-cells. ${ }^{161}$ Activation of these cells results in a continuous release of inflammatory mediators. Collectively, these data support that Cpn infection of the vascular wall is involved in the chronic inflammatory process. ${ }^{155,162}$ Activation of T-lymphocytes in the plaque can be established by antigens like ox-LDL. ${ }^{163-165} \mathrm{Cpn}$ has also been shown to activate T-cells cultured from peripheral blood of patients with atherosclerosis as well as T-cells cultured from carotid endarterectomy tissue. ${ }^{166}$ Recently, it has even been demonstrated that Cpn can infect lymphocytes of human peripheral blood and mouse spleens as well as a T-lymphocyte cell line. ${ }^{167} \mathrm{~T}$-cells upregulate the transcription factor NF- $\mathrm{KB}$ resulting in release of IFN $\gamma$ and activation of macrophages. ${ }^{155}$ The extracellular release of chlamydial antigens including LPS and HSP-60 all contribute to the inflammatory response. cHSP-60 induces T-cells to produce TNF- $\alpha,{ }^{168}$ a potent pro-inflammatory cytokine which contributes to oxidation of LDL ${ }^{169}$ while antibodies to HSP-60 are cytotoxic for EC. ${ }^{170}$ This could result in additional release of inflammatory mediators. LPS induces EC production of reactive oxygen species which contributes to the formation of oxLDL within the neointima. ${ }^{62}$ Subendothelial oxLDL stimulates SMC proliferation ${ }^{13}$ and immune complexes of oxLDL and anti-oxLDL antibody are taken up by macrophages resulting in additional release of pro-inflammatory cytokines IL-1 $\beta$ and TNF- $\alpha .{ }^{14}$

Evidence for involvement of $\mathrm{Cpn}$ in the formation of foam cells and fibrous caps has been established by several in vitro studies. ${ }^{155}$ Kalayoglu and coworkers demonstrated that Cpn LPS induced oxidation of LDL, uptake of oxLDL by macrophages and subsequent foam cell formation. ${ }^{169,171}$ Atherosclerotic lesion progression is characterised by advanced plaques consisting of a fibrous cap surrounding a necrotic core. In the process of cap formation, activation of SMC and production of the ECM and MMPs play a pivotal role. ${ }^{2}$ Kol et al. ${ }^{159}$ have shown that CHSP-60 stimulates MMP-2 and -9 production by macrophages. This may contribute to breakdown of ECM and internal elastic lamina. Cpn infected EC release soluble factors that stimulate SMC proliferation $^{130}$ and induce upregulation of SMC growth factors and related proteins (PDGF-B, b-FGF, HB-EGF, IGFBP4) as demonstrated by DNA microarray studies. ${ }^{160}$

In the final stage of atherogenesis, plaque erosion, rupture and thrombus formation have been linked to the presence of $\mathrm{Cpn}$. Macrophages have been shown to produce MMPs after being stimulated with cHSP-60 or $\mathrm{Cpn}^{159,172}$ This may alter the ECM, thereby contributing to plaque destabilisation and rupture. After $\mathrm{Cpn}$ infection of SMC, an upregulation of TF and PAI-1 was observed, thereby enhancing a procoagulant condition. ${ }^{173,174}$ Furthermore, activated macrophages and SMC release reactive oxygen species. This contributes to cellular cytotoxicity, activation of CD8+ T-cels and formation of necrotic core. ${ }^{175-177}$ A recent study by Nazzal and co workers ${ }^{178}$ observed an increase in necrotic cell death after infection of human EC with Cpn. This process was modulated by ox LDL and was correlated with an increase in intracellular reactive oxygen species (ROS) concentration, which is considered to be involved in the orientation of cells toward necrosis. Increase of necrotic cell death in the atherosclerotic lesion could further aggregate to rupture of the plaque. 
Antibiotic therapy for prevention or stabilisation of the atherosclerotic process in animals

Since several lines of evidence have linked Cpn infection with progression of atherosclerotic vascular disease, ${ }^{179}$ the question was posed whether antibiotic therapy would be an option for prevention or stabilisation of the atherosclerotic process. ${ }^{180}$ To define the duration and quantity of antibiotic treatment several animal models were used.

Muhlestein and coworkers infected $30 \mathrm{New}$ Zealand White rabbits on an atherogenic diet with 3 separate Cpn inoculations (3.105 inclusion forming units, IFU) or saline at 3 weeks intervals and treated them with azithromycin or no therapy for 7 weeks. ${ }^{181}$ Maximal intimal thickness as well as plaque area in the thoracic aorta was increased in the infected rabbits compared to both uninfected controls and infected rabbits receiving antibiotics.

Using clarithromycin therapy after 3 intranasal Cpn infections (2 weeks apart) in rabbits, Fong et al. found a reduction in the number of plaques and a reduction in the $\mathrm{Cpn}$ antigen content in the vascular tree. ${ }^{182}$ Treatment beginning early after inoculation, was more effective than delayed treatment (starting 2 weeks after inoculation and continuing for 6 weeks).

Earlier studies performed by the same group, ${ }^{183,184}$ reported similar results although azithromycin was used instead of clarithromycin with shorter treatment protocols. ${ }^{183}$ Comparison of different antimicrobials with antichlamydial activity (azithromycin, clarithromycin, moxifloxacin, doxycycline) demonstrated that early treatment i.e., within 5 days after infection with all antibiotics, prevents aortic lesions (efficacy $75 \%$ for clarithromycin and $85 \%$ for azithromycin). Delayed treatment, 6 weeks after infection, with azithromycin was ineffective in reducing atherosclerotic lesions, while clarithromycin resulted in $62.5 \%$ reduction. ${ }^{184}$

Using ApoE-/- mice, Rothstein and colleagues explored the hypothesis that azithromycin therapy inhibits the atherogenic effects of $\mathrm{Cpn}$ infection. ${ }^{185}$ Ten-week old mice were infected twice with 5.106 IFU Cpn or placebo and treated with azithromycin 2 weeks after the last infection. Although Cpn infection increased lesion size of the aortic lesion in infected mice, azithromycin therapy did not reduce plaque area. Therefore, the authors concluded that immediate therapy of acute infection may be necessary to prevent the proatherogenic effects of Cpn infection.

In line with these results, Blessing and coworkers ${ }^{186}$ observed no effect of azithromycin therapy on reduction of atherosclerotic lesion progression in ApoE-/mice after infection with $\mathrm{Cpn}$. Mice were inoculated three times once a week with 3.107 IFU Cpn and treated with azithromycin for 6 weeks starting 3 days after the last inoculation. This study shows that the start of antibiotic treatment immediately after the last inoculation ${ }^{181}$ is essential in these animal models to prevent acceleration of lesion progression. Furthermore, the inoculation protocol used in the present study ${ }^{186}$ is much higher (weekly 3.107 IFU) than the dosage used by Muhlestein ${ }^{181}$ (3 separate inoculations, 3.105 IFU, 3 weeks apart). 


\section{Outline of this thesis}

Atherosclerosis is a multifactorial disease. It is generally accepted that inflammation of the vascular wall plays an important role in its development. Cpn infection has been proposed as one of the multiple moderators of the inflammatory process.

In this thesis, several possible mechanisms by which Cpn may aggravate the atherosclerotic process have been evaluated. First we studied the systemic dissemination of Cpn after intratracheal and intraperitoneal infection in C57B/6/J mice (Chapter 2). This mouse strain was used since it is the genetic background for breeding of most of the transgenic and knockout mice (ApoE3-Leiden, ApoE -/-, and LDLreceptor, ApoE double knockout mice) used in atherosclerotic studies. In Chapter 3 , we used one of these atherosclerotic mouse strains (ApoE3-Leiden) to study the effect of Cpn infection on atherosclerosis progression (plaque area/type) and inflammatory processes in the atherosclerotic vascular wall. Mice were infected with Cpn and sacrificed at different time points post infection. As Cpn significantly accelerated the formation of complex lesions, we decided to study the effect of Cpn infection on plaque formation in normal C57BI6J mice fed an atherogenic diet. These mice normally develop only early lesions and we hypothesised that additional, multiple Cpn infection may result in the formation of more complex lesions (Chapter 4). In a subsequent study we evaluated whether the accelerated formation of more complex lesions, as observed earlier in ApoE3-Leiden mice, may ultimately result in destabilisation of atherosclerotic plaques with an increased risk for plaque rupture. As ApoE3-Leiden mice develop complex atherosclerotic plaques only slowly we decided to used the ApoE, LDL-receptor double knockout strain (ApoE/LDLr-/-), which develops atherosclerosis much faster and studied plaque composition in detail (Chapter 5). Azithromycin has been shown in both human and animal studies to be an effective therapy for reduction of the effects of Cpn on atherosclerosis. By using ApoE/LDLr -/- mice, we evaluated the effect of early treatment with this antibiotic on Cpn-induced alterations in plaque size as well as plaque composition (Chapter 6). Finally, in Chapter 7 the observations as described in this thesis are discussed and related to the hypothesis that Cpn contributes to the progression of atherosclerosis. 


\section{References}

1. Epstein SE, Zhou YF, Zhu J. Infection and atherosclerosis: emerging mechanistic paradigms. Circulation. 1999;100:e20-8.

2. Ross R. Atherosclerosis--an inflammatory disease. N Engl J Med. 1999;340:115-26.

3. Virmani R, Kolodgie FD, Burke AP, Farb A, Schwartz SM. Lessons from sudden coronary death: a comprehensive morphological classification scheme for atherosclerotic lesions. Arterioscler Thromb Vasc Biol. 2000;20:1262-75.

4. Stary HC, Chandler AB, Dinsmore RE, Fuster V, Glagov S, Insull W, Jr., Rosenfeld ME, Schwartz CJ, Wagner WD, Wissler RW. A definition of advanced types of atherosclerotic lesions and a histological classification of atherosclerosis. A report from the Committee on Vascular Lesions of the Council on Arteriosclerosis, American Heart Association. Arterioscler Thromb Vasc Biol. 1995;15:1512-31.

5. Stary HC. Natural history and histological classification of atherosclerotic lesions: an update. Arterioscler Thromb Vasc Biol. 2000;20:1177-8.

6. Ross R, Glomset JA. Atherosclerosis and the arterial smooth muscle cell: Proliferation of smooth muscle is a key event in the genesis of the lesions of atherosclerosis. Science. 1973;180:1332-9.

7. Ross R, Glomset JA. The pathogenesis of atherosclerosis (second of two parts). N Engl J Med. 1976;295:420-5.

8. Ross R. The pathogenesis of atherosclerosis: a perspective for the 1990s. Nature. 1993;362:801-9.

9. Ross R. Atherosclerosis: current understanding of mechanisms and future strategies in therapy. Transplant Proc. 1993;25:2041-3.

10. de Boer OJ, van der Wal AC, Becker AE. Atherosclerosis, inflammation, and infection. J Pathol. 2000;190:237-43.

11. Hansson G. Immune mechanisms in atherorosclerosis. Arterioscler Thromb Vasc Biol. 2001;21:1897-90.

12. Frostegard J, Ulfgren AK, Nyberg P, Hedin U, Swedenborg J, Andersson U, Hansson GK. Cytokine expression in advanced human atherosclerotic plaques: dominance of pro-inflammatory (Th1) and macrophage-stimulating cytokines. Atherosclerosis. 1999;145:33-43.

13. Chattergee S, Ghosh N. Oxidized low density lipoprotein stimulates aortic smooth muscle cell proliferation. Glycobiology. 1996;6:303-311.

14. Berliner J, NAvab M, Fogelman A, Frank J, Demer L, Edwards P, Watson A, Lusis A. Atherosclerosis: basic mechanisms. Oxidation, inflammation and genetics. Circulation. 1995;91:2488-2496.

15. Osler W. Diseases of the arteries. In: Osler W, ed. Modern Medicine: Its Practice and Theory. Philadelphia: Lea and Febiger; 1908:429-447.

16. Frothingham $\mathrm{C}$. The relationship between acute infectious diseases and arterial lesions. Arch Intern Med. 1911;8:153-162.

17. Klotz O, Manning M. Fatty streaks in intima of arteries. J Pathol Bacteriol. 1912;16:211-220.

18. Danesh J, Collins R, Peto R. Chronic infections and coronary heart disease: is there a link? Lancet. 1997;350:430-6.

19. Epstein SE, Zhu J, Burnett MS, Zhou YF, Vercellotti G, Hajjar D. Infection and atherosclerosis: potential roles of pathogen burden and molecular mimicry. Arterioscler Thromb Vasc Biol. 2000;20:1417-20.

20. Epstein SE. The multiple mechanisms by which infection may contribute to atherosclerosis development and course. Circ Res. 2002;90:2-4. 
21. Benditt EP, Benditt JM. Evidence for a monoclonal origin of human atherosclerotic plaques. Proc Natl Acad Sci U S A. 1973;70:1753-6.

22. Fabricant CG, Fabricant J, Litrenta MM, Minick CR. Virus-induced atherosclerosis. J Exp Med. 1978;148:335-40.

23. Blum A, Peleg A, Weinberg M. Anti-cytomegalovirus (CMV) IgG antibody titer in patients with risk factors to atherosclerosis. Clin Exp Med. 2003;3:157-60.

24. Rifkind D, Goodman N, Hill RB, Jr. The clinical significance of cytomegalovirus infection in renal transplant recipients. Ann Intern Med. 1967;66:1116-28.

25. Potena L, Grigioni F, Ortolani P, Magnani G, Marrozzini C, Falchetti E, Barbieri A, BacchiReggiani L, Lazzarotto T, Marzocchi A, Magelli C, Landini MP, Branzi A. Relevance of cytomegalovirus infection and coronary-artery remodeling in the first year after heart transplantation: a prospective three-dimensional intravascular ultrasound study. Transplantation. 2003;75:839-43.

26. Vamvakopoulos J, Hayry P. Cytomegalovirus and transplant arteriopathy: evidence for a link is mounting, but the jury is still out. Transplantation. 2003;75:742-3.

27. Adam E, Melnick JL, Probtsfield JL, Petrie BL, Burek J, Bailey KR, McCollum CH, DeBakey ME. High levels of cytomegalovirus antibody in patients requiring vascular surgery for atherosclerosis. Lancet. 1987;2:291-3.

28. Melnick JL, Adam E, DeBakey ME. Cytomegalovirus and atherosclerosis. Arch Immunol Ther Exp (Warsz). 1996;44:297-302.

29. Melnick JL, Petrie BL, Dreesman GR, Burek J, McCollum CH, DeBakey ME. Cytomegalovirus antigen within human arterial smooth muscle cells. Lancet. 1983;2:644-7.

30. Hendrix MG, Salimans MM, van Boven CP, Bruggeman CA. High prevalence of latently present cytomegalovirus in arterial walls of patients suffering from grade III atherosclerosis. Am J Pathol. 1990;136:23-8.

31. Zhou YF, Leon MB, Waclawiw MA, Popma JJ, Yu ZX, Finkel T, Epstein SE. Association between prior cytomegalovirus infection and the risk of restenosis after coronary atherectomy. N Engl J Med. 1996;335:624-30.

32. Grattan MT, Moreno-Cabral CE, Starnes VA, Oyer PE, Stinson EB, Shumway NE. Cytomegalovirus infection is associated with cardiac allograft rejection and atherosclerosis. Jama. 1989;261:3561-6.

33. Kalil RS, Hudson SL, Gaston RS. Determinants of cardiovascular mortality after renal transplantation: a role for cytomegalovirus? Am J Transplant. 2003;3:79-81.

34. Lemstrom KB, Bruning JH, Bruggeman CA, Lautenschlager IT, Hayry PJ. Cytomegalovirus infection enhances smooth muscle cell proliferation and intimal thickening of rat aortic allografts. J Clin Invest. 1993;92:549-58.

35. Bruning JH, Persoons M, Lemstrom K, Stals FS, De Clercq E, Bruggeman CA. Enhancement of transplantation-associated atherosclerosis by CMV, which can be prevented by antiviral therapy in the form of HPMPC. Transpl Int. 1994;7 Suppl 1:S365-70.

36. Li F, Grauls G, Yin M, Bruggeman CA. Initial endothelial injury and cytomegalovirus infection accelerate the development of allograft arteriosclerosis. Transplant Proc. 1995;27:3552-4.

37. Stassen FR, Vega-Cordova X, Vliegen I, Bruggeman CA. Immune activation following cytomegalovirus infection: More important than direct viral effects in cardiovascular disease? J Clin Virol. 2005.

38. Sorlie PD, Adam E, Melnick SL, Folsom A, Skelton T, Chambless LE, Barnes R, Melnick JL. Cytomegalovirus/herpesvirus and carotid atherosclerosis: the ARIC Study. J Med Virol. 1994;42:33-7. 
39. Vliegen I, Stassen F, Grauls G, Blok R, Bruggeman C. MCMV infection increases early Tlymphocyte influx in atherosclerotic lesions in apoE knockout mice. J Clin Virol. 2002;25 Suppl 2:S159-71.

40. Epstein SE, Zhou YF, Zhu J. Potential role of cytomegalovirus in the pathogenesis of restenosis and atherosclerosis. Am Heart J. 1999;138:S476-8.

41. Nieto FJ, Adam E, Sorlie P, Farzadegan H, Melnick JL, Comstock GW, Szklo M. Cohort study of cytomegalovirus infection as a risk factor for carotid intimal-medial thickening, a measure of subclinical atherosclerosis. Circulation. 1996;94:922-7.

42. Woodhouse PR, Khaw KT, Plummer M, Foley A, Meade TW. Seasonal variations of plasma fibrinogen and factor VII activity in the elderly: winter infections and death from cardiovascular disease. Lancet. 1994;343:435-9.

43. Gurevich VS. Influenza, autoimmunity and atherogenesis. Autoimmun Rev. 2005;4:101-5.

44. Meier CR, Jick SS, Derby LE, Vasilakis C, Jick H. Acute respiratory-tract infections and risk of first-time acute myocardial infarction. Lancet. 1998;351:1467-71.

45. Nichol KL, Margolis KL, Wuorenma J, Von Sternberg T. The efficacy and cost effectiveness of vaccination against influenza among elderly persons living in the community. $\mathrm{N}$ Engl $\mathrm{J}$ Med. 1994;331:778-84.

46. Siscovick DS, Raghunathan TE, Lin D, Weinmann S, Arbogast P, Lemaitre RN, Psaty BM, Alexander R, Cobb LA. Influenza vaccination and the risk of primary cardiac arrest. Am J Epidemiol. 2000;152:674-7.

47. Lavallee P, Perchaud V, Gautier-Bertrand M, Grabli D, Amarenco P. Association between influenza vaccination and reduced risk of brain infarction. Stroke. 2002;33:513-8.

48. Van Lenten BJ, Wagner AC, Nayak DP, Hama S, Navab M, Fogelman AM. High-density lipoprotein loses its anti-inflammatory properties during acute influenza a infection. Circulation. 2001;103:2283-8.

49. Julkunen I, Sareneva T, Pirhonen J, Ronni T, Melen K, Matikainen S. Molecular pathogenesis of influenza A virus infection and virus-induced regulation of cytokine gene expression. Cytokine Growth Factor Rev. 2001;12:171-80.

50. Eldor A, Sela-Donenfeld D, Korner M, Pick M, Resnick-Roguel N, Panet A. Injury models of the vascular endothelium: apoptosis and loss of thromboresistance induced by a viral protein. Haemostasis. 1996;26 Suppl 4:37-45.

51. Naghavi M, Barlas Z, Siadaty S, Naguib S, Madjid M, Casscells W. Association of influenza vaccination and reduced risk of recurrent myocardial infarction. Circulation. 2000;102:3039-45.

52. Nomura A, Stemmermann GN, Chyou PH, Perez-Perez GI, Blaser MJ. Helicobacter pylori infection and the risk for duodenal and gastric ulceration. Ann Intern Med. 1994;120:977-81.

53. Mendall MA, Goggin PM, Molineaux N, Levy J, Toosy T, Strachan D, Camm AJ, Northfield TC. Relation of Helicobacter pylori infection and coronary heart disease. Br Heart J. 1994;71:437-9.

54. Aguejouf O, Mayo K, Monteiro L, Doutremepuich F, Doutremepuich C, Megraud F. Increase of arterial thrombosis parameters in chronic Helicobacter pylori infection in mice. Thromb Res. 2002;108:245-8.

55. Pasceri V, Cammarota G, Patti G, Cuoco L, Gasbarrini A, Grillo RL, Fedeli G, Gasbarrini G, Maseri A. Association of virulent Helicobacter pylori strains with ischemic heart disease. Circulation. 1998;97:1675-9.

56. Corrado E, Rizzo M, Tantillo R, Muratori I, Bonura F, Vitale G, Novo S. Markers of Inflammation and Infection Influence the Outcome of Patients With Baseline Asymptomatic Carotid Lesions. A 5-Year Follow-Up Study. Stroke. 2005. 
57. Franceschi F, Leo D, Fini L, Santoliquido A, Flore R, Tondi P, Roccarina D, Nista EC, Cazzato Al, Lupascu A, Pola P, Silveri NG, Gasbarrini G, Gasbarrini A. Helicobacter pylori infection and ischaemic heart disease: an overview of the general literature. Dig Liver Dis. 2005;37:301-8.

58. Mach F, Sukhova GK, Michetti M, Libby P, Michetti P. Influence of Helicobacter pylori infection during atherogenesis in vivo in mice. Circ Res. 2002;90:E1-4.

59. Danesh J, Peto R. Risk factors for coronary heart disease and infection with Helicobacter pylori: meta-analysis of 18 studies. Bmj. 1998;316:1130-2.

60. Zhu J, Katz RJ, Quyyumi AA, Canos DA, Rott D, Csako G, Zalles-Ganley A, Ogunmakinwa J, Wasserman AG, Epstein SE. Association of serum antibodies to heat-shock protein 65 with coronary calcification levels: suggestion of pathogen-triggered autoimmunity in early atherosclerosis. Circulation. 2004;109:36-41.

61. Amar S, Han X. The impact of periodontal infection on systemic diseases. Med Sci Monit. 2003;9:RA291-9.

62. Valtonen VV. Role of infections in atherosclerosis. Am Heart J. 1999;138:S431-3.

63. Mattila KJ, Valle MS, Nieminen MS, Valtonen VV, Hietaniemi KL. Dental infections and coronary atherosclerosis. Atherosclerosis. 1993;103:205-11.

64. Beck J, Garcia R, Heiss G, Vokonas PS, Offenbacher S. Periodontal disease and cardiovascular disease. J Periodontol. 1996;67:1123-37.

65. Beck JD, Offenbacher S. Systemic effects of periodontitis: epidemiology of periodontal disease and cardiovascular disease. J Periodontol. 2005;76:2089-100.

66. Li L, Messas E, Batista EL, Jr., Levine RA, Amar S. Porphyromonas gingivalis infection accelerates the progression of atherosclerosis in a heterozygous apolipoprotein E-deficient murine model. Circulation. 2002;105:861-7.

67. Lalla E, Lamster IB, Hofmann MA, Bucciarelli L, Jerud AP, Tucker S, Lu Y, Papapanou PN, Schmidt AM. Oral infection with a periodontal pathogen accelerates early atherosclerosis in apolipoprotein E-null mice. Arterioscler Thromb Vasc Biol. 2003;23:1405-11.

68. Desvarieux M, Demmer RT, Rundek T, Boden-Albala B, Jacobs DR, Jr., Papapanou PN, Sacco RL. Relationship between periodontal disease, tooth loss, and carotid artery plaque: the Oral Infections and Vascular Disease Epidemiology Study (INVEST). Stroke. 2003;34:2120-5.

69. Mattila KJ, Pussinen PJ, Paju S. Dental infections and cardiovascular diseases: a review. J Periodontol. 2005;76:2085-8.

70. Fong IW. Infections and their role in atherosclerotic vascular disease. J Am Dent Assoc. 2002;133 Suppl:7S-13S.

71. Kuo CC, Chen HH, Wang SP, Grayston JT. Identification of a new group of Chlamydia psittaci strains called TWAR. J Clin Microbiol. 1986;24:1034-7.

72. Grayston JT, Kuo CC, Wang SP, Altman J. A new Chlamydia psittaci strain, TWAR, isolated in acute respiratory tract infections. N Engl J Med. 1986;315:161-8.

73. Grayston JT, Campbell LA, Kuo CC, Mordhorst CH, Saikku P, Thom DH, Wang SP. A new respiratory tract pathogen: Chlamydia pneumoniae strain TWAR. J Infect Dis. 1990;161:618-25.

74. Everett KD. Chlamydia and Chlamydiales: more than meets the eye. Vet Microbiol. 2000;75:109-26.

75. Rockey DD, Lenart J, Stephens RS. Genome sequencing and our understanding of chlamydiae. Infect Immun. 2000;68:5473-9.

76. Kalman S, Mitchell W, Marathe R, Lammel C, Fan J, Hyman RW, Olinger L, Grimwood J, Davis RW, Stephens RS. Comparative genomes of Chlamydia pneumoniae and C. trachomatis. Nat Genet. 1999;21:385-9. 
77. Beatty WL, Morrison RP, Byrne Gl. Persistent chlamydiae: from cell culture to a paradigm for chlamydial pathogenesis. Microbiol Rev. 1994;58:686-99.

78. Stephens RS, Wagar EA, Schoolnik GK. High-resolution mapping of serovar-specific and common antigenic determinants of the major outer membrane protein of Chlamydia trachomatis. J Exp Med. 1988;167:817-31.

79. Caldwell HD, Kromhout J, Schachter J. Purification and partial characterization of the major outer membrane protein of Chlamydia trachomatis. Infect Immun. 1981;31:1161-76.

80. Hatch TP, Allan I, Pearce JH. Structural and polypeptide differences between envelopes of infective and reproductive life cycle forms of Chlamydia spp. J Bacteriol. 1984;157:13-20.

81. Hammerschlag MR. Pneumonia due to Chlamydia pneumoniae in children: epidemiology, diagnosis, and treatment. Pediatr Pulmonol. 2003;36:384-90.

82. Stratton CW, Sriram S. Association of Chlamydia pneumoniae with central nervous system disease. Microbes Infect. 2003;5:1249-53.

83. Cazzola M, Matera MG, Blasi F. Macrolide and occult infection in asthma. Curr Opin Pulm Med. 2004;10:7-14.

84. Saikku P, Leinonen M, Mattila K, Ekman MR, Nieminen MS, Makela PH, Huttunen JK, Valtonen V. Serological evidence of an association of a novel Chlamydia, TWAR, with chronic coronary heart disease and acute myocardial infarction. Lancet. 1988;2:983-6.

85. Blasi F, Damato S, Cosentini R, Tarsia P, Raccanelli R, Centanni S, Allegra L. Chlamydia pneumoniae and chronic bronchitis: association with severity and bacterial clearance following treatment. Thorax. 2002;57:672-6.

86. Furrows SJ, Hartley JC, Bell J, Silver N, Losseff N, Stevenson S, Chapman M, Thompson EJ, Ridgway GL, Giovannoni G. Chlamydophila pneumoniae infection of the central nervous system in patients with multiple sclerosis. J Neurol Neurosurg Psychiatry. 2004;75:152-4.

87. Hannu T, Puolakkainen M, Leirisalo-Repo M. Chlamydia pneumoniae as a triggering infection in reactive arthritis. Rheumatology (Oxford). 1999;38:411-4.

88. Hammerschlag MR. The intracellular life of chlamydiae. Semin Pediatr Infect Dis. 2002;13:239-48.

89. Grayston JT. Infections caused by Chlamydia pneumoniae strain TWAR. Clin Infect Dis. 1992;15:757-61.

90. Kuo CC, Jackson LA, Campbell LA, Grayston JT. Chlamydia pneumoniae (TWAR). Clin Microbiol Rev. 1995;8:451-61.

91. Aldous MB, Grayston JT, Wang SP, Foy HM. Seroepidemiology of Chlamydia pneumoniae TWAR infection in Seattle families, 1966-1979. J Infect Dis. 1992;166:646-9.

92. Stolk-Engelaar MV, Peeters MF. [Is Chlamydia TWAR of significance in The Netherlands?]. Ned Tijdschr Geneeskd. 1990;134:1094-7.

93. Kanamoto Y, Ouchi K, Mizui M, Ushio M, Usui T. Prevalence of antibody to Chlamydia pneumoniae TWAR in japan. J Clin Microbiol. 1991;29:816-8.

94. Einarsson S, Sigurdsson HK, Magnusdottir SD, Erlendsdottir H, Briem H, Gudmundsson S. Age specific prevalence of antibodies against Chlamydia pneumoniae in Iceland. Scand J Infect Dis. 1994;26:393-7.

95. Karvonen M, Tuomilehto J, Pitkaniemi J, Naukkarinen A, Saikku P. Chlamydia pneumoniae IgG antibody prevalence in south-western and eastern Finland in 1982 and 1987. Int J Epidemiol. 1994;23:176-84.

96. Kleemola M, Saikku P, Visakorpi R, Wang SP, Grayston JT. Epidemics of pneumonia caused by TWAR, a new Chlamydia organism, in military trainees in Finland. $\mathrm{J}$ Infect Dis. 1988;157:230-6. 
97. Murray P, Rosenthal K, Kobayashi G, Phaller M. Orthomyxoviruses. In: Brown M, ed. MEdical Microbiology. fourth ed. St. Louis: Mosby Inc.; 2002:535-542.

98. Kishimoto T, Masashi M, Kubota Y, Miyashita N, Niki Y, Soejima R. An outbreak of Chalmydia pneumoniae infection in households and scholls. In: Orfila J, Byrne G, Chernesky M, eds. Proceedings of the Eight International Symposium on Human Chlamydial Infections: Bologna Societa Editrice Esculapio; 1994:465-468.

99. Mordhorst $\mathrm{CH}$, Wang SP, Grayston JT. Tranmission of Chlamydia pneumoniae (TWAR). In: Orfila J, Byrne GI, Chernesky MA, eds. Proceesings of the Eight International Symposium on Human Chlamydia Infections; 1994:488-491.

100. Ossewaarde JM. Introducing Chlamydophila pneumoniae: the TWAR agent Chlamydia pneumoniae in a new perspective. Neth J Med. 2001;59:41-4.

101. Dowell SF, Peeling RW, Boman J, Carlone GM, Fields BS, Guarner J, Hammerschlag MR, Jackson LA, Kuo CC, Maass M, Messmer TO, Talkington DF, Tondella ML, Zaki SR. Standardizing Chlamydia pneumoniae assays: recommendations from the Centers for Disease Control and Prevention (USA) and the Laboratory Centre for Disease Control (Canada). Clin Infect Dis. 2001;33:492-503.

102. Patnode D, Wang S, Grayston JT. Persistence of Chlamydia pneumoniae, strain TWAR micro-immunofluorescent antibody. In: Orfila J, Byrne GI, Chernesky MA, eds. Proceedings of the Eight International Symposium on Human Chlamydial Infections: Bologna Societa Editrice Esculapio; 1994:407-409.

103. Wong YK, Gallagher PJ, Ward ME. Chlamydia pneumoniae and atherosclerosis. Heart. 1999;81:232-8.

104. Bennedsen M, Berthelsen L, Lind I. Performance of three microimmunofluorescence assays for detection of Chlamydia pneumoniae immunoglobulin $\mathrm{M}, \mathrm{G}$, and $\mathrm{A}$ antibodies. Clin Diagn Lab Immunol. 2002;9:833-9.

105. Peeling RW, Wang SP, Grayston JT, Blasi F, Boman J, Clad A, Freidank H, Gaydos CA, Gnarpe J, Hagiwara T, Jones RB, Orfila J, Persson K, Puolakkainen M, Saikku P, Schachter J. Chlamydia pneumoniae serology: interlaboratory variation in microimmunofluorescence assay results. J Infect Dis. 2000;181 Suppl 3:S426-9.

106. Boman J, Gaydos CA, Quinn TC. Molecular diagnosis of Chlamydia pneumoniae infection. J Clin Microbiol. 1999;37:3791-9.

107. Schweitzer B, Kingsmore S. Combining nucleic acid amplification and detection. Curr Opin Biotechnol. 2001;12:21-7.

108. Boman J, Hammerschlag MR. Chlamydia pneumoniae and atherosclerosis: critical assessment of diagnostic methods and relevance to treatment studies. Clin Microbiol Rev. 2002;15:1-20.

109. Khan MA, Potter CW, Sharrard RM. A reverse transcriptase-PCR based assay for in-vitro antibiotic susceptibility testing of Chlamydia pneumoniae. J Antimicrob Chemother. 1996;37:677-85.

110. Bonanomi A, Dohm C, Rickenbach Z, Altwegg M, Fischer J, Gygi D, Nadal D. Monitoring intracellular replication of Chlamydophila (Chlamydia) pneumoniae in cell cultures and comparing clinical samples by real-time PCR. Diagn Microbiol Infect Dis. 2003;46:39-47.

111. Meijer A, Roholl PJ, Gielis-Proper SK, Meulenberg YF, Ossewaarde JM. Chlamydia pneumoniae in vitro and in vivo: a critical evaluation of in situ detection methods. J Clin Pathol. 2000;53:904-10.

112. Ong G, Thomas BJ, Mansfield AO, Davidson BR, Taylor-Robinson D. Detection and widespread distribution of Chlamydia pneumoniae in the vascular system and its possible implications. J Clin Pathol. 1996;49:102-6. 
113. Shor A, Phillips JI, Ong G, Thomas BJ, Taylor-Robinson D. Chlamydia pneumoniae in atheroma: consideration of criteria for causality. J Clin Pathol. 1998;51:812-7.

114. Danesh J, Whincup P, Walker M, Lennon L, Thomson A, Appleby P, Wong Y, BernardesSilva M, Ward M. Chlamydia pneumoniae IgG titres and coronary heart disease: prospective study and meta-analysis. Bmj. 2000;321:208-13.

115. Vainas T, De Graaf R, Stassen FR, Kurvers HA, Grauls GE, Kitslaar PJ, Bruggeman CA. Chlamydia pneumoniae serology: comparing a commercial enzyme immunoassay and microimmunofluorescence test in patients with cardiovascular disease. Apmis. 2003;111:363-9.

116. Maass M, Bartels C, Engel PM, Mamat U, Sievers HH. Endovascular presence of viable Chlamydia pneumoniae is a common phenomenon in coronary artery disease. J Am Coll Cardiol. 1998;31:827-32.

117. Jackson LA, Campbell LA, Kuo CC, Rodriguez DI, Lee A, Grayston JT. Isolation of Chlamydia pneumoniae from a carotid endarterectomy specimen. J Infect Dis. 1997;176:292-5.

118. Ramirez JA. Isolation of Chlamydia pneumoniae from the coronary artery of a patient with coronary atherosclerosis. The Chlamydia pneumoniae/Atherosclerosis Study Group. Ann Intern Med. 1996;125:979-82.

119. Tompkins LS, Schachter J, Boman J, Chernesky MA, Dowell S, Gaydos CA, Levison ME, Maass M, Madico G, Orfila J, Ouchi K, Peeling RW, Taylor-Robinson D, Stamm WE, Wang SP, Blasi F, Relman D. Collaborative multidisciplinary workshop report: detection, culture, serology, and antimicrobial susceptibility testing of Chlamydia pneumoniae. J Infect Dis. 2000;181 Suppl 3:S460-1.

120. Dalhoff K, Maass M. Chlamydia pneumoniae pneumonia in hospitalized patients. Clinical characteristics and diagnostic value of polymerase chain reaction detection in BAL. Chest. 1996;110:351-6.

121. Bartels C, Maass M, Bein G, Brill N, Bechtel JF, Leyh R, Sievers HH. Association of serology with the endovascular presence of Chlamydia pneumoniae and cytomegalovirus in coronary artery and vein graft disease. Circulation. 2000;101:137-41.

122. Apfalter P, Assadian O, Blasi F, Boman J, Gaydos CA, Kundi M, Makristathis A, Nehr M, Rotter ML, Hirschl AM. Reliability of nested PCR for detection of Chlamydia pneumoniae DNA in atheromas: results from a multicenter study applying standardized protocols. J Clin Microbiol. 2002;40:4428-34.

123. Kuo C, Campbell LA. Detection of Chlamydia pneumoniae in arterial tissues. J Infect Dis. 2000;181 Suppl 3:S432-6.

124. Taylor-Robinson D. Chlamydia pneumoniae in vascular tissue. Atherosclerosis. 1998;140 Suppl 1:S21-4.

125. Jantos CA, Nesseler A, Waas W, Baumgartner W, Tillmanns H, Haberbosch W. Low prevalence of Chlamydia pneumoniae in atherectomy specimens from patients with coronary heart disease. Clin Infect Dis. 1999;28:988-92.

126. Jackson LA, Campbell LA, Schmidt RA, Kuo CC, Cappuccio AL, Lee MJ, Grayston JT. Specificity of detection of Chlamydia pneumoniae in cardiovascular atheroma: evaluation of the innocent bystander hypothesis. Am J Pathol. 1997;150:1785-90.

127. Gupta S, Leatham EW, Carrington D, Mendall MA, Kaski JC, Camm AJ. Elevated Chlamydia pneumoniae antibodies, cardiovascular events, and azithromycin in male survivors of myocardial infarction. Circulation. 1997;96:404-7.

128. Campbell LA, O'Brien ER, Cappuccio AL, Kuo CC, Wang SP, Stewart D, Patton DL, Cummings PK, Grayston JT. Detection of Chlamydia pneumoniae TWAR in human coronary atherectomy tissues. J Infect Dis. 1995;172:585-8. 
129. Liuba P, Karnani P, Pesonen E, Paakkari I, Forslid A, Johansson L, Persson K, Wadstrom $\mathrm{T}$, Laurini R. Endothelial dysfunction after repeated Chlamydia pneumoniae infection in apolipoprotein E-knockout mice. Circulation. 2000;102:1039-44.

130. Coombes BK, Mahony JB. Chlamydia pneumoniae infection of human endothelial cells induces proliferation of smooth muscle cells via an endothelial cell-derived soluble factor(s). Infect Immun. 1999;67:2909-15.

131. Rosenfeld ME, Blessing E, Lin TM, Moazed TC, Campbell LA, Kuo C. Chlamydia, inflammation, and atherogenesis. J Infect Dis. 2000;181 Suppl 3:S492-7.

132. Blessing E, Lin TM, Campbell LA, Rosenfeld ME, Lloyd D, Kuo C. Chlamydia pneumoniae induces inflammatory changes in the heart and aorta of normocholesterolemic C57BL/6J mice. Infect Immun. 2000;68:4765-8.

133. Paigen B, Ishida BY, Verstuyft J, Winters RB, Albee D. Atherosclerosis susceptibility differences among progenitors of recombinant inbred strains of mice. Arteriosclerosis. 1990;10:316-23.

134. Blessing E, Campbell LA, Rosenfeld ME, Chough N, Kuo CC. Chlamydia pneumoniae infection accelerates hyperlipidemia induced atherosclerotic lesion development in C57BL/6J mice. Atherosclerosis. 2001;158:13-7.

135. Blessing E, Campbell L, Rosenfeld M, Kuo C-C. Chlamydia pneumoniae and hyperlipidemia are co-risk factors for atherosclerosis: infection prior to induction of hyperlipidemia does not accelerate development of atherosclerotic leisons in C57BL/6J mice. Infection and Immunity. 2002;70:5332-5334.

136. Hu H, Pierce GN, Zhong G. The atherogenic effects of chlamydia are dependent on serum cholesterol and specific to Chlamydia pneumoniae. J Clin Invest. 1999;103:747-53.

137. Liu L, Hu H, Ji H, Murdin AD, Pierce GN, Zhong G. Chlamydia pneumoniae infection significantly exacerbates aortic atherosclerosis in an LDLR-/- mouse model within six months. Mol Cell Biochem. 2000;215:123-8.

138. Tiirola T, Erkkila L, Laitinen K, Leinonen M, Saikku P, Bloigu A, Jauhiainen M. Effect of acute Chlamydia pneumoniae infection on lipoprotein metabolism in NIH/S mice. Scand $\mathrm{J}$ Clin Lab Invest. 2002;62:477-84.

139. Chesebro BB, Blessing E, Kuo CC, Rosenfeld ME, Puolakkainen M, Campbell LA. Nitric oxide synthase plays a role in Chlamydia pneumoniae-induced atherosclerosis. Cardiovasc Res. 2003;60:170-4.

140. Moazed TC, Campbell LA, Rosenfeld ME, Grayston JT, Kuo CC. Chlamydia pneumoniae infection accelerates the progression of atherosclerosis in apolipoprotein E-deficient mice. J Infect Dis. 1999;180:238-41.

141. Fong IW, Chiu B, Viira E, Jang D, Mahony JB. De Novo induction of atherosclerosis by Chlamydia pneumoniae in a rabbit model. Infect Immun. 1999;67:6048-55.

142. Campbell LA, Blessing E, Rosenfeld M, Lin T, Kuo C. Mouse models of C. pneumoniae infection and atherosclerosis. J Infect Dis. 2000;181 Suppl 3:S508-13.

143. Liuba P, Pesonen E, Paakkari I, Batra S, Andersen L, Forslid A, Yla-Herttuala S, Persson K, Wadstrom T, Wang X, Laurini R. Co-infection with Chlamydia pneumoniae and Helicobacter pylori results in vascular endothelial dysfunction and enhanced VCAM-1 expression in apoE-knockout mice. J Vasc Res. 2003;40:115-22.

144. Rubanyi GM. The role of endothelium in cardiovascular homeostasis and diseases. J Cardiovasc Pharmacol. 1993;22 Suppl 4:S1-14.

145. Ramos CL, Huo Y, Jung U, Ghosh S, Manka DR, Sarembock IJ, Ley K. Direct demonstration of P-selectin- and VCAM-1-dependent mononuclear cell rolling in early atherosclerotic lesions of apolipoprotein E-deficient mice. Circ Res. 1999;84:1237-44. 
146. Liuba P, Pesonen E, Paakkari I, Batra S, Forslid A, Kovanen P, Pentikainen M, Persson K, Sandstrom S. Acute Chlamydia pneumoniae infection causes coronary endothelial dysfunction in pigs. Atherosclerosis. 2003;167:215-22.

147. Quinn TC, Gaydos CA. In vitro infection and pathogenesis of Chlamydia pneumoniae in endovascular cells. Am Heart J. 1999;138:S507-11.

148. Burian K, Hegyesi H, Buzas E, Endresz V, Kis Z, Falus A, Gonczol E. Chlamydophila (Chlamydia) pneumoniae induces histidine decarboxylase production in the mouse lung. Immunol Lett. 2003;89:229-36.

149. Burian K, Berencsi K, Endresz V, Gyulai Z, Valyi-Nagy T, Valyi-Nagy I, Bakay M, Geng Y, Virok D, Kari L, Hajnal-Papp R, Trinchieri G, Gonczol E. Chlamydia pneumoniae exacerbates aortic inflammatory foci caused by murine cytomegalovirus infection in normocholesterolemic mice. Clin Diagn Lab Immunol. 2001;8:1263-6.

150. Laitinen K, Laurila A, Pyhala L, Leinonen M, Saikku P. Chlamydia pneumoniae infection induces inflammatory changes in the aorta of rabbits. Infect Immun. 1997;65:4832-5.

151. Fong I, Chiu B, Viira E, Fong M, Jang D, Mahony JB. Rabbit model for Chlamydia pneumoniae infection. J Clin Microbiol. 1997;35:48-52.

152. Belland RJ, Ouellette SP, Gieffers J, Byrne GI. Chlamydia pneumoniae and atherosclerosis. Cell Microbiol. 2004;6:117-27.

153. Kaul R, Uphoff J, Wiedeman J, Yadlapalli S, Wenman WM. Detection of Chlamydia pneumoniae DNA in CD3+ lymphocytes from healthy blood donors and patients with coronary artery disease. Circulation. 2000;102:2341-6.

154. Moazed TC, Kuo CC, Grayston JT, Campbell LA. Evidence of systemic dissemination of Chlamydia pneumoniae via macrophages in the mouse. J Infect Dis. 1998;177:1322-5.

155. Mahony JB, Coombes BK. Chlamydia pneumoniae and atherosclerosis: does the evidence support a causal or contributory role? FEMS Microbiol Lett. 2001;197:1-9.

156. Gaydos CA. Growth in vascular cells and cytokine production by Chlamydia pneumoniae. J. Infect. Dis. 2000;181:S473-S478.

157. Molestina R, Miller R, Ramirez J, Summersgil J. Infection of human endothelial cells with Chlamydia pneumoniae stimulates transendothelial migration of neutrophils and monocytes. Infect. Immun. 1999;67:1323-1330.

158. Summersgil J, Molestina R, Miller R, Ramirez J. Interactions of Chlamydia pneumoniae with human endothelial cells. J. Infect. Dis. 2000;181:S479-S482.

159. Kol A, Bourcier T, Lichtman A, Libby P. Chlamydial and human heat shock protein 60 s activate human vascular endothelium, smooth muscle cells, and macrophages. J. Clin. Invest. 1999;103:571-577.

160. Coombes BK, Mahony JB. CDNA array analysis of altered gene expression in human endothelial cells in response to Chlamydia pneumoniae infection. Infect. Immun. 2001;69:1420-1427.

161. Gaydos CA, Summersgil J, Sahney N, Ramirez J, Quinn TC. Replication of Chlamydia pneumoniae in vitro in human macrophages, endothelial cells and aortic artery smooth muscle cells. Infect Immun. 2001;69:1420-1427.

162. Rupp J, Hellwig-Burgel T, Wobbe V, Seitzer U, Brandt E, Maass M. Chlamydia pneumoniae infection promotes a proliferative phenotype in the vasculature through Egr-1 activation in vitro and in vivo. Proc Natl Acad Sci U S A. 2005;102:3447-52.

163. Varadhachary AS, Monestier M, Salgame P. Reciprocal induction of IL-10 and IL-12 from macrophages by low-density lipoprotein and its oxidized forms. Cell Immunol. $2001 ; 213: 45-51$. 
164. Nicoletti A, Paulsson G, Caligiuri G, Zhou X, Hansson GK. Induction of neonatal tolerance to oxidized lipoprotein reduces atherosclerosis in ApoE knockout mice. Mol Med. 2000;6:283-90.

165. Hakkinen T, Karkola K, Yla-Herttuala S. Macrophages, smooth muscle cells, endothelial cells, and T-cells express CD40 and CD40L in fatty streaks and more advanced human atherosclerotic lesions. Colocalization with epitopes of oxidized low-density lipoprotein, scavenger receptor, and CD16 (Fc gammaRIII). Virchows Arch. 2000;437:396-405.

166. Mosorin M, Surcel HM, Laurila A, Lehtinen M, Karttunen R, Juvonen J, Paavonen J, Morrison RP, Saikku P, Juvonen T. Detection of Chlamydia pneumoniae-reactive T lymphocytes in human atherosclerotic plaques of carotid artery. Arterioscler Thromb Vasc Biol. 2000;20:1061-7.

167. Haranaga S, Yamaguchi H, Friedman H, Izumi S-I, Yamamoto Y. Chlamydia pneumoniae infects and multiplies in lymphocytes in vitro. Infection and Immunity. 2001;69:7753-7759.

168. Kol A, Sukhova GK, Lichtman AH, Libby P. Chlamydial heat shock protein 60 localizes in human atheroma and regulates macrophage tumor necrosis factor-alpha and matrix metalloproteinase expression. Circulation. 1998;98:300-7.

169. Kalayoglu M, Byrne GI. Induction of macrophage foam cell formation by Chlamydia pneumoniae. J. Infect. Dis. 1998;177:725-729.

170. Mayr M, Metzler B, Kiechl S, Willeit J, Schett G, Xu Q, Wick G. Endothelial cytotoxicity mediated by serum antibodies to heat shock proteins of Escherichia coli and Chlamydia pneumoniae: immune reactions to heat shock proteins as a possible link between infection and atherosclerosis. Circulation. 1999;99:1560-6.

171. Kalayoglu M, Hoernemen B, LaVerda D, Morrison S, Morrison R, Byrne GI. Cellular oxidation of low-density lipoprotein by Chlamydia pneumoniae. J. Infect. Dis. 1999;180:780-790.

172. Vehmaan-Kreula P, Puolakkainen M, Sarvas M, Welgus HG, Kovanen PT. Chlamydia pneumoniae proteins induce secretion of the $92-\mathrm{kDa}$ gelatinase by human monocytederived macrophages. Arterioscler Thromb Vasc Biol. 2001;21:E1-8.

173. Fryer R, Scwobe E, Woods M, Rodgers M. Chlamydia species infect human vascular endothelial cells and induce procoagulant activity. J. Invest. Med. 1997;45:168-174.

174. Dechend R, Maass M, Gieffers J, Dietz R, Scheidereit C, Leutz A, Gulba DC. Chlamydia pneumoniae infection of vascular smooth muscle and endothelial cells activates NFkappaB and induces tissue factor and PAl-1 expression: a potential link to accelerated arteriosclerosis. Circulation. 1999;100:1369-73.

175. Azenabor A, Mahony JB. Generation of reactive oxygen species and formation of membrane lipid peroxides in cells infected with Chlamydia trachomatis. Int. J. Infect. Dis. 2000;4:46-50.

176. Lusis AJ. Atherosclerosis. Nature. 2000;407:233-41.

177. Libby P. Changing concepts of atherogenisis. J. Inter. Med. 2000;247:349-358.

178. Nazzal D, Cantero AV, Therville N, Segui B, Negre-Salvayre A, Thomsen M, Benoist H. Chlamydia pneumoniae Alters Mildly Oxidized Low-Density Lipoprotein-Induced Cell Death in Human Endothelial Cells, Leading to Necrosis Rather Than Apoptosis. J Infect Dis. 2006;193:136-45.

179. de Kruif MD, van Gorp EC, Keller TT, Ossewaarde JM, ten Cate H. Chlamydia pneumoniae infections in mouse models: relevance for atherosclerosis research. Cardiovasc Res. 2005;65:317-27.

180. Muhlestein JB. Antibiotic treatment of atherosclerosis. Curr Opin Lipidol. 2003;14:605-14.

181. Muhlestein JB, Anderson JL, Hammond EH, Zhao L, Trehan S, Schwobe EP, Carlquist JF. Infection with Chlamydia pneumoniae accelerates the development of atherosclerosis and treatment with azithromycin prevents it in a rabbit model. Circulation. 1998;97:633-6. 
182. Fong IW, Chiu B, Viira E, Jang D, Mahony JB. Influence of clarithromycin on early atherosclerotic lesions after Chlamydia pneumoniae infection in a rabbit model. Antimicrob Agents Chemother. 2002;46:2321-6.

183. Fong IW, Chiu B, Viira E, Jang D, Fong MW, Peeling R, Mahony JB. Can an antibiotic (macrolide) prevent Chlamydia pneumoniae-induced atherosclerosis in a rabbit model? Clin Diagn Lab Immunol. 1999;6:891-4.

184. Fong IW. Antibiotics effects in a rabbit model of Chlamydia pneumoniae-induced atherosclerosis. J Infect Dis. 2000;181 Suppl 3:S514-8.

185. Rothstein NM, Quinn TC, Madico G, Gaydos CA, Lowenstein CJ. Effect of azithromycin on murine arteriosclerosis exacerbated by Chlamydia pneumoniae. J Infect Dis. 2001;183:232-238.

186. Blessing E, Campbell LA, Rosenfeld ME, Chesebro B, Kuo CC. A 6 week course of azithromycin treatment has no beneficial effect on atherosclerotic lesion development in apolipoprotein E-deficient mice chronically infected with Chlamydia pneumoniae. J Antimicrob Chemother. 2005;55:1037-40. 


\section{CHAPTER 2}

Short communication: systemic dissemination of Chlamydia pneumoniae after intratracheal and intraperitoneal infection, a study in C57 Black mice

R Ezzahiri, ${ }^{1}$ FRM Stassen, ${ }^{2}$ SB Herngreen, ${ }^{2}$ HAJM Kurvers, ${ }^{1}$ PJEHM Kitslaar, ${ }^{1}$ CA Bruggeman. ${ }^{2}$ Department of Surgery ${ }^{1}$ and Medical Microbiology ${ }^{2}$ of the University Hospital Maastricht, The Netherlands 


\begin{abstract}
Objective: Although infection with Chlamydia pneumoniae (Cpn), a respiratory pathogen, has been associated with several chronic inflammatory diseases, knowledge about the dissemination of the pathogen in its host is scarce. To investigate this, mice were infected with Cpn through different inoculation routes. Dissemination was determined by means of Cpn DNA presence in various organs.

Methods: C57BI/6J mice were inoculated with Cpn intraperitoneally (ip, 5.107 IFU) or intratracheally (it, 105 IFU) and sacrificed at 2, 4, 6, 14, and 28 days post infection to study presence of Cpn DNA in various organs.

Results: Real time Cpn PCR demonstrated that both ip and it Cpn inoculation induces systemic dissemination to lung, bone marrow, spleen and vascular tree. After ip inoculation the vascular tree contains Cpn DNA up till 6 days after inoculation, while after it inoculation significantly lower copy numbers were observed in the vascular tree (ip: $1711 \pm 1563$ Cpn copy numbers vs. it: $264 \pm 256, p<0.05)$.

Conclusion: This study demonstrates that Cpn has the ability to disseminate systemically after both it and ip inoculation. Furthermore, as ip inoculation resulted in a significant higher number of Cpn DNA copies in vascular tissue material, this inoculation route is preferred over it inoculation if you want to study the effect of Cpn on atherosclerosis.
\end{abstract}


Chlamydia pneumoniae ( $\mathrm{Cpn}$ ) is an intracellular replicating pathogen, which causes respiratory infections such as pneumonia, bronchitis and pharyngitis. ${ }^{1}$ The pathogen has also been associated with extrapulmonary chronic inflammatory diseases as arthritis ${ }^{2}$ and atherosclerosis. ${ }^{3}$ Serological evidence of anti-Cpn antibodies in patients with cardiovascular disease ${ }^{3}$ as well as the presence of Cpn DNA in atheromatous plaques ${ }^{4}$ contribute to the alleged role of $\mathrm{Cpn}$ in the process of atherosclerosis.

Nevertheless, although $\mathrm{Cpn}$ has been found frequently in vascular tissue, the exact mechanism by which this pathogen disseminates from the lungs to the vascular wall and as such contributes to atherosclerosis has not been clarified yet. It has been postulated that monocytes or macrophages may take up and transport Cpn to the vascular wall. The mechanism of systemic dissemination to lung, thymus, spleen and abdominal lymph nodes has been studied in $\mathrm{C} 57 \mathrm{BI} / 6 \mathrm{~J}$ mice after intranasal infection with Cpn. ${ }^{5}$ Although intranasal inoculation "mimics" the natural route of Cpn infection, it also has several disadvantages. Intranasal inoculation stimulates sneezing which may lead to less volume of $\mathrm{Cpn}$ in the lungs but it also has the risk of infection of the stomach instead of lungs. Intratracheal (it) inoculation does not have the disadvantages of intranasal inoculation. Therefore, intratracheal $\mathrm{Cpn}$ inoculation might be superior to intranasal infections to study the effect of $\mathrm{Cpn}$ on various pathologies as atherosclerosis. In our previous experiments, ${ }^{6-8}$ we used intraperitoneal inoculation. Alternatively, mice can be infected by intraperitoneal injections, which might be the most exact way with respect to amount of inclusion forming units (IFU) applied to the experimental model. However, no data concerning systemic dissemination for both routes have been published so far. Therefore, to determine which route is superior in dissemination in particular to the vascular wall, we evaluated both inoculation routes and studied the systemic dissemination of Cpn to target organs.

\section{Chlamydia pneumoniae}

Cpn strain TWAR 2043 (ATCC VR-1355) was cultured in Hep-2 cells as previously published.9 Bacterial titres were determined by titration in Hep-2 cells and stained with fluorescein-isothiocyanate-conjugated (FITC) monoclonal antibody RR 402 (Dako, Denmark) directed against elementary bodies of Cpn.

\section{Dissemination study}

To study the dissemination of $\mathrm{Cpn}, 34$ 10-week old C57BL/6J mice were either infected intratracheally (it, $n=16$ ) or intraperitoneally (ip, $n=18$ ) with Cpn. A pilot study was performed to evaluate the exact dose for it inoculation with $\mathrm{Cpn}$. In this study, mice were inoculated with different doses of $\mathrm{Cpn}$ (105-106 IFU). Inoculation of mice with 105 IFU resulted in successful $\mathrm{Cpn}$ infection of the mice as shown by presence of $\mathrm{Cpn}$ DNA in lung tissue of all mice (data not shown). Higher doses of Cpn were lethal and were not used in our study. For ip inoculation 5.107 IFU Cpn was used as shown in previous work of our laboratory. ${ }^{6-8}$ 
Before it inoculation, mice were sedated with a weight-adjusted dose of pentobarbital (Nembutal , Sanofi BV, Maassluis, The Netherlands). Then, a volume of $50 \mu$ sterile PBS containing 105 IFU Cpn was instilled intratracheally via a canule, followed by 0.1 $\mathrm{ml}$ of air. After intratracheal treatment, the mice were kept in an upright position for several minutes to allow sufficient spreading of the fluid throughout the lungs. Ip infection was performed by injection of $100 \mu$ l sterile PBS containing 5.107 IFU Cpn into the abdominal cavity. At sacrifice, 2, 4, 6, 14, and 28 days post inoculation, mice were anesthetized with pentobarbital and blood was collected from the left ventricular apex of the heart. The arterial tree was perfused with phosphate-buffered saline through a catheter placed in the left ventricular apex. Lung, spleen, bone marrow cells, and vascular tree (aortic arch, thoracic and abdominal aorta) were dissected and stored at $70^{\circ} \mathrm{C}$ for Cpn DNA analysis.

\section{Cpn Polymerase Chain Reaction(PCR)}

DNA was extracted from vascular tissue, lung, spleen, and bone marrow with the Wizard Genomic DNA purification kit (Promega, Germany). For detection of Cpn DNA in target organs, the real-time Cpn PCR (ABI Prism 7000) was used. Primers and probes for the detection of $\mathrm{Cpn}$ were based on a variable domain of the ompA gene, VD4: forward primer 5' TCCGCATTGCTCAGCC3' reverse primer 5'AAACAATTTGCATGAAGTCTGAGAA3' and probe 5'-FAM-TAAACTTAACTGCATGGAACCCTTCTTTACTAGG3'-TAMRA. PCR was carried out in 96-well optical reaction plates (Appllied Biosystems, Foster City, CA) with $25 \mu$ total volume, containing: $12.5 \mu \mathrm{l}$ TaqMan Universal Master Mix, ( 2 times concentrated, Applied Biosystems) 300nM of forward primer, $900 \mathrm{nM}$ reverse primer, $200 \mathrm{nM}$ probe, $3.5 \mu \mathrm{l}$ water, and $5 \mu \mathrm{l}$ of the sample $(1 \mu \mathrm{g}$ of DNA). Also, to generate a standard curve, serial dilutions of Cpn strain were used. The concentrations of the dilutions were: 2.5.102, 2.5.103, 2.5.104, 2.5.105, 2.5.106 copies. A negative control, which consisted of reagents only was included. The ABI Prism 7000 SDS Software was used to calculate the Cpn DNA concentrations in the unknown samples using the data from the standard curve. Every sample was measured twice and the mean values were used for analysis.

The probe carried a 5' FAM reporter and a 3' TAMRA quencher group. Thermal cycling started with UNG activation for 2 minutes at $50^{\circ} \mathrm{C}$, followed by HotStarTaq activation during 10 minutes at $95^{\circ} \mathrm{C}$. Thereafter 42 cycles of amplification were run consisting of 15 seconds at $95^{\circ} \mathrm{C}$ and 1 minute at $60^{\circ} \mathrm{C}$.

\section{Statistical analysis}

Differences in copy numbers of Cpn DNA in different target organs were determined by the Mann-Whitney U-test. Data are expressed as mean \pm SEM. A P-value of $<0.05$ was considered statistically significant. 
Systemic dissemination of Cpn

The results of the dissemination profile of $\mathrm{Cpn}$ after ip and it infection, are expressed in figures $1 \mathrm{~A}, \mathrm{~B}, \mathrm{C}, \mathrm{D}$.

Real-time PCR performed on vascular tree material revealed a significant number of Cpn DNA copies after ip inoculation, while in it-inoculated mice Cpn DNA was undetectable or only a limited number of copies were found (figure $1 \mathrm{~A}$ ).

Cpn DNA levels in spleen were high at 2, and 4 days after ip inoculation with the highest copy number found at 2 days post infection. Thereafter, copy number decreased rapidly. In it-inoculated mice low to undetectable Cpn DNA copy numbers were found in spleen tissue (figure 1B).

In bone marrow cells, Cpn DNA copy number was highest after ip inoculation at 2 days post inoculation. After it inoculation Cpn DNA was detected only at 2 days post inoculation, while copy number at other time points was negligible (figure 1C).

Real-time PCR performed on lung samples showed detectable copies of Cpn DNA at every time point post infection. It-infected mice showed, as expected, higher copy numbers with a peak at 4 days post infection. Copy number in ip-inoculated mice was highest at 4 days post inoculation (figure 1D).

Figure 1: A Copies of Cpn DNA detected in vascular tree $(A)$, spleen $(B)$, bone marrow cells $(C)$, and lung $(D), n=3$ at each time point post inoculation, ip: intraperitoneal inoculation, it: intratracheal inoculation, nd: not detected. Data are expressed as mean \pm SEM. * statistically significant difference between intraperitoneal and intratracheal infected mice at the specific days post inoculation $(p<0.05)$
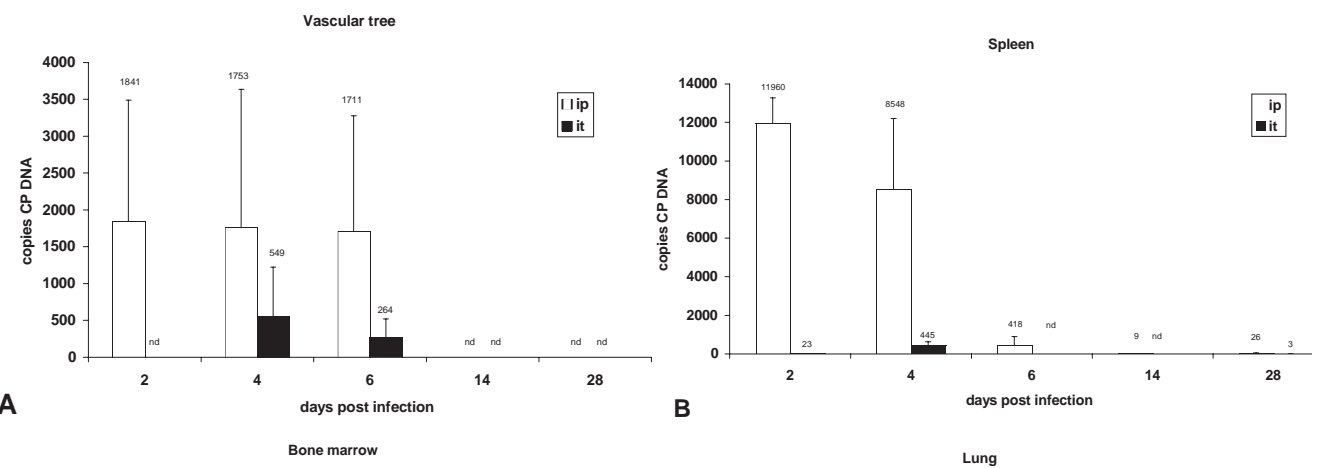

B
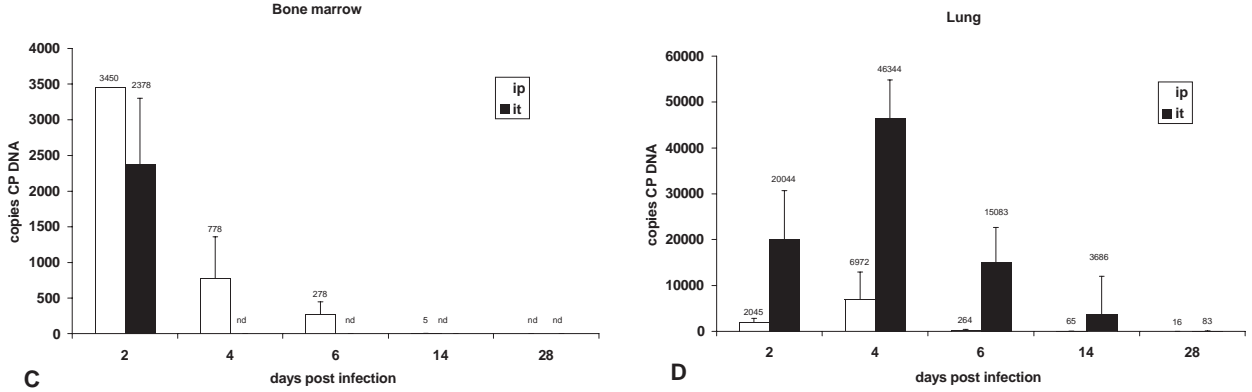
In these experiments we clearly showed that although Cpn is a respiratory pathogen, systemic dissemination is obtained both after intratracheal and intraperitoneal inoculation. In our study we used a quantitive technique (real-time Cpn PCR), which enabled us to quantify Cpn DNA copy numbers while other studies ${ }^{5,10}$ used conventional Cpn PCR which only reports presence of Cpn DNA without information about quantity. In this study, we demonstrated that intraperitoneal Cpn inoculation is the preferred inoculation route to study the effects of Cpn infection on atherogenesis, since by using this inoculation route higher concentrations of $\mathrm{Cpn}$ in the vascular tree are found. Before reaching the vascular wall, Cpn must be transported from the infection site to target organs. Since Cpn elementary bodies have never been detected freely in the circulation, the pathogen must depend on a host cell, possibly (alveolar) monocytes or macrophages, ${ }^{11-13}$ to reach a target organ. In our study, we did not analyse the role of alveolar macrophages after Cpn infection.

Thus, whether alveolar macrophages act as a permanent source of Cpn-infected monocytes or macrophages still remains unclear. Moreover, it is not known whether the same Cpn-infected alveolar macrophage is able to migrate from the lung into the bloodstream and reach the vascular wall. Also, lymphocytes have been reported as a possible vehicle for $\mathrm{Cpn}$, since they are susceptible to $\mathrm{Cpn}$ infection in vitro and invade an atherosclerotic plaque. ${ }^{14-17}$ Besides monocytes, macrophages, and lymphocytes, Cpn has the capacity to multiply in other immune cells as well. Gieffers and coworkers $^{10}$ reported that granulocytes may act as carriers of $\mathrm{Cpn}$ to reach target organs and potentially cause chronic and persistent infections.

In summary, results from this study demonstrate that both intraperitoneal and intratracheal Cpn infection induce systemic dissemination. Intraperitoneal inoculation of Cpn is the preferred inoculation route in mice to study the effect of Cpn infection on atherosclerotic lesion progression, since it is an easy inoculation route to perform and high concentrations of $\mathrm{Cpn}$ in the vascular wall are obtained by this inoculation route. 


\section{References}

1. Grayston JT. Infections caused by Chlamydia pneumoniae strain TWAR. Clin Infect Dis. 1992;15:757-61.

2. Hannu T, Puolakkainen M, Leirisalo-Repo M. Chlamydia pneumoniae as a triggering infection in reactive arthritis. Rheumatology (Oxford). 1999;38:411-4.

3. Saikku P, Leinonen M, Mattila K, Ekman MR, Nieminen MS, Makela PH, Huttunen JK, Valtonen V. Serological evidence of an association of a novel Chlamydia, TWAR, with chronic coronary heart disease and acute myocardial infarction. Lancet. 1988;2:983-6.

4. Ramirez JA. Isolation of Chlamydia pneumoniae from the coronary artery of a patient with coronary atherosclerosis. The Chlamydia pneumoniae/Atherosclerosis Study Group. Ann Intern Med. 1996;125:979-82.

5. Moazed TC, Kuo CC, Grayston JT, Campbell LA. Evidence of systemic dissemination of Chlamydia pneumoniae via macrophages in the mouse. J Infect Dis. 1998;177:1322-5.

6. Ezzahiri R, Nelissen-Vrancken H, Kurvers H, Stassen F, Vliegen I, Grauls G, van Pul M, Kitslaar P, Bruggeman C. Chlamydophila pneumoniae (Chlamydia pneumoniae) accelerates formation of complex atherosclerotic lesion in Apo E3-Leiden mice. Cardiovascular Research. 2002;56:269-76.

7. Ezzahiri R, Stassen F, Kurvers H, van Pul M, Kitslaar P, Bruggeman C. Chlamydia pneumoniae infection induces an unstable atherosclerotic plaque phenotype in LDL-receptor, ApoE double knockout mice. European Journal of Vascular and Endovascular Surgery. 2003;26:88-95.

8. Ezzahiri R, Stassen FR, Kurvers HR, Dolmans V, Kitslaar PJ, Bruggeman CA. Chlamydia pneumoniae infections augment atherosclerotic lesion formation: a role for serum amyloid P. Apmis. 2006;114:117-26.

9. Roblin PM, Dumornay W, Hammerschlag MR. Use of HEp-2 cells for improved isolation and passage of Chlamydia pneumoniae. J Clin Microbiol. 1992;30:1968-71.

10. Gieffers J, van Zandbergen G, Rupp J, Sayk F, Kruger S, Ehlers S, Solbach W, Maass M. Phagocytes transmit Chlamydia pneumoniae from the lungs to the vasculature. Eur Respir J. 2004;23:506-10.

11. Gaydos CA, Summersgill JT, Sahney NN, Ramirez JA, Quinn TC. Replication of Chlamydia pneumoniae in vitro in human macrophages, endothelial cells, and aortic artery smooth muscle cells. Infect Immun. 1996;64:1614-20.

12. Quinn TC, Gaydos CA. In vitro infection and pathogenesis of Chlamydia pneumoniae in endovascular cells. Am Heart J. 1999;138:S507-11.

13. Kalayoglu MV, Byrne GI. A Chlamydia pneumoniae component that induces macrophage foam cell formation is chlamydial lipopolysaccharide. Infect Immun. 1998;66:5067-72.

14. Haranaga S, Yamaguchi H, Friedman H, Izumi S-I, Yamamoto Y. Chlamydia pneumoniae infects and multiplies in lymphocytes in vitro. Infection and Immunity. 2001;69:7753-7759.

15. Kaul R, Uphoff J, Wiedeman J, Yadlapalli S, Wenman WM. Detection of Chlamydia pneumoniae DNA in CD3+ lymphocytes from healthy blood donors and patients with coronary artery disease. Circulation. 2000;102:2341-6.

16. Heinemann M, Susa M, Simnacher U, Marre R, Essig A. Growth of Chlamydia pneumoniae induces cytokine production and expression of CD14 in a human monocytic cell line. Infect Immun. 1996;64:4872-75.

17. Kaukoranta-Tolvanen SS, Teppo A, Laitinen K, Saikku P, Linnavuori K. Growth of Chlamydia pneumoniae in cultured human peripheral blood mononuclear cells and induction of a cytokine response. Microb Pathog. 1996;21:215-21. 


\section{CHAPTER 3}

\section{Chlamydia pneumoniae accelerates formation of complex atherosclerotic lesions in Apo E3-Leiden mice}

R Ezzahiri ${ }^{1}$, HJMG Nelissen-Vrancken², HAJM Kurvers' ${ }^{1}$, FRM Stassen², I Vliegen², GELM Grauls², MML van Pul'1,2,

PJEHM Kitslaar ${ }^{1}$, CA Bruggeman ${ }^{2}$

Department of Surgery ${ }^{1}$ and Medical Microbiology, ${ }^{2}$ Cardiovascular Research Institute Maastricht, Maastricht University, The Netherlands

Cardiovascular Research 2002 nov 56(2): 269-76 


\begin{abstract}
Objective: Atherosclerosis is an inflammatory process and is characterised by presence of T-lymphocytes in the lesions. To study the role of Chlamydophila pneumoniae (C. pneumoniae) in this process and the effect of infection on T-cell influx, we infected Apo E3-Leiden mice with $C$. pneumoniae and investigated the effect on lesion development and T-cell influx in atherosclerotic lesions at different time points post infection (pi).

Methods: Nine week old mice, fed an atherogenic diet, were either mock-infected or infected with $C$. pneumoniae and sacrificed at 1, 6 and 9 months pi. Longitudinal sections of the aortic arches of the mice were stained with hematoxylin-eosin for atherosclerotic lesion type and lesion area analysis, or with rabbit-anti-CD3+ to detect the presence of T-cells in the atherosclerotic lesions. T-cell influx was expressed as number of T-lymphocytes/lesion area.

Results: At 1 month pi, type 1,2 and 3 lesions were present. At other time points pi, more complex lesion types $4,5 \mathrm{a}$ and $5 \mathrm{~b}$ were present as well. Although infection did not influence the total lesion number or area, we observed an effect of $C$. pneumoniae infection on lesion type. Infection resulted in a significant shift in lesion formation from type 3 to type $4(p=0.022)$ at 6 months pi, and from type 4 to type $5 a(p=0.002)$ at 9 months pi. T-cells were observed at every time point pi. At 1 month pi a significant increase in T-cell influx in the $C$. pneumoniae-infected atherosclerotic lesions was observed $(p=0.0005)$.

Conclusion: This study shows that $C$. pneumoniae infection enhances the inflammatory process by the increase of T-lymphocytes in the plaque and accelerates the formation of complex lesions.
\end{abstract}


Cardiovascular complications due to atherosclerosis are the major causes of morbidity and mortality in the Western world. Besides several well known risk factors, such as smoking and hypercholesterolemia, ${ }^{1}$ infections have been suggested to play an important role in the development of atherosclerosis over the last decades. ${ }^{2-4}$ Infectious agents like Cytomegalovirus, Chlamydophila pneumoniae (C. pneumoniae), Helicobacter pylori, and bacteria causing dental infections all have been linked to atherosclerosis. ${ }^{1,5-7}$ For $C$. pneumoniae the association has been demonstrated in sero-epidemiological, experimental, and clinical studies.,8-15 However, the mechanism by which $C$. pneumoniae contributes to atherosclerosis has not been clarified yet. To understand this mechanism, various animal models, mostly rabbits and mice, have been used. ${ }^{11-14,16}$ Progression of atherosclerosis is reported in New Zealand White rabbits, ${ }^{15}$ as well as in low-density lipoprotein receptor (LDLR) knockout mice ${ }^{11}$ inoculated with C. pneumoniae. In all of these studies, the effect of $C$. pneumoniae infection was only documented on lesion size. However, little is known on the effect of infection on the development and/or progression of lesion types. Since lesion type is an important indicator of severity of atherosclerosis, we studied the effect of $C$. pneumoniae infection on the type of atherosclerotic lesions by grading the lesions according to the guidelines of the American Heart Association. ${ }^{17,18}$

In understanding the atherogenicity of $C$. pneumoniae, insight should be gained concerning the ability of this micro-organism to cause local infection and inflammation of the vascular wall as characterised by influx of leukocytes, consisting mainly of monocytes and T-lymphocytes. When T-lymphocytes are activated they can act as a powerful source of pro-atherogenic cytokines thereby contributing to the progression of atherosclerotic lesion formation from fatty streaks into complex atherosclerotic plaques..$^{19}$ Immunohistochemical studies have demonstrated the presence of T-lymphocytes in human ${ }^{20,21}$ and animal ${ }^{22}$ atherosclerotic plaques. Activation of T-lymphocytes in the plaque can be established by antigens like ox-LDL. ${ }^{23-25}$ However, C. pneumoniae has also proven to be a good candidate for activating T-cells cultured from peripheral blood of patients with atherosclerosis as well as T-cells cultured from carotid endarterectomy tissue. ${ }^{20}$ Recently it has even been demonstrated that $C$. pneumoniae can infect lymphocytes of human peripheral blood and mouse spleens as well as a T-lymphocyte cell line. ${ }^{26}$

In this study, the role of $C$. pneumoniae in atherosclerotic lesion progression was studied using Apo E3-Leiden mice. Mice were infected with C. pneumoniae and sacrificed at different time points post infection (pi) to analyse lesion progression in the aortic arch and main branchpoints. To understand the possible mechanism by which $C$. pneumoniae accelerates atherosclerotic lesion progression, we studied inflammation of the vascular wall by determining the influx of T-lymphocytes in the atherosclerotic lesion.

\section{Materials and methods}

Mice

Sixty-four transgenic Apo E3-Leiden mice on a C57BI/6J background were bred at the Central Animal Facility at the Maastricht University. ${ }^{27}$ For the study, both males and 
females were used and randomly divided over all groups. All mice were specificpathogen-free (SPF) and were housed under standard conditions. This study was approved by the institutional committee for the welfare of laboratory animals of the Maastricht University.

\section{C. pneumoniae}

C. pneumoniae strain TWAR 2043 (ATCC VR-1355) was cultured in HEp-2 cells as previously described. ${ }^{28}$ Bacterial titers were determined by titration in HEp-2 cells and staining with monoclonal antibody RR 402 (Dako, Glostrup, Denmark) followed by fluorescein-isothiocyanate (FITC) conjugated rabbit-anti-mouse (Dako, Glostrup, Denmark). Titers were expressed as inclusion forming units per milliliter (IFU/ml).

\section{Experimental design}

At the age of 5 weeks, the mice received a high-fat cholesterol (HFC) diet containing $15 \%$ cacao butter, $0.5 \%$ cholate, $1 \%$ cholesterol, $40.5 \%$ sucrose, $10 \%$ corn starch, $1 \%$ corn oil, and $4.7 \%$ cellulose (Hopefarms BV, Woerden, The Netherlands). Since it has been demonstrated that multiple infections, the age of the animals at the time of inoculation and the interval between inoculations are all critical factors in mice for enabling C. pneumoniae to promote atherosclerosis, ${ }^{11,14,29,30}$ we decided to inoculate our mice twice with $C$. pneumoniae using different time intervals between inoculations. By infecting the mice for the second time at different time points after the primary infection we also aimed to study the effect of $C$. pneumoniae either on early lesions or more advanced lesions. All mice received the first infection by intraperitoneal injection of $C$. pneumoniae $6.10^{7} \mathrm{IFU}$ at the age of 9 weeks (figure 1). Control mice were injected with sterile phosphate-buffered saline (PBS, mock infection). Since no differences in dissemination of $C$. pneumoniae after intraperitoneal or intranasal inoculation have been reported, ${ }^{31}$ we selected intraperitoneal infection in our mice. In group 1, mice received a second inoculation at the age of 11 weeks and were sacrificed at the age of 13 weeks, 1 month after the first infection (figure 1).

Figure 1: Design of animal experiment, showing the different mice groups analysed in this study, the inoculation time points and time points of sacrifice.

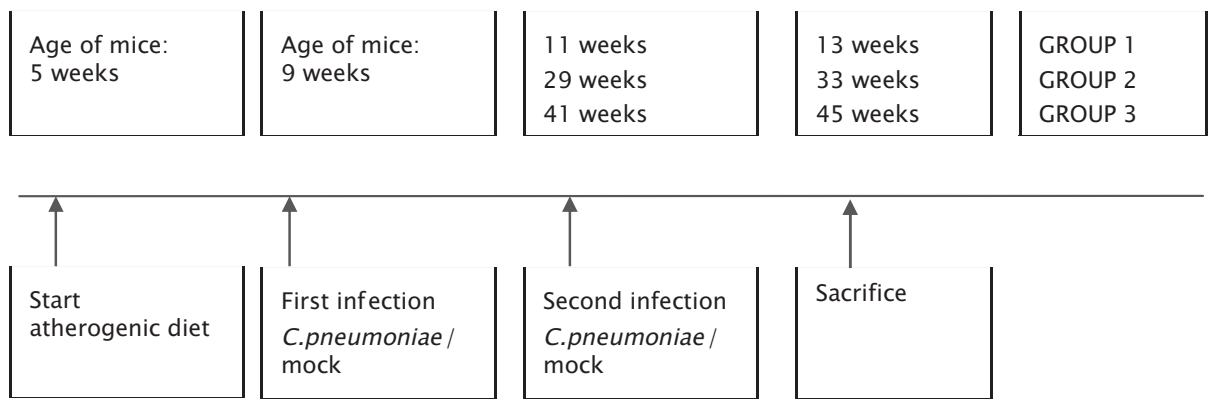


At this time point type 2 lesions are the predominant phenotype in the aortic $\operatorname{arch}^{18}$. In group 2, mice were inoculated for the second time at the age of 29 weeks and were sacrificed at the age of 33 weeks, 6 months after the first infection when type 4 and $5 a$ lesions are present in the aortic $\operatorname{arch}^{18}$. Finally, mice in group 3 received a second inoculation at the age of 41 weeks and were sacrificed at the age of 45 weeks, 9 months after the first infection with calcified type 5 b lesions most prominent ${ }^{18}$.

\section{Tissue handling}

At sacrifice, the mice were anesthetized with a weight-adjusted dose of pentobarbital ${ }^{32}$ (Nembutal , Sanofi Sante BV, Maassluis, The Netherlands) and blood was collected from the left ventricular apex for assessment of lipid profiles and anti-C. pneumoniae antibody titers. The arterial tree was perfused with PBS followed by $1.85 \%$ PBSbuffered formaldehyde, both containing $0.1 \mathrm{mg} / \mathrm{ml}$ sodium-nitroprusside (Merck, Darmstadt, Germany), through a catheter placed in the left ventricular apex. The arterial tree was removed, fixed overnight in 3.7\% PBS-buffered formaldehyde and embedded in paraffin. Four $\mu \mathrm{m}$ thick longitudinal sections were consecutively cut, stained and analysed. ${ }^{18}$

\section{Evaluation of atherosclerotic lesions}

Since all lesion types were found in the aortic arch, ${ }^{18}$ lesion analysis was restricted to this segment of the arterial tree. Only aortic arches with an intact morphology (brachiocephalic trunk, left and right common carotid artery and left subclavian artery) were used.

Of the entire arch, longitudinal, coronal, consecutive sections were made. Every fifth section was hematoxylin-eosin (HE) stained to evaluate lesion type, size and number. Since atherosclerotic lesion development progresses over time thereby increasing the size of he aortic arch, more sections were collected from the aortic arches of group 2 (33 weeks of age) and 3 ( 45 weeks of age) than from arches of group 1 (13 weeks of age). Five HE-stained sections from each aortic arch were analysed in group 1, while in group 2 and 3,11-15 sections per aortic arch were analysed. The type of atherosclerotic lesions was determined according to the guidelines of the American Heart Association (table 1). ${ }^{17}$ The size of the lesions was determined using a microscope coupled to a computer-assisted morphometry system (Quantimet 570, Leica, The Netherlands). For every lesion, the mean area was calculated and total lesion area was calculated as the sum of all mean areas. All sections were analysed by impartial investigators (interobserver variability $<10 \%$ ), who were blinded with respect to the presence or absence of $C$. pneumoniae infection as well as to the time point of sacrifice.

Detection and evaluation of T-lymphocytes in atherosclerotic lesion In order to detect T-lymphocytes in the atherosclerotic lesions, a rabbit-anti-CD3+ polyclonal antibody was used (Dako, Glostrup, Denmark). After a blocking step with Bovine Serum Albumin (BSA)/PBS $2 \%$ for aspecific binding, slides were incubated with the $\mathrm{CD}^{+}$polyclonal antibody for 60 minutes at a dilution of $1: 200$, followed by a second- 
step incubation with a biotinylated swine-anti-rabbit IgG (1:1000, Dako, Glostrup, Denmark) for 30 minutes. Sections were then labelled with an alkaline phosphatase coupled ABC reagent (Dako, Denmark) for 30 minutes. Alkaline phosphatase activity was visualised using Fast-red (Sigma Chemical Co, St. Louis, United States). Rabbitanti-rat IgG (Dako, Glostrup, Denmark) was used as a negative control. For positive controls, tissue sections from mice spleens were used. T-lymphocytes in the atherosclerotic lesion were counted and expressed as the number of T-lymphocytes in the plaque divided by the total plaque area. The investigator was blinded for the presence or absence of $C$. pneumoniae infection as well as to the time point of sacrifice.

Table 1: Classification of atherosclerotic lesion types according to the Stary classification defined in 1995

\begin{tabular}{|c|c|c|c|}
\hline $\begin{array}{l}\text { Lesion } \\
\text { type }\end{array}$ & Nomenclature & Main histology & \\
\hline Type I & Initial lesion & $\begin{array}{l}\text { Isolated macrophage foam cells, adaptive } \\
\text { thickening intima (smooth muscle cells) }\end{array}$ & Early lesions \\
\hline Type II & Fatty streak & Intracellular lipid accumulation & \\
\hline Type III & Intermediate lesion & $\begin{array}{l}\text { Type II changes with small extracellular lipid } \\
\text { pools }\end{array}$ & \\
\hline Type IV & Atheroma & Type II changes with lipid core & \\
\hline Type V & Fibroatheroma & $\begin{array}{l}\text { Fibrotic cap surrounding a lipid core with fibrous } \\
\text { tissue and lipids }(V a) \text {, calcifications }(V b) \text {, or } \\
\text { fibrous component }(V c)\end{array}$ & $\begin{array}{l}\text { Advanced } \\
\text { lesions }\end{array}$ \\
\hline Type VI & Complicated lesion & $\begin{array}{l}\text { Cap disruption, hematoma -hemorrhage, } \\
\text { thrombus }\end{array}$ & \\
\hline
\end{tabular}

Detection of C. pneumoniae antigens and anti-C. pneumoniae antibodies In order to detect $\mathrm{C}$. pneumoniae antigens, a Chlamydia genus-specific mouse monoclonal antibody, CF-2 (Washington Research Foundation, Seattle, Washington, USA) was used. ${ }^{33}$ This monoclonal is directed against chlamydial lipopolysacharide. For each mouse, a representative section with the highest lesion number and the most advanced lesion type, as analysed by the HE staining, was used for $C$. pneumoniae detection. The primary antibody was probed with goat-anti-mouse IgG conjugated with peroxidase (M.O.M.T Kit, Vector, Brunschwig, Amsterdam, The Netherlands). To visualise the antibody binding, 3,3'-diaminobenzodine (DAB, Sigma Chemical Co, St. Louis, United States) was used. Normal mouse ascitic fluid (Sigma-Aldrich Chemie BV, Zwijndrecht, The Netherlands) was used as negative control. Tissue sections from mock-infected mice were used as controls. For positive controls, sections of C. pneumoniae-infected HEp-2 cells were used which were embedded in agarose, fixed overnight in 3.7\% PBS-buffered formaldehyde and embedded in paraffin. 
Anti-C. pneumoniae antibodies were measured with the indirect micro-immunofluorescence (MIF) technique using mouse plasma sample dilutions 1:10 and 1:100 on antigen-coated slides (Labsystems, Helsinki, Finland). Goat-anti-mouse IgG conjugated to FITC (Dako, Glostrup, Denmark) was used as the secondary antibody. The presence of anti-C. pneumoniae antibodies was determined by 2 independent observers.

\section{Assessment of lipid profile}

Total plasma cholesterol and triglyceride concentrations were determined by a standard cholesterol oxidase method performed on Beckman Synchron CX Systems. ${ }^{12}$

\section{Statistical analysis}

The difference in lesion type between the $C$. pneumoniae and mock group was compared and analysed with the Chi-square test. Differences in lesion number and size were analysed with the Mann-Whitney $U$ test. To determine differences in T-cell influx in the lesions the Mann-Whitney $U$ test was used. Plasma lipids of $C$. pneumoniaeand mock-infected groups were compared with the Student's 2-tailed t test. A P-value of $<0.05$ was considered statistically significant. Data are expressed as mean \pm SEM.

\section{Results}

To investigate the effect of $C$. pneumoniae infection on atherosclerotic lesion type, number and total lesion size, sixty-four Apo E3-Leiden mice were infected, sacrificed and analysed. Seven mice died before reaching point of sacrifice, leaving fifty-seven mice for analysis. The cause of death was unknown.

\section{C. pneumoniae infection leads to more severe atherosclerotic lesions}

In the $C$. pneumoniae-infected group as well as in the mock-infected group atherosclerotic lesions were found. The type of lesion was analysed according to the histology criteria expressed in table 1, which are based on the Stary classification defined in $1995 .{ }^{17}$

At 1 month pi, type 1, 2 and 3 lesions were found. The more advanced lesion types $4,5 \mathrm{a}$ and $5 \mathrm{~b}$, were present at 6 and 9 months pi and consisted of a fibrous cap surrounding a necrotic central core. The presence of these lesion types at these time points is in agreement with previous report. ${ }^{18}$ Type 6 lesions were never observed in any of the mice at any given time point pi.

The effect of $C$. pneumoniae infection on atherosclerotic lesion types is presented in table 2. The complexity of the atherosclerotic lesion types increases in time when lesion types of 1 month pi were compared to lesion types of 6 and 9 months pi. At 6 months pi, all lesion types, except type 1 lesions, were present, while at 9 months pi, type 1 and 2 lesions were absent. When the distribution of the lesion types in the $C$. pneumoniae-infected and mock-infected group was analysed, a significant shift in lesion type was observed from type 3 to type 4 at 6 months pi ( $p<0.05$, figure 2), while at 9 months pi, a significant shift was seen from type 4 to type $5 a(p<0.01$, figure 3 ). 
Table 2: Atherosclerotic lesion types in C. pneumoniae- and mock-infected mice. a Presence of mean number of lesions of each type is expressed as the mean frequency \pm SEM. pi post infection, * statistical significant shift from type 3 to type $4(p=0.022),{ }^{* *}$ statistical significant shift from type 4 to type $5 a(p=0.002)$, -lesion type is not present.Total lesion area (right) in C. pneumoniae- and mock-infected group at different time points pi.

\begin{tabular}{|c|c|c|c|c|c|c|c|}
\hline \multirow{2}{*}{$\begin{array}{l}\text { Inoculation } \\
\text { (number of mice) }\end{array}$} & \multicolumn{6}{|c|}{ Lesion type a } & \multirow{2}{*}{$\begin{array}{l}\text { Lesion area } \\
\left(\mathrm{mm}^{2}\right)\end{array}$} \\
\hline & 1 & 2 & 3 & 4 & $5 a$ & $5 b$ & \\
\hline C. pneumoniae (8) & $0.38 \pm 0.18$ & $2.13 \pm 0.79$ & $2.00 \pm 0.57$ & -- & -- & -- & $122 \pm 9$ \\
\hline mock $(8)$ & $0.25 \pm 0.17$ & $0.75 \pm 0.34$ & $1.50 \pm 0.45$ & -- & -- & -- & $81 \pm 6$ \\
\hline C. pneumoniae (7) & -- & $0.14 \pm 0.15$ & $1.71 \pm 0.56$ & $2.86 \pm 0.98^{\star}$ & $1.57 \pm 0.40$ & $1.86 \pm 0.28$ & $969 \pm 29$ \\
\hline $\operatorname{mock}(7)$ & -- & $0 . .43 \pm 0.32$ & $3.14 \pm 0.68^{*}$ & $1.29 \pm 0.39$ & $1.29 \pm 0.20$ & $1.43 \pm 0.22$ & $933 \pm 34$ \\
\hline C. pneumoniae (6) & -- & -- & $0.83 \pm 0.44$ & $0.83 \pm 0.18$ & $3.08 \pm 0.92^{* *}$ & $2.00 \pm 0.69$ & $1802 \pm 85$ \\
\hline mock $(8)$ & -- & -- & $0.63 \pm 0.40$ & $2.63 \pm 0.53^{* *}$ & $1.88 \pm 0.32$ & $2.13 \pm 0.24$ & $1860 \pm 105$ \\
\hline
\end{tabular}

Figure 2: Lesion types in the C. pneumoniae and mock group 6 months post infection. The values are presented as the mean frequency \pm SEM at which that type of lesion was present. ${ }^{*} p=0.022$

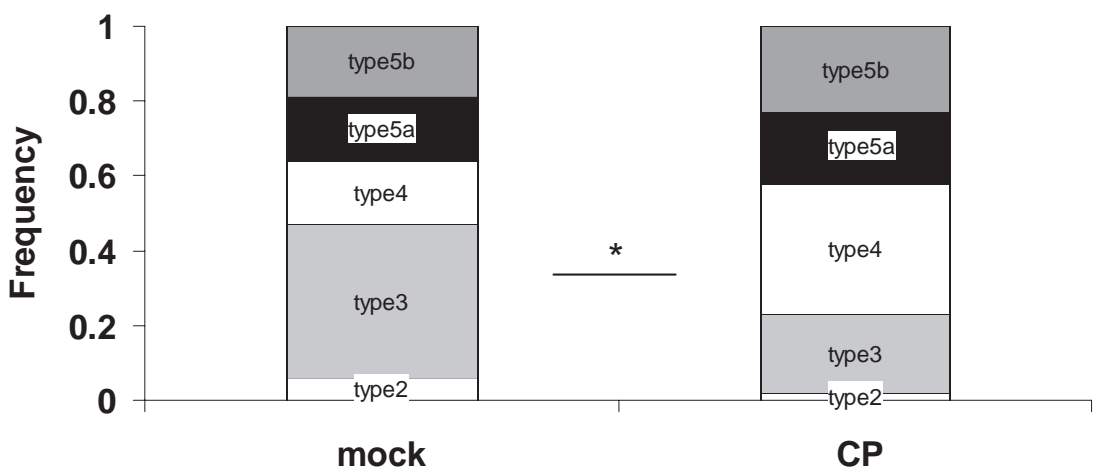

Figure 3: Lesion types in the C. pneumoniae and mock group 9 months post infection. The values are presented as the mean frequency \pm SEM at which that type of lesion was present. ${ }^{*} p=0.002$

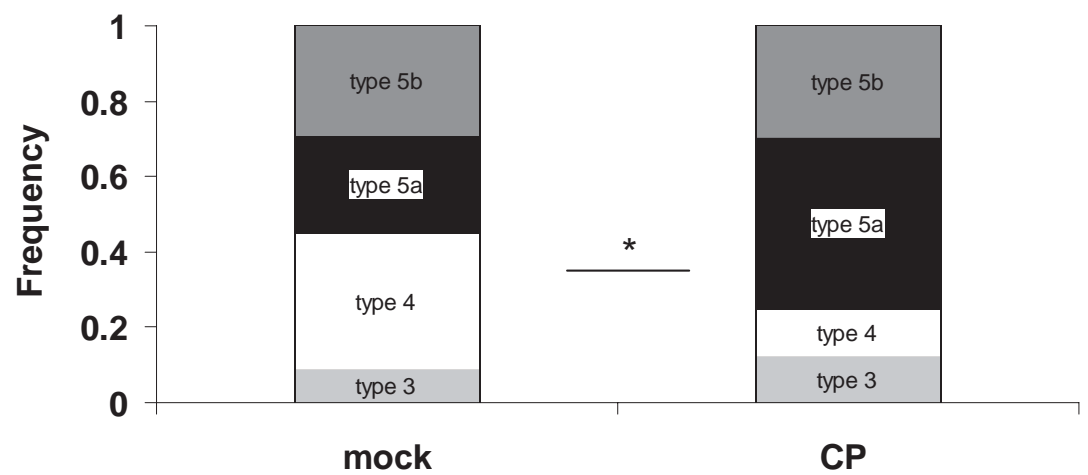


C. pneumoniae infection has no effect on lesion size and number of lesions

The HE-stained sections used for classification of atherosclerotic lesion types were also used for determination of lesion area and number of lesions. Data on the total lesion area are presented in table 2. No statistically significant differences in lesion area could be detected when the $C$. pneumoniae-infected and mock-infected group were compared at the different time points.

The number of atherosclerotic lesions was analysed in all HE-stained sections. The number of lesions in the $C$. pneumoniae-infected and mock-infected group, at the different time points pi, was calculated. Data on lesion number are presented in table 3. There were no significant differences in total lesion number between $C$. pneumoniaeinfected and mock-infected mice at any time point pi.

Table 3: Total lesion number in C. pneumoniae- and mock-infected group at different time points pi. Data are expressed as mean \pm SEM.

\begin{tabular}{|c|c|c|}
\hline Time pi & $\begin{array}{c}\text { Inoculation } \\
\text { (number of mice) }\end{array}$ & lesion number \\
\hline \multirow[t]{2}{*}{1 month } & C. pneumoniae (8) & $4.38 \pm 0.88$ \\
\hline & mock & $2.75 \pm 0.75$ \\
\hline \multirow[t]{2}{*}{6 months } & C. pneumoniae (7) & $8.57 \pm 0.85$ \\
\hline & mock & $8.00 \pm 0.88$ \\
\hline \multirow[t]{2}{*}{9 months } & C. pneumoniae (6) & $6.67 \pm 1.01$ \\
\hline & mock & $7.25 \pm 0.75$ \\
\hline
\end{tabular}

Table 4: Cholesterol and triglyceride levels in C. pneumoniae- and mock-infected group at different time points pi. Data are expressed as mean \pm SEM.

\begin{tabular}{|c|c|c|c|}
\hline Time pi & $\begin{array}{c}\text { Inoculation } \\
\text { (number of mice) }\end{array}$ & $\begin{array}{c}\text { Cholesterol } \\
\mathrm{mmol} / \mathrm{l}\end{array}$ & $\begin{array}{c}\text { Triglycerides } \\
\mathrm{mmol} / \mathrm{l}\end{array}$ \\
\hline \multirow[t]{2}{*}{1 month } & C. pneumoniae (8) & $2.47 \pm 0.73$ & $4.85 \pm 1.65$ \\
\hline & mock & $2,93 \pm 0.63$ & $5.15 \pm 1.41$ \\
\hline \multirow[t]{2}{*}{6 months } & C. pneumoniae (7) & $3.69 \pm 1.00$ & $4.83 \pm 0.97$ \\
\hline & mock & $6.87 \pm 3.30$ & $2.90 \pm 0.80$ \\
\hline \multirow[t]{2}{*}{9 months } & C. pneumoniae (6) & $4.58 \pm 1.17$ & $6.76 \pm 1.90$ \\
\hline & mock & $6.83 \pm 2.73$ & $4.92 \pm 1.44$ \\
\hline
\end{tabular}


Figure 4: Number of T-cells in atherosclerotic lesions at 1 month pi. Data are presented as number of T-cells divided by total plaque area. ${ }^{*} p=0.0005$

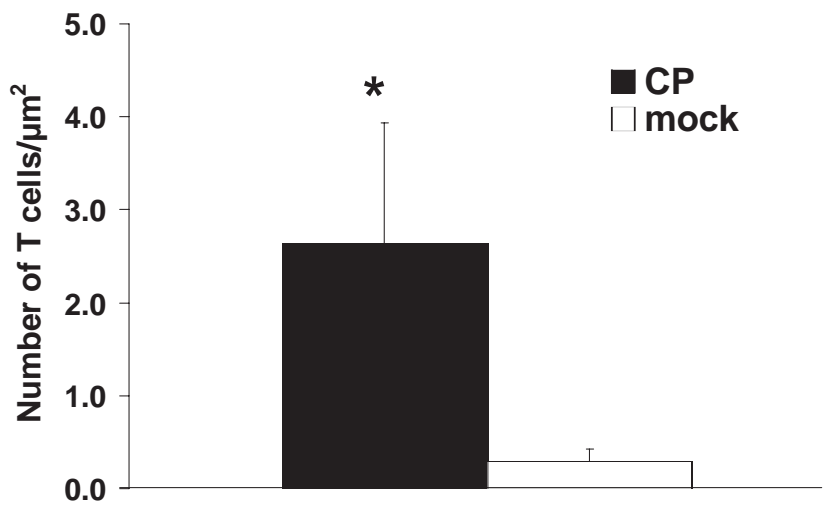

Figure 5: $(A, B)$ T-lymphocyte staining showing positive cells (arrows) in atherosclerotic lesion of $C$. pneumoniae-infected mouse, 1 month pi. Magnification 100x (A) and 400x (B) (C) Chlamydia pneumoniae staining. Chlamydia pneumoniae was detected in a type 3 lesion of an infected mouse, 1 month post infection. Staining is concentrated in the subendothelial layer of the atherosclerotic lesion (see arrows). Magnification 200x.
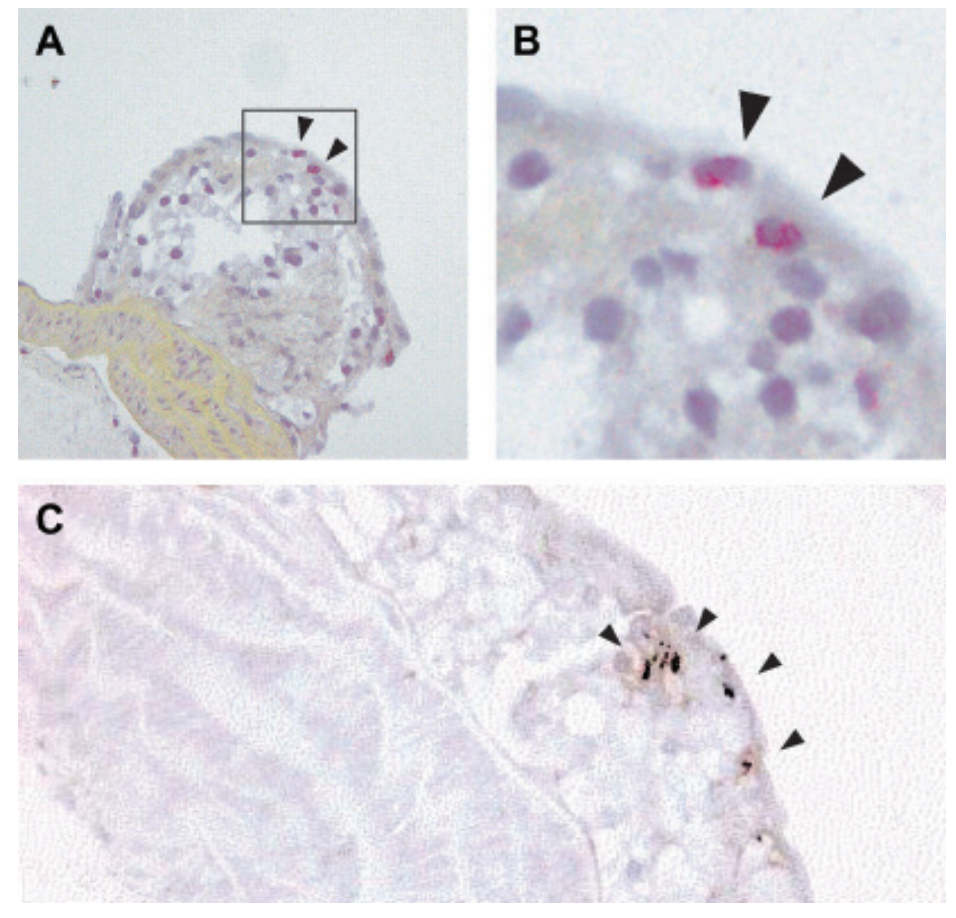
C. pneumoniae infection results in an increased T-cell influx in the atherosclerotic lesions

The effect of $C$. pneumoniae infection on the influx of T-cells was determined at every time point pi in atherosclerotic lesions of the $C$. pneumoniae-infected mice and the mock-infected mice (figure 4). More specifically, at 1 month pi a significant increase in T-cell influx in the $C$. pneumoniae-infected atherosclerotic lesions was observed. Infection resulted in a significant increase in T-cells from $0.29 \mathrm{cells} / \mathrm{m}^{2}$ in the mock group to 2.63 cells $/ \mathrm{m}^{2}$ in the $C$. pneumoniae group ( $p=0.0005$, figure 5). At 6 and 9 months pi no effect of $C$. pneumoniae infection on the influx of T-cells was observed.

\section{Lipid profiles}

At 1, 6 and 9 months pi blood was collected from C. pneumoniae- and mock-infected mice for determination of plasma cholesterol and triglyceride levels. When the $C$. pneumoniae and the mock groups, within one time point pi, were compared, no statistically significant difference was found in cholesterol and triglyceride plasma levels, suggesting that $C$. pneumoniae infection does not affect plasma lipid levels in the long run (data not shown).

C. pneumoniae infection

All C. pneumoniae-infected mice seroconverted after inoculations with C. pneumoni$a e$, indicating that all our inoculated mice had indeed been successfully infected. In all these mice anti- $C$. pneumoniae antibodies were found at plasma dilutions of 1:10 and 1:100. No anti-C. pneumoniae antibodies were detected in plasma of mock-infected mice.

C. pneumoniae antigen was detected by immunohistochemistry staining in about $30 \%$ of the aortic arches of the infected animals at the time points 1,6 and 9 months pi. C. pneumoniae antigen was mainly found in the subendothelial layer of the atherosclerotic lesions of these mice as shown in figure $5 \mathrm{c}$. Since the percentage of positive $C$. pneumoniae antigen was equally divided over all lesion types, no preference of $C$. pneumoniae antigen for a specific atherosclerotic lesion type was observed (data not shown). As expected, mock-infected mice were all negative.

\section{Discussion}

Infection with $C$. pneumoniae has been associated with the process of atherosclerosis, ${ }^{4,9}$ but whether infection influences the initiation or progression of atherosclerosis, or whether it plays a role in plaque (in)stability, has not been clarified yet. Most previously published experimental studies on $C$. pneumoniae infections have reported on the effect of infection on atherosclerotic lesion size. ${ }^{11,14,15,29}$ Nonetheless, no reports on the effect of $C$. pneumoniae infection on lesion type have been published yet. Since the type of atherosclerotic lesions may be a more important indicator for morbidity and mortality than lesion size or number, we evaluated the incidence of different 
atherosclerotic lesion types. In this study we demonstrate that $C$. pneumoniae infection leads to an accelerated formation of complex atherosclerotic lesions. At 6 and 9 months pi, an acceleration in lesion type development was seen, whereas at 1 month pi, no effect of $C$. pneumoniae infection on early lesion formation was observed. This is an intriguing finding as it contributes to the suggestion that $C$. pneumoniae infection may promote progression ${ }^{11,14-16,29}$ of the atherosclerotic process rather than its initiation. $^{33}$ The effect of $C$. pneumoniae on the lesion formation seems to be the result of a long standing process since its effect is only found on later time points, 6 and 9 months pi. This suggests that an antigen-specific immune activation early after infection may contribute to the progression of atherosclerosis. ${ }^{1,6,9}$ Since $C$. pneumoniae has been shown to infect macrophages and use them as a transport vehicle for dissemination ${ }^{31}$ it may be speculated that $C$. pneumoniae enters the vascular wall in this way. Once entered the vascular wall $C$. pneumoniae-infected macrophages may act as antigen-presenting cells thereby attracting T-cells. Indeed, in the present study we demonstrated a marked enhanced T-cell influx shortly after the first infection. Since activated T-cells are a powerful source of pro-atherogenic and pro-inflammatory cytokines, such as IFN- $\gamma$, IL-2 and TNF- $\alpha,{ }^{34}$ this may explain the observed acceleration of plaque development in the long run. On the other hand, T-cells themself may also function as a transport vehicle for $C$. pneumoniae. Recently it has been shown that $C$. pneumoniae can infect and multiply in T-cells. ${ }^{26}$ Furthermore, a significant higher proportion of $C$. pneumoniae positive T-cells were observed in patients with coronary artery disease compared to healthy blood donors. ${ }^{35}$ Future co-localisation studies may shed some light on where $C$. pneumoniae is exactly located in the vascular wall of our infected mice.

Besides atherosclerotic lesion type, we also determined the effect of $C$. pneumoniae infection on lesion size and number and found no difference between the $\mathrm{C}$. pneumoniae- and mock-infected mice. This corresponds to findings in previous studies, who also did not find any effect of $C$. pneumoniae infection on lesion size. ${ }^{36,37}$ In contrast, other studies reporting an increase in lesion size after infection with $C$. pneumoniae have been published as well. ${ }^{11,14}$ The difference between other studies and ours may result from differences in $C$. pneumoniae strain, inoculation schedule or type of animal model used. LDLR knockout ${ }^{11}$ and Apo $E$ knockout mice ${ }^{14,36,37}$ are the mice strains used by other groups. In the present study Apo E3-Leiden mice were used..$^{18}$ It is known that different mouse strains vary in susceptibility to $C$. pneumoniae infection and the formation of atherosclerotic lesions. ${ }^{38}$ Of the latter studies, only one reports of elevated lipid levels after $C$. pneumoniae infection in LDLR knockout mice. ${ }^{11}$ However, in the present study and in previous reports ${ }^{14,36,37}$ no differences between infected and non-infected groups were observed in cholesterol or triglyceride levels, excluding this as a predominant factor.

In humans, the first association between $C$. pneumoniae infection, myocardial infarction and chronic heart disease was shown in patients with anti- $C$. pneumoniae antibodies by Saikku et al. ${ }^{4}$ Later on several other studies have supported this finding suggesting a correlation between $C$. pneumoniae infection and cardiovascular dis- 
ease..$^{8,9,39,40}$ However, the correlation between presence of anti- $C$. pneumoniae antibodies and $C$. pneumoniae antigen in atherosclerotic lesions is questionable. ${ }^{12,15,33,39,41}$ A similar finding is observed in our study as well, since all infected mice were positive for anti-C. pneumoniae antibodies while $C$. pneumoniae antigen was detected in only one third of the aortic arches. This discrepancy may be explained by the notion that immunohistochemical staining has a limited sensitivity detecting $C$. pneumoniae in vascular tissue. A second explanation could be that anti- $C$. pneumoniae antibody in plasma and $C$. pneumoniae antigen in aortic tissue do not necessarily have to be present at the same time. ${ }^{36}$

In summary, this study demonstrates that $C$. pneumoniae infections result in an acceleration of the formation of complex atherosclerotic lesions in Apo E3-Leiden mice either by increasing the influx of activated T-cells to the vascular wall by infected and antigen presenting macrophages or by direct activation of T-cells. 


\section{References}

1. Ross R. Atherosclerosis--an inflammatory disease. N Engl J Med. 1999;340:115-26.

2. Gupta S. Chlamydia pneumoniae, monocyte activation, and azithromycin in coronary heart disease. Am Heart J. 1999;138:S539-41.

3. Danesh J, Collins R, Peto R. Chronic infections and coronary heart disease: is there a link? Lancet. 1997;350:430-6.

4. Saikku P, Leinonen M, Mattila $K$ et al. Serological evidence of an association of a novel Chlamydia, TWAR, with chronic coronary heart disease and acute myocardial infarction. Lancet. 1988;2:983-6.

5. $\quad$ Valtonen VV. Role of infections in atherosclerosis. Am Heart J. 1999;138:S431-3.

6. Mayr M, Kiechl S, Willeit J, Wick G, Xu Q. Infections, immunity, and atherosclerosis: associations of antibodies to Chlamydia pneumoniae, Helicobacter pylori, and cytomegalovirus with immune reactions to heat-shock protein 60 and carotid or femoral atherosclerosis. Circulation. 2000;102:833-9.

7. Radke PW, Merkelbach-Bruse S, Messmer BJ et al. Infectious agents in coronary lesions obtained by endatherectomy: pattern of distribution, coinfection, and clinical findings. Coron Artery Dis. 2001;12:1-6.

8. Gupta S, Leatham EW, Carrington D, Mendall MA, Kaski JC, Camm AJ. Elevated Chlamydia pneumoniae antibodies, cardiovascular events, and azithromycin in male survivors of myocardial infarction. Circulation. 1997;96:404-7.

9. Bachmaier K, Neu N, de la Maza LM, Pal S, Hessel A, Penninger JM. Chlamydia infections and heart disease linked through antigenic mimicry. Science. 1999;283:1335-9.

10. Anderson JL, Muhlestein JB, Carlquist $\mathrm{J}$ et al. Randomized secondary prevention trial of azithromycin in patients with coronary artery disease and serological evidence for Chlamydia pneumoniae infection: The Azithromycin in Coronary Artery Disease: Elimination of Myocardial Infection with Chlamydia (ACADEMIC) study. Circulation. 1999;99:1540-7.

11. Hu H, Pierce GN, Zhong G. The atherogenic effects of chlamydia are dependent on serum cholesterol and specific to Chlamydia pneumoniae. J Clin Invest. 1999;103:747-53.

12. Fong IW, Chiu B, Viira E, Jang D, Mahony JB. De Novo induction of atherosclerosis by Chlamydia pneumoniae in a rabbit model. Infect Immun. 1999;67:6048-55.

13. Moazed TC, Kuo C, Patton DL, Grayston JT, Campbell LA. Experimental rabbit models of Chlamydia pneumoniae infection. Am J Pathol. 1996;148:667-76.

14. Moazed TC, Campbell LA, Rosenfeld ME, Grayston JT, Kuo CC. Chlamydia pneumoniae infection accelerates the progression of atherosclerosis in apolipoprotein E-deficient mice. J Infect Dis. 1999;180:238-41.

15. Muhlestein JB, Anderson JL, Hammond EH et al. Infection with Chlamydia pneumoniae accelerates the development of atherosclerosis and treatment with azithromycin prevents it in a rabbit model. Circulation. 1998;97:633-6.

16. Liu L, Hu H, Ji H, Murdin AD, Pierce GN, Zhong G. Chlamydia pneumoniae infection significantly exacerbates aortic atherosclerosis in an LDLR-/- mouse model within six months. Mol Cell Biochem. 2000;215:123-8.

17. Stary HC, Chandler AB, Dinsmore RE, et al. A definition of advanced types of atherosclerotic lesions and a histological classification of atherosclerosis. A report from the Committee on Vascular Lesions of the Council on Arteriosclerosis, American Heart Association. Arterioscler Thromb Vasc Biol. 1995;15:1512-31. 
18. Lutgens $\mathrm{E}$, Daemen $\mathrm{M}$, Kockx $\mathrm{M}$ et al. Atherosclerosis in APOE*3-Leiden transgenic mice: from proliferative to atheromatous stage. Circulation. 1999;99:276-83.

19. de Boer OJ, van der Wal AC, Becker AE. Atherosclerosis, inflammation, and infection. J Pathol. 2000;190:237-43.

20. Mosorin M, Surcel HM, Laurila A et al. Detection of Chlamydia pneumoniae-reactive T lymphocytes in human atherosclerotic plaques of carotid artery. Arterioscler Thromb Vasc Biol. 2000;20:1061-7.

21. Nadareishvili ZG, Koziol DE, Szekely B et al. Increased CD8(+) T Cells Associated With Chlamydia pneumoniae in Symptomatic Carotid Plaque. Stroke. 2001;32:1966-72.

22. Zhou X, Nicoletti A, Elhage R, Hansson GK. Transfer of CD4(+) T cells aggravates atherosclerosis in immunodeficient apolipoprotein $\mathrm{E}$ knockout mice. Circulation. 2000;102:2919-22.

23. Varadhachary AS, Monestier M, Salgame P. Reciprocal induction of IL-10 and IL-12 from macrophages by low-density lipoprotein and its oxidized forms. Cell Immunol. 2001;213:45-51.

24. Nicoletti A, Paulsson G, Caligiuri G, Zhou X, Hansson GK. Induction of neonatal tolerance to oxidized lipoprotein reduces atherosclerosis in ApoE knockout mice. Mol Med. 2000;6:283-90.

25. Hakkinen T, Karkola K, Yla-Herttuala S. Macrophages, smooth muscle cells, endothelial cells, and T-cells express CD40 and CD40L in fatty streaks and more advanced human atherosclerotic lesions. Colocalization with epitopes of oxidized low-density lipoprotein, scavenger receptor, and CD16 (Fc gammaRIII). Virchows Arch. 2000;437:396-405.

26. Haranaga S, Yamaguchi H, Friedman H, Izumi S-I, Yamamoto Y. Chlamydia pneumoniae infects and multiplies in lymphocytes in vitro. Infection and Immunity. 2001;69:7753-7759.

27. van Vlijmen BJ, van den Maagdenberg AM, Gijbels MJ et al. Diet-induced hyperlipoproteinemia and atherosclerosis in apolipoprotein E3-Leiden transgenic mice. J Clin Invest. 1994;93:1403-10.

28. Roblin PM, Dumornay W, Hammerschlag MR. Use of HEp-2 cells for improved isolation and passage of Chlamydia pneumoniae. J Clin Microbiol. 1992;30:1968-71.

29. Rothstein NM, Quinn TC, Madico G, Gaydos CA, Lowenstein CJ. Effect of azithromycin on murine arteriosclerosis exacerbated by Chlamydia pneumoniae. J Infect Dis. 2001;183:232-238.

30. Moazed TC, Kuo C, Grayston JT, Campbell LA. Murine models of Chlamydia pneumoniae infection and atherosclerosis. J Infect Dis. 1997;175:883-90.

31. Moazed TC, Kuo CC, Grayston JT, Campbell LA. Evidence of systemic dissemination of Chlamydia pneumoniae via macrophages in the mouse. J Infect Dis. 1998;177:1322-5.

32. Nakashima Y, Plump AS, Raines EW, Breslow JL, Ross R. ApoE-deficient mice develop lesions of all phases of atherosclerosis throughout the arterial tree. Arterioscler Thromb. 1994;14:133-40.

33. Blessing E, Lin TM, Campbell LA, Rosenfeld ME, Lloyd D, Kuo C. Chlamydia pneumoniae induces inflammatory changes in the heart and aorta of normocholesterolemic C57BL/6J mice. Infect Immun. 2000;68:4765-8.

34. Hansson G. Immune mechanisms in atherorosclerosis. Arterioscler Thromb Vasc Biol. 2001;21:1897-90.

35. Kaul R, Uphoff J, Wiedeman J, Yadlapalli S, Wenman WM. Detection of Chlamydia pneumoniae DNA in CD3+ lymphocytes from healthy blood donors and patients with coronary artery disease. Circulation. 2000;102:2341-6. 
36. Aalto-Setala K, Laitinen K, Erkkila L et al. Chlamydia pneumoniae does not increase atherosclerosis in the aortic root of apolipoprotein E-deficient mice. Arterioscler Thromb Vasc Biol. 2001;21:578-84.

37. Caligiuri G, Rottenberg M, Nicoletti A, Wigzell H, Hansson GK. Chlamydia pneumoniae infection does not induce or modify atherosclerosis in mice. Circulation. 2001;103:2834-8.

38. Paigen B, Ishida BY, Verstuyft J, Winters RB, Albee D. Atherosclerosis susceptibility differences among progenitors of recombinant inbred strains of mice. Arteriosclerosis. 1990;10:316-23.

39. Campbell LA, O'Brien ER, Cappuccio AL et al. Detection of Chlamydia pneumoniae TWAR in human coronary atherectomy tissues. J Infect Dis. 1995;172:585-8.

40. Danesh J, Whincup $P$, Walker $M$ et al. Chlamydia pneumoniae IgG titres and coronary heart disease: prospective study and meta-analysis. Bmj. 2000;321:208-13.

41. Ramirez JA. Isolation of Chlamydia pneumoniae from the coronary artery of a patient with coronary atherosclerosis. The Chlamydia pneumoniae/Atherosclerosis Study Group. Ann Intern Med. 1996;125:979-82. 


\section{CHAPTER 4}

\section{Chlamydia pneumoniae infections augment atherosclerotic lesion formation: a role for serum amyloid $P$}

R Ezzahiri ${ }^{1}$, FRM Stassen², HRM Kurvers ${ }^{1}$, V Dolmans²,

PJEHM Kitslaar ${ }^{1}$, CA Bruggeman ${ }^{2}$.

Department of Surgery ${ }^{1}$ and Medical Microbiology, ${ }^{2}$

University Hospital Maastricht, The Netherlands

Acta Pathalogica microbiologica Scandinavica, 2006 Feb;114(2):127-30. 


\begin{abstract}
Objectives: Multiple reports have demonstrated an association between Chlamydia pneumoniae (Cpn) and cardiovascular disease. In this study, we evaluated the effect of $\mathrm{Cpn}$ infections on early lesion progression in C57BL/6J mice. Since plaque formation in these mice does not develop past the initial stage, we thought these mice may be a better model for unravelling the effect of Cpn infection on early lesion type progression.

Methods: C57BL/6J mice were fed an atherogenic diet and injected 10 times with 5 107 IFU Cpn or mock. At sacrifice, lesion number, size and type were analysed. To study the role of Cpn on inflammation, serum amyloid P (SAP) in plasma was determined as well as T-cells, macrophages and SAP in the lesions.

Results: In the aortic sinus of both groups type 2 lesions were found. Cpn infection resulted in a 2.2-fold increase in total lesion size (Cpn: $10821 \pm 2429 \mathrm{~mm}^{2}$ vs. mock: $\left.5022 \pm 1348 \mathrm{~mm}^{2} ; \mathrm{p}=0.04\right)$. No difference in lesion number was observed. Also, Cpn infection increased SAP in the lesions from $1.10^{-4} \pm 0.1 .10^{-4}$ SAP positive cells/lesion area to $10.10^{-4} \pm 1.10^{-4}$ SAP positive cells/lesion area $(p=0.05)$. The influx of T-lymphocytes and macrophages in the lesions as well as SAP plasma levels were not different between groups.

Conclusion: Multiple Cpn infections resulted in a significant increase in total lesion size of $\mathrm{C} 57 \mathrm{BL} / 6 \mathrm{~J}$ mice. Increase in total SAP positive area in infected mice suggests a role for this acute phase protein in lesion enlargement.
\end{abstract}




\section{Introduction}

Chlamydia pneumoniae (Cpn) infections are probably involved in human atherosclerosis. Since the original observation by Saikku and coworkers, ${ }^{1}$ over 30 epidemiological studies have confirmed the association between $\mathrm{Cpn}$ infection and atherosclerosis. ${ }^{2}$ The majority of these studies is based on serology or the presence of Cpn DNA or antigens in the vascular wall. While many in vitro studies have likewise demonstrated that $\mathrm{Cpn}$ is able to infect various components of the atherosclerotic vascular wall and results in production of multiple pro-inflammatory and pro-atherogenic cytokines and chemokines, the exact mechanisms by which Cpn contributes to plaque formation in vivo remains to be established. To unravel these mechanisms, genetically modified mice have been used. In low density lipoprotein-receptor knockout (LDLr-/-) mice, Cpn infection has been shown to result in an enlargement of the total atherosclerotic plaque area in the aortic sinus. ${ }^{3}$ Along the same line, it has been demonstrated that Cpn infection accelerates the atherosclerotic process in ApoE -/- mice..$^{4-6}$ Furthermore, we recently demonstrated that $\mathrm{Cpn}$ infection accelerates the formation of advanced atherosclerotic lesions in ApoE3-Leiden mice, ${ }^{7}$ although the observed changes were subtle. In this study we evaluated the formation of atherosclerotic plaques in $\mathrm{C} 57 \mathrm{BL} / 6 \mathrm{~J}$ mice following a prolonged period of high fat/high cholesterol diet with multiple $\mathrm{Cpn}$ infections. C57BL/6J mice, which are the parental background strain for most atherosclerotic mouse models, only develop initial lesions when fed an atherogenic diet. $^{8-10}$ We hypothesised that concomitant Cpn infections result in the progression of early lesions into advanced lesion types.

Since the late 90's atherosclerosis has been described as an inflammatory disease. ${ }^{11}$ Pathological and intervention studies have implicated organisms like Cpn in initiating or maintaining inflammation. ${ }^{2,12,13}$ Also, increased levels of acute phase proteins as C-reactive protein (CRP) ${ }^{14}$ and, in the mouse, serum amyloid $P(S A P)^{15}$ have been linked to progression of atherosclerotic vascular disease. SAP has been demonstrated in amyloid deposits of tangles and plaques in Alzheimer's disease patients, ${ }^{16}$ but also in atherosclerotic intima of human abdominal aortas..$^{15}$ In this study, the role of $\mathrm{Cpn}$ infection on inflammation was studied through assessment of SAP in plasma and in atherosclerotic lesions of the aortic sinus of C57BL/6J mice. In addition, we compared the presence of inflammatory cells in atherosclerotic lesions, total lesion area and lesion number in mice, which were fed an atherogenic diet for 10 months with or without 10 monthly inoculations of $\mathrm{Cpn}$.

\section{Material and Methods}

\section{Mice}

Twenty male specific pathogen free C57BL/6J mice were bred and housed under standard conditions at the Central Animal Facility at the Maastricht University. During the study mice were fed a high fat/high cholesterol diet containing $15 \%$ cacao butter, $0.5 \%$ 
cholate, $1 \%$ cholesterol, $40.5 \%$ sucrose, $10 \%$ cornstarch, $1 \%$ corn oil and $4.7 \%$ cellulose (Hope farms BV, Woerden, The Netherlands) and water ad libitum. This animal experiment was approved by the institutional committee for the welfare of laboratory animals of the Maastricht University.

\section{C. pneumoniae}

Cpn strain TWAR 2043 (ATCC VR-1355) was cultured in Hep-2 cells as previously published. ${ }^{17}$ Bacterial titres were determined by titration in Hep-2 cells and stained with fluorescein-isothiocyanate-conjugated (FITC) monoclonal antibody RR 402 (Dako, Glostrup, Denmark) directed against elementary bodies of $\mathrm{Cpn}$.

\section{Experimental design}

At the age of seventeen weeks the high fat/high cholesterol diet was started and half of the mice were injected intraperitoneally with 5x107 IFU Cpn, dissolved in 200 I of sterile phosphate-buffered saline (PBS). In humans, multiple Cpn infections occur throughout one's lifetime. Therefore, mice received 9 consecutive monthly inoculations after the first injection (Cpn). Control mice (Mock) were injected with PBS only.

\section{Tissue handling}

At sacrifice, 25 days after the last inoculation, mice were anaesthetized with a weightadjusted dose of pentobarbital (Nembutal ${ }^{\circledR}$, Sanofi BV, Maassluis, The Netherlands) and blood was collected from the left ventricular apex of the heart for analysis of $\mathrm{Cpn}$ antibodies and serum amyloid P (SAP). The arterial tree was perfused with PBS through a catheter placed in the left ventricular apex. The aortic sinus was removed, fixed overnight in 3.7\% PBS buffered formaldehyde and embedded in paraffin. Serial longitudinal $4 \mathrm{~mm}$ sections of the aortic sinus were cut, stained and analyzed. Thoracic and abdominal aorta as well as spleen and liver were dissected and stored at $-70 \mathrm{C}$ for Cpn DNA analysis.

\section{Atherosclerotic lesion analysis}

Since atherosclerotic lesion development initiates in the aortic sinus, $4 \mathrm{~mm}$ sections of the aortic root were used from the level where valves were visible until the valves had disappeared. The middle section was used for an Elastica van Gieson (EvG) staining for analysis of atherosclerotic lesion type, size and number. This middle section was used as a "reference section" to select surrounding sections, $4 \mathrm{~mm}$ apart, for analysis of T-lymphocytes and macrophages. Atherosclerotic lesion type was determined according to the guidelines of the American Heart Association. $7,18,19$ For area analysis a microscope coupled to a computer-assisted morphometry system (Analysis Soft Imaging System, GmbH, Münster, Germany) was used.

Analysis of T-lymphocytes and macrophages in the atherosclerotic lesions In order to detect T-lymphocytes in the atherosclerotic lesions, a rabbit-anti-CD3+ polyclonal antibody was used (Dako, Glostrup, Denmark). After a blocking step with 
Bovine Serum Albumin(BSA)/PBS 2\% for aspecific binding, slides were incubated with the $\mathrm{CD}^{+}$polyclonal antibody for 60 minutes at a dilution of 1:200, followed by a second-step incubation with a biotinylated swine-anti-rabbit $\lg G$ at a dilution of 1:1000 (Dako, Glostrup, Denmark) for 30 minutes. Sections were then labelled with an alkaline phosphatase coupled ABC reagent (Dako, Glostrup, Denmark) for 30 minutes. Alkaline phosphatase activity was visualized using Fast-red (Sigma Chemical Co, St. Louis, United States). Rabbit-anti-rat IgG (Dako, Glostrup, Denmark) was used as a negative control. For positive controls, tissue sections from mice spleens were used. T-lymphocytes in the atherosclerotic lesion were counted and expressed as the ratio between the number of T-lymphocytes and total plaque area.

Macrophages were detected in the lesion using a rat anti-mouse Mac-3 monoclonal antibody (Pharmingen, Heidelberg, Germany). ${ }^{20}$ After a heating step with a mixture of AgR buffer (Dako, Glostrup, Denmark), citric acid (Merck, Darmstadt, Germany) and sodium citrate (Merck, Darmstadt, Germany) for 10 minutes, blocking steps were performed for aspecific binding. Slides were incubated with a mixture of methanol and $\mathrm{H} 2 \mathrm{O} 2$ for 15 minutes followed by rabbit serum for 30 minutes. Then the slides were incubated with the Mac-3 monoclonal antibody at a 1:30 dilution for 24 hours, followed by a second step with biotinylated rabbit-anti-rat IgG (Dako, Glostrup, Denmark) at a dilution of 1:300 for 30 minutes. Finally, sections were labelled with an alkaline phosphatase coupled ABC reagent (Dako, Glostrup, Denmark) for 30 minutes. Alkaline phosphatase activity was visualized using Alkaline Phosphatase Substrate Kit I (Vector Laboratories, Burlingame, USA). For positive controls, tissue sections of mice spleens were used. The presence of macrophages was expressed as the ratio between the area positive for Mac-3 and total plaque area using a microscope coupled to a computer-assisted morphometry system (Analysis Soft Imaging System, $\mathrm{GmbH}$, Münster, Germany).

\section{Detection of SAP in serum and atherosclerotic lesions}

SAP levels in the serum of $\mathrm{Cpn}$ infected and mock injected mice were measured using the enzyme linked immunosorbent assay (ELISA) technique previously used by Daemen at al. ${ }^{21}$

For detection of SAP in atherosclerotic lesions of the aortic sinus, a rabbit-anti-SAP polyclonal antibody was used(Calbiochem San Diego, United States). After blocking steps for peroxidase using 3\% $\mathrm{H} 2 \mathrm{O} 2$ and $\mathrm{BSA} / \mathrm{PBS} 2 \%$ for aspecific binding, slides were incubated with rabbit-anti-SAP (Calbiochem, San Diego, United States) for 60 minutes at a dilution of 1:250, followed by a second-step incubation with a biotinylated swine-anti-rabbit lgG at a dilution of 1:1000 (Dako, Glostrup, Denmark) for 30 minutes. Finally, sections were labelled with an alkaline phosphatase coupled ABC reagent (Dako, Glostrup, Denmark) for 30 minutes. Alkaline phosphatase activity was visualised using Fast-red (Sigma Chemical Co, St. Louis, United States) For positive controls, tissue sections of murine brains with Alzheimer disease and liver sections were used. Rabbit-anti-rat IgG (Dako, Glostrup, Denmark) was used as a negative control. The presence of SAP was expressed as the ratio between the area positive 
for SAP and total plaque area using a microscope coupled to a computer-assisted morphometry system.

\section{Detection of Cpn antibodies and Cpn DNA}

Cpn antibodies were measured with the indirect micro-immunofluorescence (MIF) technique using mouse plasma sample dilutions 1:10 and 1:100 on antigen-coated slides (Labsystems, Helsinki, Finland). Goat-anti-mouse IgG conjugated to FITC (Dako, Glostrup, Denmark) was used as the secondary antibody. The slides were analysed by 2 independent observers.

To detect the presence of Cpn DNA in the organs, a sensitive in house developed polymerase chain reaction (PCR) was used (detection ability of 1 copy of DNA). The following sequences were used as primers: sense 5'-TTA TTA ATT GAT GGT ACA ATA-3'; antisense 5'-ATC TAC GGC AGT AGT ATA GTT-3', accession number AF131889.22

PCR was performed in a total volume of $50 \mathrm{ml}$, containing $1 \mathrm{mg}$ DNA. DNA was extracted from vascular tissue with the Wizard Genomic DNA purification kit (Promega, Germany). Amplification was done by thermal cycling starting at $37^{\circ} \mathrm{C}$ for ten minutes and $95^{\circ} \mathrm{C}$ for fifteen minutes. Then 20 cycles of "Touchdown PCR" were performed from $60^{\circ} \mathrm{C}$ to $50^{\circ} \mathrm{C}$, followed by 40 cycles of 1 minute at $94^{\circ} \mathrm{C}, 50^{\circ} \mathrm{C}$, and $72^{\circ} \mathrm{C}$.

The PCR products were resolved in a $2 \%$ agarose gel, stained with ethidium bromide, and photographed.

\section{Lipid profiles}

Total plasma cholesterol and triglyceride concentrations were measured with a standard cholesterol oxidase method performed on Beckman Synchron CX Systems. ${ }^{23}$

\section{Statistical analysis}

Differences in lipid profile, atherosclerotic lesion size and type, influx of T-lymphocytes and macrophages and SAP levels in serum and plaque between the Cpn and mock group were compared with the Mann-Whitney test. Only mice with clear signs of atherosclerosis in the aortic sinus were included for analysis. A P-value of $<0.05$ was considered statistically significant. All data are presented as mean \pm SEM.

\section{Results}

To investigate the effect of Cpn infection on early lesion type progression, 20 male C57BL/6J mice were used. Mice in the present study showed no clinical signs following Cpn inoculations. No mortality was observed. This is in line with results of Blessing et al., ${ }^{24}$ that did not observe mortality in C57BL/6J mice inoculated with Cpn. 
Detection of Cpn DNA and anti-Cpn antibodies

In all Cpn-infected mice antibodies against Cpn were detected in plasma, indicating that all mice were successfully infected. No Cpn antibodies were detected in the plasma of the mock-infected group. Furthermore, Cpn specific DNA was detected in 5/10 vascular tissue specimens of Cpn-infected group by PCR, which is comparable with earlier published Cpn PCR results in aortic tissue of mice. ${ }^{25}$ In aortic tissue samples of mock-injected mice, no Cpn DNA was detected.

\section{Lipid profiles}

Blood was collected from the Cpn-infected and the mock-infected mice for analysis of total plasma cholesterol and triglyceride concentrations. Data are presented in table 1. No difference was observed in cholesterol and triglyceride plasma levels between the Cpn-infected and mock-infected group, suggesting that Cpn infection has no effect on plasma lipid levels.

Table 1. Lipid profiles, lesion number/aortic arch and number inflammatory cells/lesion area in mock injected or Cpn infected C57BL/6J mice, n: number of mice analysed.

\begin{tabular}{ccccc}
\hline & $\mathrm{n}$ & Mock-infected & Cpn-infected & $\mathrm{p}$ \\
\hline $\begin{array}{c}\text { Lipid profile (mmol/L) } \\
\text { Cholesterol }\end{array}$ & $10 / 10$ & $7.4 \pm 0.4$ & $8.0 \pm 0.2$ & $\mathrm{p}=0.11$ \\
Triglycerides & $10 / 10$ & $0.051 \pm 0.022$ & $0.069 \pm 0.017$ & $\mathrm{p}=0.49$ \\
Lesion number/aortic sinus & $9 / 9$ & $1.67 \pm 0.35$ & $2.33 \pm 0.53$ & $\mathrm{p}=0.16$ \\
Inflammatory cells/lesion area & & & & \\
T-cells (x 10-4) & $8 / 8$ & $2.96 \pm 1.69$ & $1.30 \pm 0.66$ & $\mathrm{p}=0.23$ \\
Macrophages & $5 / 7$ & $0.11 \pm 0.04$ & $0.17 \pm 0.05$ & $\mathrm{p}=0.17$ \\
\hline
\end{tabular}

Evaluation of atherosclerotic lesions

In the Cpn-infected as well as in the mock-infected group all atherosclerotic lesions found could be classified as type 2 lesions ("fatty streaks") according to the histological classification of AHA. The numbers of atherosclerotic lesions are presented in table 1. No significant difference in lesion number was observed between groups.

When atherosclerotic lesion area in the aortic sinus was measured a statistically significant increase was observed in Cpn infected C57BL/6J mice compared to mockinfected mice (Mock: $5022 \pm 1348 \mu \mathrm{m} 2$ vs. Cpn: $10821 \pm 2429 \mu \mathrm{m} 2, \mathrm{p}=0.04$, figure 1 ). 
Figure 1. Quantitative comparisons of mean aortic lesion areas between Cpn infected and mock injected 14 months old C56BL/6J mice, fed a high fat/high cholesterol diet for 10 months. Data are presented as mean \pm SEM.

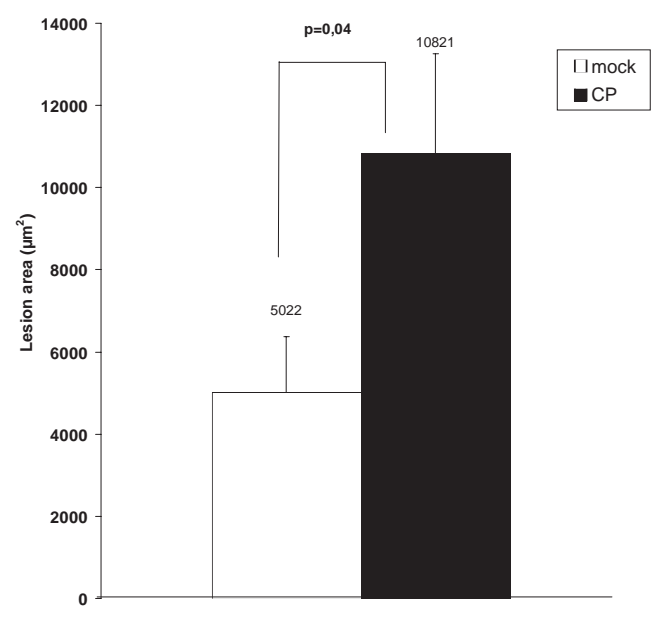

Figure 2. Results of SAP staining in atherosclerotic lesions of Cpn infected and mock injected C56BL/6J mice. Data are expressed as the number of SAP positive cells divided by total plaque area and presented as mean \pm SEM.

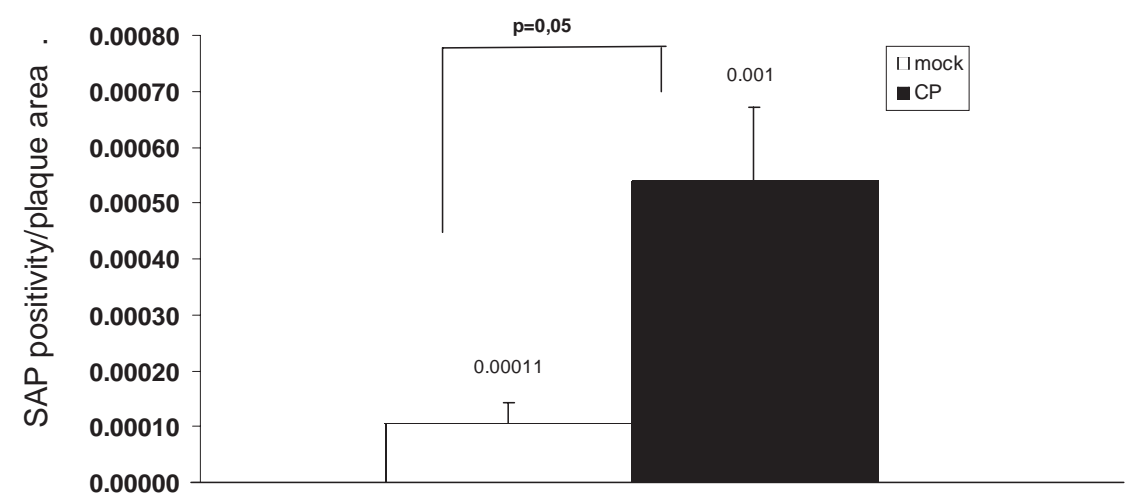

Inflammatory cells in the atherosclerotic lesions

The effect of Cpn infection on influx of T-lymphocytes and macrophages was determined in the atherosclerotic lesions of the aortic sinus by immunohistochemical staining. Data are presented in table 1. There was no difference in T-cell or macrophage influx between Cpn-infected and mock-injected mice. 
Figure 3. SAP staining showing SAP antigen in the subendothelial layer of the lesion of Cpn-infected mouse. Magnification 200x and 400x.
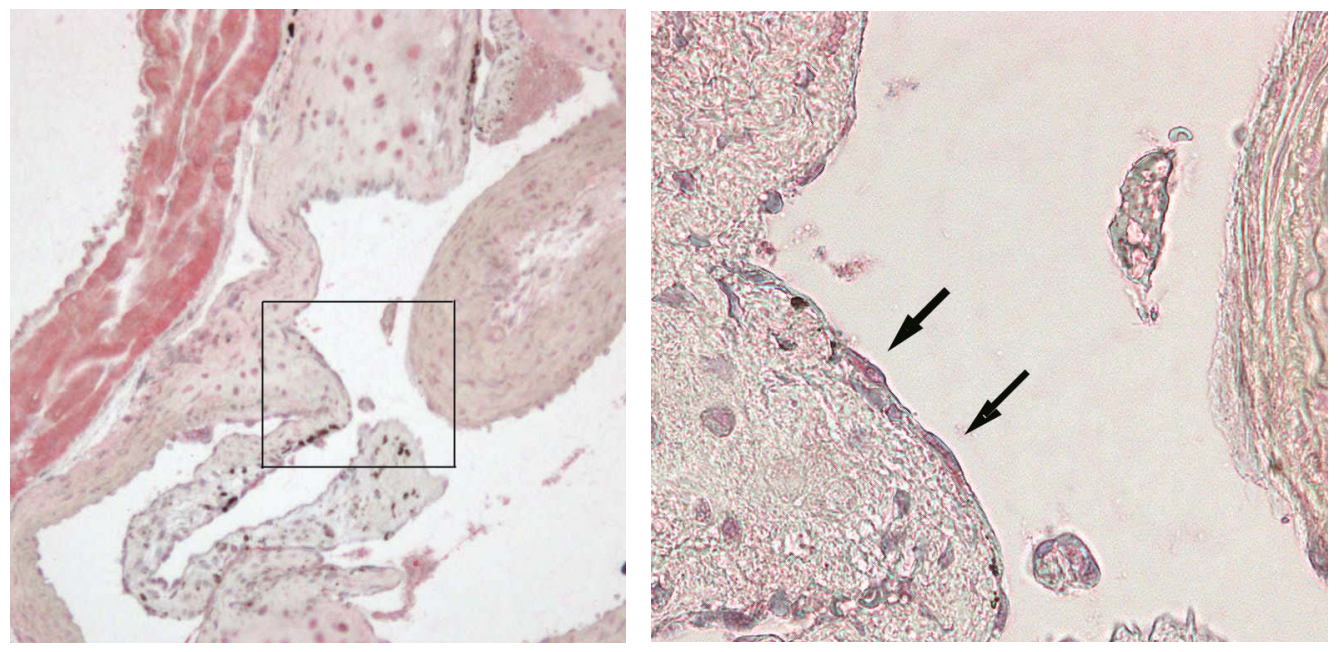

SAP in atherosclerotic lesions and serum

When SAP in the atherosclerotic lesions was determined, a 10 fold increase was observed in SAP positive area in the lesions of the aortic sinus from $1.10^{-4} \pm 0.1 .10^{-4}$ SAP positive cells per lesion area in control mice to $10.10^{-4} \pm 1.10^{-4}$ SAP positive cells per lesion area in Cpn-infected mice ( $p=0.05$, figure 2). SAP staining was mainly observed in the subendothelial layer of the plaque (figure 3 ).

The effect of Cpn infection on serum SAP levels was measured by the ELISA technique which demonstrated similar levels in SAP $(13.69 \mathrm{mg} / \mathrm{ml}$ vs. $14.15 \mathrm{mg} / \mathrm{ml}, \mathrm{p}=0.4$ ) in Cpn and control group, respectively.

These data suggest that $\mathrm{Cpn}$ infection affects atherosclerotic lesion size through increasing SAP antigen in these lesions without changing SAP levels systemically.

\section{Discussion}

Many research groups have focused on the influence of $\mathrm{Cpn}$ infection in cardiovascular diseases ${ }^{26}$ In terms of atherosclerosis, the presence of $\mathrm{Cpn}$ in atherosclerotic lesions has been demonstrated by PCR, immunohistochemistry and electronmicroscopy. ${ }^{27-30}$ On a few occasions, $\mathrm{Cpn}$ has been cultured from lesions. ${ }^{31-33}$ Furthermore, numerous in vitro studies have demonstrated that Cpn infection induces pro-atherogenic changes in various cellular components of the atherosclerotic vessel wall, such as foam cell formation, ${ }^{34}$ endothelial expression of adhesion molecules and chemokines, ${ }^{35}$ stimulation of transendothelial leukocyte migration, ${ }^{36}$ smooth muscle cell proliferation, ${ }^{37}$ endothelial production of tissue factor ${ }^{38}$ and plasminogen activator 
inhibitor $1^{39}$ and macrophage production of matrix metalloproteinase $9 .{ }^{40}$ All these findings suggest that Cpn may play a causal role in the development of atherosclerosis.

The effect of Cpn on atherogenesis has been studied in mice models. For these studies mostly genetically modified mice such as ApoE and LDLr knockout mice have been used. These mice develop atherosclerotic lesions in their vascular tree when fed a high fat/high cholesterol diet. ${ }^{41}$ Concomitant Cpn infection has been shown to stimulate plaque formation in these mice. ${ }^{4-6}$ Furthermore, we recently demonstrated that Cpn infection accelerates the formation of more advanced atherosclerotic lesions in ApoE3-Leiden mice. ${ }^{7}$ In C57BL/6J mice, the parental, normocholesterolemic background strain of the genetically modified mice (including the ApoE3-Leiden), plaque formation in the aortic sinus does not develop past the initial stage even after extended periods of a high fat/high cholesterol diet. ${ }^{8}$ As C57BL/6J mice on a high fat/high cholesterol diet may thus be a better model for unravelling the effect of Cpn infection on early lesion type progression, we hypothesized that Cpn infections induce more complicated lesion types in the aortic sinus of these mice. For this purpose, mice were fed a high fat/high cholesterol diet starting at the age of 17 weeks and sacrificed at approximately 14 months of age. As expected, only type 2 lesions were found in the aortic sinus of these uninfected control mice. The aortic sinus of mice which additionally received ten monthly inoculations with 5x107 IFU Cpn also demonstrated no advanced lesion formation suggesting that Cpn infections do not lead to the formation of more complicated lesions. This finding is in contrast with our previous finding in ApoE3-Leiden mice, ${ }^{7}$ where Cpn infections accelerated formation of complex (advanced) atherosclerotic lesions without increasing lesion size. Some differences between high fat/high cholesterol fed C57BL/6J and ApoE3-Leiden mice may account for this discrepancy. Although our C57BL/6J mice show moderately elevated levels of serum cholesterol and triglycerides, levels are markedly higher in ApoE3-Leiden following prolonged periods of high fat/high cholesterol. ${ }^{42}$ As hypercholesterolemia may be a prerequisite for an effect of Cpn on plaque progression, ${ }^{3}$ this may explain the lack of effect of Cpn infection on plaque progression in C57BL/6J mice. Furthermore, genetic modulation of various components of the lipid metabolism pathway has been shown to alter the susceptibility of mice to various infections. ApoE-/- mice display an increased susceptibility to Klebsiella pneumoniae ${ }^{43}$ or Listeria monocytogenes. ${ }^{44}$ LDLr-/- mice, on the other hand, are protected from infections with Klebsiella pneumoniae ${ }^{45}$ but show an increased mortality following systemic candidiasis. ${ }^{46}$ Until now it has not been established whether the lack of ApoE or hypercholesterolemia affect the susceptibility of mice to Cpn infection. As Cpn belongs to the large family of Gram-negative bacteria, as Klebsiella pneumoniae also does, an increased susceptibility to Cpn infection may be anticipated in ApoE3-Leiden mice, which may eventually explain the observed differences in advanced lesion formation. Future studies using high sensitive techniques such as Cpn real time (RT-)PCR will be needed to elucidate this aspect.

Apart from lesion type, we also measured total lesion area in both groups and found a marked increase in total lesion area in the aortic root of Cpn infected mice. Blessing 
and colleagues observed a similar increase in total lesion area in the aortic root of $\mathrm{Cpn}$ infected, high fat/high cholesterol fed C57BL/6J mice. ${ }^{9}$ In contrast to our study, they infected their mice less frequently than we did ( 3 vs. 10 times) and sacrificed them at a much younger age (7 months vs. 14 months). Despite these differences, total lesion sizes did not differ between their and our study.

Recently, we demonstrated that there is a significant increase in the number of Tcells, present in the aortic arch of ApoE3-Leiden mice early (1 month) after the first injection. ${ }^{7}$ We hypothesized that this increase in T cell influx may contribute to the observed acceleration of advanced plaque formation at later time points, i.e. 6 and 9 months p.i. However, at these later time points no differences are observed in T-cell number or inflammatory cells per lesion area. Nonetheless, in the present study $\mathrm{T}$ cell number at 1 month post infection was not evaluated.

Increasing evidence suggests a role for acute phase proteins in cardiovascular disorders. Elevated C-reactive protein (CRP) levels have been shown to be a strong independent risk factor for future cardiovascular complications in patients. ${ }^{14,47-50}$ In addition, multiple pro-atherogenic effects, such as the upregulation of adhesion molecule expression by endothelial cells and production of tissue factor, ${ }^{51} \mathrm{TNF} \alpha$ and II-1(52) by macrophages following exposure to CRP, have been demonstrated in vitro.

And although generally accepted that CRP is mainly produced by hepatocytes, we and other recently demonstrated the presence and production of CRP in the vascular wall. ${ }^{53,54}$ Also SAP, the other member of the pentraxin family, has been suggested to contribute to atherosclerosis. $\mathrm{Li}$ et al. demonstrated the presence of SAP in human atherosclerotic lesions and suggested that the proatherogenic effects may be related to its interactions with various lipoproteins..$^{15}$ In mice, SAP is the most important acute phase protein and SAP plasma levels are rapidly increased following LPS exposure as well as infection. Therefore, we investigated whether SAP is increased in our Cpninfected mice. As Cpn could be demonstrated in vascular tissue, it may be speculated that this results in the formation of such cellular debris thereby explaining the presence of SAP at these sites. SAP has been shown to play a role in the binding and clearance of host- and pathogen-derived cellular debris at sites of acute inflammation as part of the innate immune response. Whether SAP enters the subendothelium from the circulation or is produced locally, as recently demonstrated for CRP, ${ }^{53,54}$ remains to be established. Also, the mechanisms by which SAP may promote plaque formation are unclear until now. Following binding to host- and pathogen-derived cellular debris, SAP may activate the complement cascade which may represent an important initiating event in early atherogenesis..$^{55,56}$ In addition, pentraxins have been shown to bind to macrophages and to enhance the uptake and degradation of LDL via the macrophages scavenger receptor. ${ }^{57,58}$ Intriguingly, Gates and Reese ${ }^{59}$ demonstrated that activation of sphingomyelinase, an enzyme associated with the pathogenesis of atherosclerosis, requires the presence of SAP. This is supported by findings from Wong and colleagues, ${ }^{59}$ who demonstrated that acute systemic inflammation up-regulates sphingomyelinase in vivo. This activated sphingomyelinase may then convert lipoproteins into potent inducers of macrophage foam cell formation in hypercholes- 
terolemic mice, ${ }^{60}$ which may results in increased formation of early lesions. In summary, various lines of evidence suggest a role for SAP in atherogenesis, in particular following infection, but further research is awaited to elucidate the exact mechanisms underlying its effects on lesion formation. In contrast to increased SAP in plaques, no differences in circulating SAP levels were observed between infected and uninfected mice. It may be speculated that the late time point after infection ( 25 days after the last inoculation) at which SAP levels were determined could explain the similar plasma SAP levels.

In summary, our results demonstrate that multiple infections with Cpn result in a marked enlargement of the atherosclerotic lesions in the aortic sinus of C57BL/6J mice. This was accompanied by an enhanced SAP immunoreactivity in lesions of Cpninfected mice thereby suggesting a potential role for this acute phase protein in Cpn mediated aggravation of atherosclerosis. This finding provides further evidence for a role of $\mathrm{Cpn}$ in atherogenesis. 


\section{References}

1. Saikku P, Leinonen M, Mattila K, Ekman MR, Nieminen MS, Makela PH, et al. Serological evidence of an association of a novel Chlamydia, TWAR, with chronic coronary heart disease and acute myocardial infarction. Lancet 1988;2(8618):983-6.

2. Leinonen M, Saikku P. Infections and atherosclerosis. Scand Cardiovasc J 2000;34(1):12-20.

3. Hu H, Pierce GN, Zhong G. The atherogenic effects of chlamydia are dependent on serum cholesterol and specific to Chlamydia pneumoniae. J Clin Invest 1999;103(5):747-53.

4. Moazed TC, Campbell LA, Rosenfeld ME, Grayston JT, Kuo CC. Chlamydia pneumoniae infection accelerates the progression of atherosclerosis in apolipoprotein E-deficient mice. J Infect Dis 1999;180(1):238-41.

5. Rothstein NM, Quinn TC, Madico G, Gaydos CA, Lowenstein CJ. Effect of azithromycin on murine arteriosclerosis exacerbated by Chlamydia pneumoniae. J Infect Dis 2001;183(2):232-238.

6. Burnett MS, Gaydos CA, Madico GE, Glad SM, Paigen B, Quinn TC, et al. Atherosclerosis in apoE knockout mice infected with multiple pathogens. J Infect Dis 2001;183(2):226-231.

7. Ezzahiri R, Nelissen-Vrancken H, Kurvers H, Stassen F, Vliegen I, Grauls G, et al. Chlamydophila pneumoniae (Chlamydia pneumoniae) accelerates formation of complex atherosclerotic lesion in Apo E3-Leiden mice. Cardiovascular Research 2002;56(2):269-76.

8. Paigen B, Ishida BY, Verstuyft J, Winters RB, Albee D. Atherosclerosis susceptibility differences among progenitors of recombinant inbred strains of mice. Arteriosclerosis 1990;10(2):316-23.

9. Blessing E, Campbell LA, Rosenfeld ME, Chough N, Kuo CC. Chlamydia pneumoniae infection accelerates hyperlipidemia induced atherosclerotic lesion development in C57BL/6J mice. Atherosclerosis 2001;158(1):13-7.

10. Chesebro BB, Blessing E, Kuo CC, Rosenfeld ME, Puolakkainen M, Campbell LA. Nitric oxide synthase plays a role in Chlamydia pneumoniae-induced atherosclerosis. Cardiovasc Res 2003;60(1):170-4.

11. Ross R. The pathogenesis of atherosclerosis: a perspective for the 1990s. Nature 1993;362(6423):801-9.

12. Gupta S, Leatham EW, Carrington D, Mendall MA, Kaski JC, Camm AJ. Elevated Chlamydia pneumoniae antibodies, cardiovascular events, and azithromycin in male survivors of myocardial infarction. Circulation 1997;96(2):404-7.

13. Campbell LA, O'Brien ER, Cappuccio AL, Kuo CC, Wang SP, Stewart D, et al. Detection of Chlamydia pneumoniae TWAR in human coronary atherectomy tissues. J Infect Dis 1995;172(2):585-8.

14. Ridker PM, Cushman M, Stampfer MJ, Tracy RP, Hennekens $\mathrm{CH}$. Inflammation, aspirin, and the risk of cardiovascular disease in apparently healthy men. $\mathrm{N}$ Engl $\mathrm{J}$ Med 1997;336(14):973-9.

15. Li XA, Hatanaka K, Ishibashi-Ueda H, Yutani C, Yamamoto A. Characterization of serum amyloid $\mathrm{P}$ component from human aortic atherosclerotic lesions. Arterioscler Thromb Vasc Biol 1995;15(2):252-7.

16. Kalaria RN, Grahovac I. Serum amyloid P immunoreactivity in hippocampal tangles, plaques and vessels: implications for leakage across the blood-brain barrier in Alzheimer's disease. Brain Res 1990;516(2):349-53.

17. Roblin PM, Dumornay W, Hammerschlag MR. Use of HEp-2 cells for improved isolation and passage of Chlamydia pneumoniae. J Clin Microbiol 1992;30(8):1968-71. 
18. Stary HC, Chandler AB, Dinsmore RE, Fuster V, Glagov S, Insull W, Jr., et al. A definition of advanced types of atherosclerotic lesions and a histological classification of atherosclerosis. A report from the Committee on Vascular Lesions of the Council on Arteriosclerosis, American Heart Association. Arterioscler Thromb Vasc Biol 1995;15(9):1512-31.

19. Vliegen I, Stassen F, Grauls G, Blok R, Bruggeman C. MCMV infection increases early Tlymphocyte influx in atherosclerotic lesions in apoE knockout mice. J Clin Virol 2002;25 Suppl 2:S159-71.

20. Flotte TJ, Springer TA, Thorbecke GJ. Dendritic cell and macrophage staining by monoclonal antibodies in tissue sections and epidermal sheets. Am J Pathol 1983;111(1):112-24.

21. Daemen MA, Heemskerk VH, van't Veer C, Denecker G, Wolfs TG, Vandenabeele P, et al. Functional protection by acute phase proteins alpha(1)-acid glycoprotein and alpha(1)antitrypsin against ischemia/reperfusion injury by preventing apoptosis and inflammation. Circulation 2000;102(12):1420-6.

22. Tong CY, Sillis M. Detection of Chlamydia pneumoniae and Chlamydia psittaci in sputum samples by PCR. J Clin Pathol 1993;46(4):313-7.

23. Fong IW, Chiu B, Viira E, Jang D, Mahony JB. De Novo induction of atherosclerosis by Chlamydia pneumoniae in a rabbit model. Infect Immun 1999;67(11):6048-55.

24. Blessing E, Lin TM, Campbell LA, Rosenfeld ME, Lloyd D, Kuo C. Chlamydia pneumoniae induces inflammatory changes in the heart and aorta of normocholesterolemic C57BL/6J mice. Infect Immun 2000;68(8):4765-8.

25. Ezzahiri R, Stassen F, Kurvers H, van Pul M, Kitslaar P, Bruggeman C. Chlamydia pneumoniae infection induces an unstable atherosclerotic plaque phenotype in LDL-receptor, ApoE double knockout mice. European Journal of Vascular and Endovascular Surgery 2003;26(1):88-95.

26. de Kruif MD, van Gorp EC, Keller TT, Ossewaarde JM, ten Cate H. Chlamydia pneumoniae infections in mouse models: relevance for atherosclerosis research. Cardiovasc Res 2005;65(2):317-27.

27. Maass M, Bartels C, Engel PM, Mamat U, Sievers HH. Endovascular presence of viable Chlamydia pneumoniae is a common phenomenon in coronary artery disease. J Am Coll Cardiol 1998;31(4):827-32.

28. Maass M, Bartels C, Kruger S, Krause E, Engel PM, Dalhoff K. Endovascular presence of Chlamydia pneumoniae DNA is a generalized phenomenon in atherosclerotic vascular disease. Atherosclerosis 1998;140 Suppl 1:S25-30.

29. Petersen E, Boman J, Persson K, Arnerlov C, Wadell G, Juto P, et al. Chlamydia pneumoniae in human abdominal aortic aneurysms. Eur J Vasc Endovasc Surg 1998;15(2):138-42.

30. Taylor-Robinson D, Thomas BJ. Chlamydia pneumoniae in atherosclerotic tissue. J Infect Dis 2000;181 Suppl 3:S437-40.

31. Ramirez JA. Isolation of Chlamydia pneumoniae from the coronary artery of a patient with coronary atherosclerosis. The Chlamydia pneumoniae/Atherosclerosis Study Group. Ann Intern Med 1996;125(12):979-82.

32. Gieffers J, Solbach W, Maass M. In vitro susceptibilities of Chlamydia pneumoniae strains recovered from atherosclerotic coronary arteries. Antimicrob Agents Chemother 1998;42(10):2762-4.

33. Jackson LA, Campbell LA, Kuo CC, Rodriguez DI, Lee A, Grayston JT. Isolation of Chlamydia pneumoniae from a carotid endarterectomy specimen. J Infect Dis 1997;176(1):292-5.

34. Kalayoglu M, Byrne GI. Induction of macrophage foam cell formation by Chlamydia pneumoniae. J. Infect. Dis. 1998;177:725-729. 
35. Kaukoranta-Tolvanen SS, Ronni T, Leinonen M, Saikku P, Laitinen K. Expression of adhesion molecules on endothelial cells stimulated by Chlamydia pneumoniae. Microb Pathog 1996;21(5):407-11.

36. Molestina R, Miller R, Ramirez J, Summersgil J. Infection of human endothelial cells with Chlamydia pneumoniae stimulates transendothelial migration of neutrophils and monocytes. Infect. Immun. 1999;67:1323-1330.

37. Coombes BK, Mahony JB. Chlamydia pneumoniae infection of human endothelial cells induces proliferation of smooth muscle cells via an endothelial cell-derived soluble factor(s). Infect Immun 1999;67(6):2909-15.

38. Fryer R, Scwobe E, Woods M, Rodgers M. Chlamydia species infect human vascular endothelial cells and induce procoagulant activity. J. Invest. Med. 1997;45:168-174.

39. Dechend R, Maass M, Gieffers J, Dietz R, Scheidereit C, Leutz A, et al. Chlamydia pneumoniae infection of vascular smooth muscle and endothelial cells activates NF-kappaB and induces tissue factor and PAI-1 expression: a potential link to accelerated arteriosclerosis. Circulation 1999;100(13):1369-73.

40. Kol A, Sukhova GK, Lichtman AH, Libby P. Chlamydial heat shock protein 60 localizes in human atheroma and regulates macrophage tumor necrosis factor-alpha and matrix metalloproteinase expression. Circulation 1998;98(4):300-7.

41. Nakashima Y, Plump AS, Raines EW, Breslow JL, Ross R. ApoE-deficient mice develop lesions of all phases of atherosclerosis throughout the arterial tree. Arterioscler Thromb 1994;14(1):133-40.

42. Lutgens E, Daemen M, Kockx M, Doevendans P, Hofker M, Havekes L, et al. Atherosclerosis in $\mathrm{APOE}^{\star} 3$-Leiden transgenic mice: from proliferative to atheromatous stage. Circulation 1999;99(2):276-83.

43. de Bont N, Netea MG, Demacker PN, Verschueren I, Kullberg BJ, van Dijk KW, et al. Apolipoprotein E knock-out mice are highly susceptible to endotoxemia and Klebsiella pneumoniae infection. J Lipid Res 1999;40(4):680-5.

44. Roselaar SE, Daugherty A. Apolipoprotein E-deficient mice have impaired innate immune responses to Listeria monocytogenes in vivo. J Lipid Res 1998;39(9):1740-3.

45. Netea MG, Demacker PN, Kullberg BJ, Boerman OC, Verschueren I, Stalenhoef AF, et al. Low-density lipoprotein receptor-deficient mice are protected against lethal endotoxemia and severe gram-negative infections. J Clin Invest 1996;97(6):1366-72.

46. Netea MG, Demacker PN, de Bont N, Boerman OC, Stalenhoef AF, van der Meer JW, et al. Hyperlipoproteinemia enhances susceptibility to acute disseminated Candida albicans infection in low-density-lipoprotein-receptor-deficient mice. Infect Immun 1997;65(7):2663-7.

47. Kuller LH, Tracy RP, Shaten J, Meilahn EN. Relation of C-reactive protein and coronary heart disease in the MRFIT nested case-control study. Multiple Risk Factor Intervention Trial. Am J Epidemiol 1996;144(6):537-47.

48. Ridker PM, Rifai N, Stampfer MJ, Hennekens $\mathrm{CH}$. Plasma concentration of interleukin-6 and the risk of future myocardial infarction among apparently healthy men. Circulation 2000;101(15):1767-72.

49. Rost NS, Wolf PA, Kase CS, Kelly-Hayes M, Silbershatz H, Massaro JM, et al. Plasma concentration of C-reactive protein and risk of ischemic stroke and transient ischemic attack: the Framingham study. Stroke 2001;32(11):2575-9.

50. Ridker PM, Cushman M, Stampfer MJ, Tracy RP, Hennekens CH. Plasma concentration of C-reactive protein and risk of developing peripheral vascular disease. Circulation 1998;97(5):425-8. 
51. Cermak J, Key NS, Bach RR, Balla J, Jacob HS, Vercellotti GM. C-reactive protein induces human peripheral blood monocytes to synthesize tissue factor. Blood 1993;82(2):513-20.

52. Galve-de Rochemonteix B, Wiktorowicz K, Kushner I, Dayer JM. C-reactive protein increases production of IL-1 alpha, IL-1 beta, and TNF-alpha, and expression of mRNA by human alveolar macrophages. J Leukoc Biol 1993;53(4):439-45.

53. Vainas T, Lubbers T, Stassen FR, Herngreen SB, van Dieijen-Visser MP, Bruggeman CA, et al. Serum C-reactive protein level is associated with abdominal aortic aneurysm size and may be produced by aneurysmal tissue. Circulation 2003;107(8):1103-5.

54. Yasojima K, Schwab C, McGeer EG, McGeer PL. Generation of C-reactive protein and complement components in atherosclerotic plaques. Am J Pathol 2001;158(3):1039-51.

55. Torzewski J, Bowyer DE, Waltenberger J, Fitzsimmons C. Processes in atherogenesis: complement activation. Atherosclerosis 1997;132(2):131-8.

56. Seifert PS, Kazatchkine MD. The complement system in atherosclerosis. Atherosclerosis 1988;73(2-3):91-104.

57. Nagpurkar A, Hunt D, Yang CY, Mookerjea S. Degradation of rat C-reactive protein by macrophages. Biochem J 1993;295 ( Pt 1):247-53.

58. Mookerjea S, Francis J, Hunt D, Yang CY, Nagpurkar A. Rat C-reactive protein causes a charge modification of LDL and stimulates its degradation by macrophages. Arterioscler Thromb 1994;14(2):282-7.

59. Gates CA, Rees RS. Serum amyloid P component: its role in platelet activation stimulated by sphingomyelinase $D$ purified from the venom of the brown recluse spider (Loxosceles reclusa). Toxicon 1990;28(11):1303-15.

60. Marathe S, Choi Y, Leventhal AR, Tabas I. Sphingomyelinase converts lipoproteins from apolipoprotein $\mathrm{E}$ knockout mice into potent inducers of macrophage foam cell formation. Arterioscler Thromb Vasc Biol 2000;20(12):2607-13. 


\section{CHAPTER 5}

Unstable atherosclerotic lesions and premature death in LDL-receptor, ApoE double knockout mice following Chlamydia pneumoniae infection

Rajaa Ezzahiri, ${ }^{1}$ Frank RM Stassen, ${ }^{2}$ Marion JJ Gijbels, ${ }^{3}$ Harrie AJM Kurvers, ${ }^{1}$ Gert ELM Grauls, ${ }^{2}$ Marloes ML van Pul, ${ }^{2}$ Peter JEHM Kitslaar, ${ }^{1}$ Cathrien A Bruggeman. ${ }^{2}$

Department of Surgery, ${ }^{1}$ Medical Microbiology, ${ }^{2}$ and Molecular Genetics, ${ }^{3}$ University Hospital Maastricht, the Netherlands.

Partly published in Eur J Vasc Endovasc Surg. 2003 Jul;26(1):88-95 


\begin{abstract}
Objective: Infections have been linked with progression of atherosclerosis. To study whether Chlamydia pneumoniae (Cpn) affects atherosclerosis, we infected atherogenic mice and studied plaque characteristics.

Methods: Mice were infected with Cpn or mock and sacrificed at 20 or 40 weeks of age or observed until natural death. Aortic arch sections were analyzed for lesion area, type, fibrous cap area, necrotic core content, collagen content, matrix metalloproteinases (MMP)-2 and -9 , and signs of plaque rupture.

Results: All infected mice seroconverted and Cpn DNA was detected in the aorta of all infected mice. All mice developed atherosclerotic lesions from type 2 to $5 \mathrm{~b}$. Although infection did not affect lesion area or type, it significantly reduced the fibrous cap, increased necrotic core, and increased the presence of MMP-2 and -9 in Cpn-infected mice sacrificed at 20 and 40 weeks of age. MMP activity and mRNA expression did not differ between these groups. Furthermore, Cpn infection resulted in a decrease in survival when mice were followed until nature death occurred. Both groups showed equal numbers of animals with cardiovascular complications.

Conclusion: We demonstrate that Cpn infection has no effect on lesion area or type in the aortic arch of ApoE-/-LDLr-/-mice. However, Cpn infection resulted in reduced fibrous cap thickness, increased necrotic core content, and a reduction in survival probably due to cardiovascular complications. These findings suggest that Cpn infection alters the plaque phenotype from stable to vulnerable and may provide an explanation for the previously observed correlation between myocardial infarction and Cpn.
\end{abstract}




\section{Introduction}

Key steps in the initiation of atherogenesis involve activation of the endothelium (e.g. by hypercholesterolemia), influx of leucocytes in the sub-endothelial layer and maintenance of the inflammatory state by production of pro-inflammatory cytokines by these leucocytes. Intriguingly, infections may initiate and/or stimulate most of these key events thereby adding themselves to the long list of potential risk factors. In particular Chlamydia pneumoniae (Cpn), an obligate intracellular gram negative bacterium, has frequently been associated with cardiovascular diseases. Sero-epidemiological $^{1,2}$ as well as experimental in vivo ${ }^{3,4}$ and in vitro ${ }^{5,6}$ studies have demonstrated an association between $\mathrm{Cpn}$ and atherosclerosis. Furthermore, we recently demonstrated that $\mathrm{Cpn}$ infection stimulates the inflammatory activity in atherosclerotic plaques of ApoE3* ${ }^{*}$ eiden mice. ${ }^{7}$ This invigorating effect on plaque inflammation may in the long run result in plaque destabilization and rupture. Earlier data demonstrated that the production of matrix metalloproteinases (MMPs) by both macrophages and smooth muscle cells is upregulated by $\mathrm{Cpn}$, suggesting that these bacteria actively participate in the destruction of the extracellular matrix. ${ }^{8,9}$ Furthermore, increased immunoreactivity and gelatinolytic activity of MMP-2 and -9 were observed in Cpn positive human atheroma..$^{10,11}$

Based on these earlier observations, we hypothesized that Cpn infection increases vascular inflammation as well as MMP expression and activity, resulting in a modification of the plaque phenotype towards an unstable one, eventually plaque rupture with subsequent myocardial infarction and finally death. To explore this hypothesis, Apolipoprotein E, low density lipoprotein receptor double knockout (ApoE-/-LDLr-/-) mice were infected with $\mathrm{Cpn}$ and the effect on plaque characteristics was studied. Furthermore, MMP immunoreactivity, expression, and activity were determined in the aortic arch following $\mathrm{Cpn}$ infection. Also survival characteristics following multiple $\mathrm{Cpn}$ infections were determined.

\section{Methods}

\section{Mice}

Eighty-six male specific pathogen free (SPF) ApoE-/-LDLr-/- mice on a C57BI/6J background were used. Mice were housed under standard conditions at the Central Animal Facility of the Maastricht University and fed a normal chow diet (Hopefarms BV, Woerden, The Netherlands) and water ad libitum. All experiments were performed according to the institutional guidelines of the committee for the welfare of laboratory animals of the Maastricht University.

\section{Chlamydia pneumoniae (Cpn)}

Cpn strain TWAR 2043 (ATCC VR-1355) was cultured in Hep-2 cells as described previously. ${ }^{12}$ Bacterial titers were determined by titration in Hep-2 cells and stained with 
fluorescein-isothiocyanate-conjugated (FITC) monoclonal antibody RR 402 (Dako, Glostrup, Denmark) directed against elementary bodies of Cpn. Titers were expressed as number of inclusion forming units per milliliter (IFU/ml). ${ }^{7}$

\section{Study design}

In humans, multiple Cpn infections occur throughout one's lifetime. Therefore, we infected mice 2 or 6 times starting at the age of 16 weeks by an intraperitoneal injection with Cpn (5.107 IFU) containing sucrose-phosphate-glucose (SPG) solution, while control mice (mock) received SPG only. The intraperitoneal inoculation route was chosen over intranasal injection since previous studies from our group had shown that systemic dissemination, analysed by real time PCR analysis, following intraperitoneal Cpn infection compared with intratracheal infection was not different(manuscript in preparation). Mice in group A received a second inoculation, 5.106 IFU Cpn or mock, $(n=8 \quad C p n / n=8$ mock) at the age of 18 weeks and were sacrificed at the age of 20 weeks. Mice in group $B,(n=7 / 7)$ received 6 monthly infections (first infection with 5.107 IFU Cpn and following infections with 5.106 IFU Cpn) or mock injections and were sacrificed 1 month after the last injection (at the age of 40 weeks). Mice in group $C(n=7 / 7)$ also received 6 successive monthly infections or mock injections, starting at the age of 16 weeks, and were observed until natural death had occurred. Post mortem examination was performed by an experienced pathologist specialized in animal pathology. Additionally 40 mice were included for analysis of MMP-2 and -9 expression (mRNA, $n=10 / 10$ ) and activity (zymography, $n=10 / 10$ ). These mice received the same inoculation protocol as mice in group $\mathrm{A}$.

\section{Tissue handling}

Before sacrifice, mice were anaesthetized with a weight-adjusted dose of pentobarbital (Nembutal , Sanofi BV, Maassluis, The Netherlands) and blood was collected from the left ventricular apex of the heart for analysis of anti-Cpn antibodies. ${ }^{7}$ Then the arterial tree was perfused with phosphate-buffered saline (PBS) through a catheter placed in the left ventricular apex. From the mice in group $A$ and $B$, the aortic arch with main branch points was removed, fixed overnight in 3.7\% PBS buffered formaldehyde and embedded in paraffin. Serial longitudinal $4 \mu \mathrm{m}$ sections of the aortic arch were cut, stained and analyzed. The remainder of the aorta (thoracic and abdominal), lung, spleen, heart and brain were dissected and stored at $-70^{\circ} \mathrm{C}$ for $\mathrm{Cpn}$ DNA analysis. For analysis of MMP-2 and -9 mRNA expression and gelatinolytic activity, the aortic arch with its main branch points was removed, frozen in liquid nitrogen and stored at $-70^{\circ} \mathrm{C}$.

\section{Detection of anti-Cpn antibodies and Cpn DNA}

To check whether the inoculation protocols were successful, the presence of anti-Cpnantibodies was determined in mouse plasma with the indirect micro-immunofluorescence (MIF) technique as described previously. ${ }^{13}$ Mouse plasma dilutions 1:10 and 1:100 were applied on antigen-coated slides (Labsystems, Helsinki, Finland). Sections were then incubated with goat-anti-mouse IgG conjugated to FITC (Dako, Glostrup, 
Denmark) and analyzed by 2 independent observers. Furthermore, a sensitive (detection limit 1 copy of DNA) in house developed polymerase chain reaction (PCR) test was used to detect $\mathrm{Cpn}$ DNA in various organs. The following sequences were used as primers: sense CPC, 5'-TTA TTA ATT GAT GGT ACA ATA-3'; antisense CPD, 5'ATC TAC GGC AGT AGT ATA GTT- $3 .{ }^{\prime}{ }^{14}$ These primers specify MOMP of Cpn. PCR was performed in a total volume of $50 \mu \mathrm{l}$, containing $1 \mu \mathrm{g}$ DNA. DNA was extracted from vascular tissue with the Wizard Genomic DNA purification kit (Promega, Germany). Amplification was done by thermal cycling starting at $37^{\circ} \mathrm{C}$ for ten minutes and $95^{\circ} \mathrm{C}$ for fifteen minutes. Then 20 cycles of "Touchdown PCR" were performed from $60^{\circ} \mathrm{C}$ to $50^{\circ} \mathrm{C}$, followed by 40 cycles of 1 minute at $94^{\circ} \mathrm{C}, 50^{\circ} \mathrm{C}$, and $72^{\circ} \mathrm{C}$.

The PCR products were resolved in a $2 \%$ agarose gel, stained with ethidium bromide, and photographed

\section{Atherosclerotic lesion analysis}

The whole aortic arch from every mouse was cut in longitudinal, coronal, consecutive sections and used for analysis of atherosclerotic lesion type and lesion area. Only arches with an intact morphology (brachiocephalic trunk, left and right common carotid artery and left subclavian artery) were used in the study. The number of sections obtained from each aortic arch was calculated and the middle section was haematoxilin-eosin (HE) stained for analysis of atherosclerotic lesion types according to the guidelines of the American Heart Association. ${ }^{7,15-17}$ The total number of all lesions was measured and the contribution of each lesion type to the total number of lesions was expressed as a percentage of the total lesion number. For determination of total lesion area the same HE-stained section was used. Lesion area was measured using a microscope coupled to a computer-assisted morphometry system (Analysis Soft Imaging System, GmbH, Münster, Germany). ${ }^{7}$

\section{Immunohistochemistry}

For detection of smooth muscle cells (SMC) and to analyze the presence of matrix metalloproteinase (MMP) -2 and -9 in the atherosclerotic lesion, -smooth muscle cell actin (Sigma, St. Louis, USA) and MMP-2 and -9 (Oncogene Research Products, Cambridge, UK) mouse monoclonal antibody were used. The primary antibody was probed with biotin labeled goat-anti-mouse lgG. Sections were incubated with an alkaline phosphatase coupled ABC reagent (Dako, Glostrup, Denmark) and alkaline phosphatase activity was visualized using Fast-red (Sigma, St. Louis, USA). For negative control, normal mouse ascitic fluid (Sigma-Aldrich Chemie BV, Zwijndrecht, The Netherlands) was used. Since the media of the vascular wall mainly consists of SMC, this part of the slide was used as positive control for - actin staining. Since cardiomyocytes are known to contain MMP-2 and -9, mouse heart sections were used as positive controls for the MMP immunolabeling.

For quantification of fibrous cap area in the atherosclerotic lesion, non-media SMC positive area was analyzed using a microscope coupled to a computer assisted morphometry system (Analysis Soft Imaging System, GmbH, Münster, Germany). The 
results were expressed as area SMC/total lesion area and are designated as cap area. MMP-2 and -9 immunoreactivity was analyzed by semi-quantitative measurements using 0 when no staining was visible, 1 when positive staining was observed and 2 when extensive positive staining was seen. Mean score of all aortic arch sections was calculated and results of Cpn-infected and control mice were compared.

\section{Collagen content of the plaque}

To evaluate the collagen content of the lesion, Sirius red staining was used. ${ }^{18,19}$

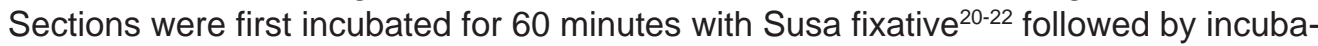
tion with $0.1 \%$ Sirius red solution (Klinipath, Duiven, The Netherlands) in saturated picric acid for 30 minutes. After incubation with $0.01 \mathrm{~N} \mathrm{HCl}$ for 2 minutes, sections were stained with hematoxylin staining for 6 minutes. Liver mouse sections were used as positive control. For quantification of collagen content of the plaque, Sirius red positive area in the atherosclerotic lesion was analysed using a microscope coupled to a computer assisted morphometry system (Analysis Soft Imaging System, GmbH, Münster, Germany) and Scion Image Release Beta 3b (Scion Corporation, Frederick, Maryland, USA). The results were expressed as area collagen/total lesion area and are designated as percentage collagen of total lesion.

\section{Lipid core evaluation of the atherosclerotic lesions}

The lipid core area was measured in the atherosclerotic lesions that contained lipid cores using a microscope coupled to a computer assisted morphometry system (Analysis Soft Imaging System, GmbH, Münster, Germany) and expressed as percentage lipid core of the total lesion.

MMP-2 and -9 mRNA expression in the atherosclerotic aortic arch

To study the presence of MMP-2 and -9 mRNA in the aortic arch lesions of ApoE-/LDLr-/- mice, real-time RT-PCR was used. Vascular tissue was homogenized and total RNA was isolated using the TRIzol ${ }^{\boxplus}$ Reagent from Life Technologies, Paisley, United Kingdom for samples with high protein content. DNase treatment with DNase I (0.362U, Amersham Pharmacia Biotech) was performed and equal amounts of total RNA were reverse transcribed into cDNA using oligo dT (RACE-1, 1 pmol, Amersham Pharmacia Biotech) and Superscript II RNAseH- (25U, Invitrogen). For every total RNA isolate also a RT-PCR reaction was performed in the absence of the reverse transcriptase, to demonstrate the specific amplification of mRNA instead of genomic DNA. Real-time PCR reactions on CDNA were performed by the ABI Prism 7000 in a final volume of $25 \mathrm{I}$. Primers and probes for the detection of MMP-2 were: forward primer 5'-CTATGTCCACTGTGGGTGGAAAT-3'(300nM), reverse primer 5'CTTGTTGCCCAGGAAAGTGAA-3' $(900 \mathrm{Nm})$ and probe 5'-CAGAAGGTGCCCCATGTGTCTTCCC-3' (200nM). The probe carried a 5' FAM reporter and a 3' TAMRA quencher group. Thermal cycling started with UNG activation for 2 minutes at $50^{\circ} \mathrm{C}$, followed by HotStarTaq activation during 10 minutes at $95^{\circ} \mathrm{C}$. Thereafter 42 cycles of amplification were run consisting of 15 seconds at $95^{\circ} \mathrm{C}$ and 1 minute at $60^{\circ} \mathrm{C}$. To 
amplify GAPDH the Taqman ${ }^{\circledR}$ Rodent GAPDH Control Reagents kit (Applied Biosystems, Foster City, United States) was used. For amplification of MMP-9 the primers 5'-GACCCGAAGCGGACATTG-3' (300nM, forward primer) and 5'-TGCCGTCGAAGGGATACC-3 (900nM, reverse primer) and the probe 5'-ATCCAGTTTGGTGTCGCGGAGCA-3' (200 nM, VIC and TAMRA labelled) were used. Relative differences in the expression of MMP-2 and MMP-9 mRNA levels in the two groups were determined by dividing for every sample the mean Ct ("threshold cycle") value of GAPDH by the mean Ct value of MMP-2 or -9. Every sample was measured in duplo. This method was used to compensate for possible fluctuations in total RNA input in the real-time RT-PCR.

\section{MMP-2 and -9 gelatinolytic activity}

To study MMP-2 and -9 activity in atherosclerotic lesions, the zymography technique, the "golden standard" for analysis of MMP-2 and -9 activity, was used. ${ }^{23}$ The aortic arch was weighed, cut into small pieces and incubated in extraction buffer $(10 \mathrm{mM}$ cacodylic acid ( $\mathrm{pH} 5.0), 0.15 \mathrm{mM} \mathrm{NaCl}, 1 \mathrm{M} \mathrm{ZnCl} 2,20 \mathrm{mM} \mathrm{CaCl} 2,1.5 \mathrm{mM} \mathrm{NaN3}$ and $0.01 \%$ Triton X-100) at a concentration of $10 \mathrm{l} / \mathrm{mg}$ wet weight at $4^{\circ} \mathrm{C}$. Then, samples were agitated continuously for 48 hours, extraction buffer was collected and $1 \mathrm{M}$ Tris $(\mathrm{pH}$ 8.0) was added to adjust the $\mathrm{pH}$ to 7.5. Protein concentration of the supernatant was determined using Bio-Rad protein assay (Bio-Rad Laboratories $\mathrm{GmbH}$, München, Germany). Determination of MMP-2 and -9 activity was visualised using zymographic analysis on a gelatin-containing gel. Of every vascular tissue extract $30 \mu \mathrm{g}$ of protein was loaded onto electrophoretic gels (SDS-PAGE) containing $1 \mathrm{mg} / \mathrm{ml}$ gelatin as described by Silence et al. ${ }^{24}$ MMP-2 and -9 activity was quantified by measuring integrated optical densities of the lytic bands (Gel-Pro Analyzer v2.0).

\section{Post mortem analysis of mice}

Mice, included in group C ( $n=7 / 7)$, were inoculated with 6 monthly injections of $C p n$ or mock and observed until natural death had occurred. Post mortem examination was performed by an experienced pathologist specialized in animal pathology (MG). Consecutive sections of heart, lung, brain, liver, aortic arch and spleen were cut, stained with hematoxylin-eosin or Martius Scarlet Blue and screened for signs of plaque rupture, myocardial infarcts or other possible causes of death.

\section{Statistical analysis}

Difference in lesion type, size, fibrous cap, collagen, lipid core, MMP-2 and -9 expression, activity, and immunoreactivity between the Cpn-infected and control mice were analyzed with the Mann-Whitney-U test.

Differences in survival between $\mathrm{Cpn}$-infected and control mice of group $\mathrm{C}$ were analyzed by Kaplan-Meier and log rank test. A p-value of $<0.05$ was considered statistically significant. Results are expressed as mean \pm SEM. Analysis of sections was done by an observer who was blinded with respect to the presence or absence of $\mathrm{Cpn}$ as well as to the time point of sacrifice. 


\section{Results}

Of the 86 male ApoE-/-LDLr-/- mice used in the study, 2 mice in group B (one Cpninfected and one control mouse) died before reaching time point of sacrifice. These mice were excluded from the study, the cause of death remained unknown.

\section{Presence of anti-Cpn antibodies and Cpn DNA}

All Cpn-infected mice developed anti-Cpn antibodies at plasma dilutions of 1:10 and 1:100, indicating that mice had indeed been successfully infected. No anti-Cpn antibodies were detected in plasma of control mice. These results were confirmed by data obtained from Cpn PCR. Cpn DNA was detected in all aortic samples of group A showing that intra-peritoneal infection resulted in dissemination of $\mathrm{Cpn}$ to the vessel wall in all cases. Cpn DNA could also be detected in various other organs (spleen 100\%, lung $86 \%$, heart $57 \%$ and brain tissue $29 \%$ of the samples positive for Cpn DNA). In group $\mathrm{B}$ (sacrificed 1 month after the last infection), the percentage of $\mathrm{Cpn}$ positive aortic samples was slightly lower compared to group A (43\% vs $100 \%)$ indicating that the immune system of the mouse is able to eradicate $\mathrm{Cpn}$ in the long run. In a similar way lower percentages of Cpn DNA positive organs were observed in group B (data not shown). No positive results were obtained in the mock infected group.

Cpn infection has no effect on atherosclerotic lesion type or lesion area The aortic arches of mice in group $A$ and $B$ all contained atherosclerotic lesions ranging from type 2 (foam cell rich lesions) to type $5 b$ (advanced calcified) lesions. In group $B$ (sacrifice at 40 weeks of age) more advanced lesion types, especially type $5 b$, were found when compared to group A (sacrifice at 20 weeks of age) where type 4 and $5 \mathrm{a}$ lesions were predominant. This finding confirms earlier observations that the complexity of the atherosclerotic lesion types increases with time. ${ }^{7,15}$ Nevertheless, no statistically significant difference was found in the distribution of different lesion types between Cpn-infected and control mice in both group A and B. Similarly, no effect of Cpn infection on lesion area could be detected, either in group A or B. (Group A, mock: $0.22 \pm 0.03 \mathrm{~mm}^{2}$ vs. Cpn: $0.24 \pm 0.03 \mathrm{~mm}^{2}$, NS. Group B, mock: $0.75 \pm 0.09$ $\mathrm{mm}^{2}$ vs. Cpn: $0.66 \pm 0.08 \mathrm{~mm}^{2}$, NS). Like lesion type, lesion area increases with time when control mice in group A and group B, and Cpn-infected mice of group A and B were compared.

These data indicate that $\mathrm{Cpn}$ infection does not affect atherosclerotic lesion type or lesion area in ApoE-/-LDLr-/- mice when these mice are infected at a stage when advanced atherosclerotic lesions are already present.

\section{Cpn infection induces an unstable plaque phenotype}

\section{Fibrous cap and lipid core area}

The fibrous cap and lipid core area, as well as the collagen content, were expressed as a percentage of the total lesion area. Positive staining for $\alpha$-smooth muscle cell 
actin was restricted to the fibrous cap of the atherosclerotic lesion with very few diffuse staining in the rest of the plaque. ${ }^{16}$ When the percentage of fibrous cap areas in Cpn-infected and control mice of group A were compared, a reduction was observed in the Cpn infected group (mock:.26\% $\pm 3 \%$ vs. Cpn: $9 \% \pm 3 \%, p<0.001$, figure $1 A$ ). Likewise, a reduction was seen following multiple infections (group B: mock: $10 \% \pm$ $1 \%$ vs. Cpn $5 \% \pm 2 \%, p<0.01$, figure $1 \mathrm{~A}$ ). When percentages of control mice in group $A$ and group $B$ were compared, a reduction from $26 \% \pm 3 \%$ in group $A$ to $10 \% \pm 1 \%$ in group $B(p<0.001)$ was observed. Furthermore, when the percentage of lipid core area was studied an increase in the percentage of the lipid core was seen in Cpninfected mice from groups (group A: $12 \% \pm 2 \%$ (mock) vs. $24 \% \pm 3 \%$ (Cpn), $p<0.001$; Group B: $6 \% \pm 1 \%$ (mock) vs. 9\% $\pm 1 \%$ (Cpn), p<0.01, figure1B).

To determine the percentage of collagen, aortic arch sections were stained with Sirius red. All atherosclerotic lesions contained collagen as shown by a positive Sirius red staining. Nevertheless, no differences in percentage of collagen in the plaque was observed after either 2 or 6 Cpn infections (table 1).

In summary, Cpn reduced the percentage of fibrous cap and increased the lipid core. These results suggest that Cpn infection reduces the stability of the atherosclerotic plaque in these mice, despite the absence of changes in collagen percentage.

Table 1: Collagen percentage, MMP-2 and -9 antigen and $m R N A$ in the plaque. Collagen is expressed as collagen percentage of total lesion area MMP-2 and -9 mRNA expression is designated as GAPDH/MMP2 or GAPDH/MMP-9. \#p<0.005 vs. control .

\begin{tabular}{lcccc}
\hline & \multicolumn{2}{c}{ Group A $(\mathrm{n}=8 / 8)$} & \multicolumn{2}{c}{ Group B (n=7/7) } \\
& Control & Cpn & Control & Cpn \\
\hline Collagen content & $59 \% \pm 2 \%$ & $59 \% \pm 1 \%$ & $64 \% \pm 1 \%$ & $62 \% \pm 1 \%$ \\
MMP-2 antigen & $0.83 \pm 0.18$ & $\# 1.50 \pm 0.24$ & $1.00 \pm 0.00$ & $\# 1.43 \pm 0.22$ \\
MMP-9 antigen & $0.25 \pm 0.17$ & $\# 0.75 \pm 0.17$ & $0.57 \pm 0.22$ & $0.86 \pm 0.15$ \\
MMP-2 mRNA & $0.86 \pm 0.01$ & $0.86 \pm 0.01$ & ND & ND \\
MMP-9 mRNA & $0.63 \pm 0.00$ & $0.62 \pm 0.01$ & ND & ND \\
\hline
\end{tabular}

Role of matrix metalloproteinase-2 and -9 in Cpn-induced plaque destabilization Since previous reports have suggested a role for MMPs in plaque destabilization, possibly by extracellular matrix degradation, we studied the presence, expression and activity of two important candidates (MMP-2 and -9 ) in this respect. 
Figure 1. A: Fibrous cap percentage in atherosclerotic lesions of $\mathrm{Cpn}$-infected and control mice of groups $\mathrm{A}$ and $B$. The values are presented as percentage SMC area of total plaque area. $\# p<0.001$ vs. control in group $A,{ }^{*} p<0.01$ vs. control in group $B$.

B: Necrotic core percentage in atherosclerotic lesions of Cpn-infected and control mice of groups A and B. Necrotic core is expressed as percentage necrotic core of the total plaque area. $\# p<0.001$ vs. control in group $A,{ }^{*} p<0.01$ vs. control in group $B$.

A

CAP AREA IN PLAQUE

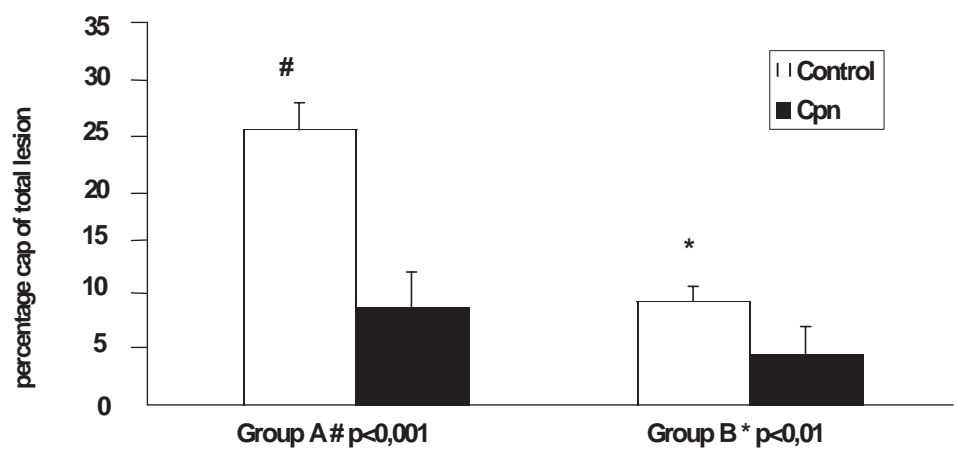

B

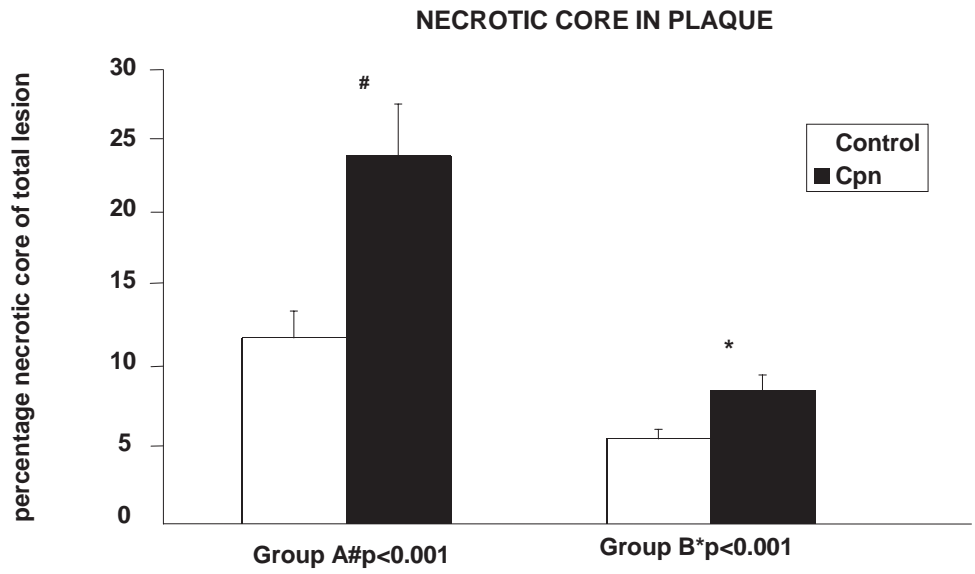

MMP-2 and -9 antigens in the plaque

Presence of MMP antigens was shown by immunohistochemical stainings. Positive staining was mainly concentrated in the endothelial layer, lipid core and shoulder region of the atherosclerotic lesion. When the presence of MMP-2 and -9 antigen in Cpn-infected and control mice of group A and B was compared in a semi-quantitative way, an increase in MMP-2 and MMP-9 immunoreactivity was observed in Cpn-infected mice. MMP-2 positive staining was detected more frequently $(1.5 \pm 0.24)$ in Cpn- 
infected mice from group $A$ than in control mice $(0.83 \pm 0.18, p<0.05)$. Similar results were obtained in mice of group $B$. In this group MMP-2 positive staining was more frequently observed in Cpn-infected mice $(1.43 \pm 0.22)$ than in control mice (1.00 $\mathrm{p}<0.05)$. Furthermore, in group $A, M M P-9$ positive staining increased from $0.25 \pm 0.17$ in control mice to $0.75 \pm 0.17$ in Cpn-infected mice $(p<0.05$, table 1$)$, while in group $B$ MMP-9 positive staining was $0.57 \pm 0.22$ in control mice and $0.86 \pm 0.15$ in Cpn-infected mice (NS).

\section{MMP-2 and -9 mRNA expression}

Since the increase in MMP antigens was more pronounced at the age of 20 weeks (group A) as compared to group B (sacrificed at the age of 40 weeks), we determined the expression of MMP-2 and -9 mRNA in the aortic arch of ApoE-/-LDLr-/- mice at this time point either following Cpn infection or mock injection. All aortic arch samples showed presence of MMP-2 and -9 mRNA. Nonetheless, no significant difference in MMP-2 and -9 mRNA expression was observed between Cpn infected and control mice (NS, table 1).

\section{Gelatinolytic activity}

To study the effect of Cpn infection on MMP-2 and -9 activity, aortic arches of 20 ApoE/- LDLr-/- mice were used for gelatinolytic analysis (figure 2). Quantification of the intensity of the bands demonstrated no differences in the intensities between both groups. Also, pro MMP-2 and -9 (latent form of MMP-2 and -9) activity did not differ between Cpn-infected and control mice (data not shown).

Figure 2. Gelatin zymograpy, demonstrating MMP-2 and -9 activity in aortic arches of Cpn-infected (lane 14) and control (lane 5-6) mice. The top bands represent pro-mmp-9 (94 kDa) and mmp-9 (83 kDa) while the bands with molecular weight $\sim 66 \mathrm{kDa}$ and $\sim 60 \mathrm{kDa}$ represent pro-mmp-2 and mmp-2 respectively. Lane 7 shows the low molecular weight marker (Biorad Laboratories, Richmond United States).

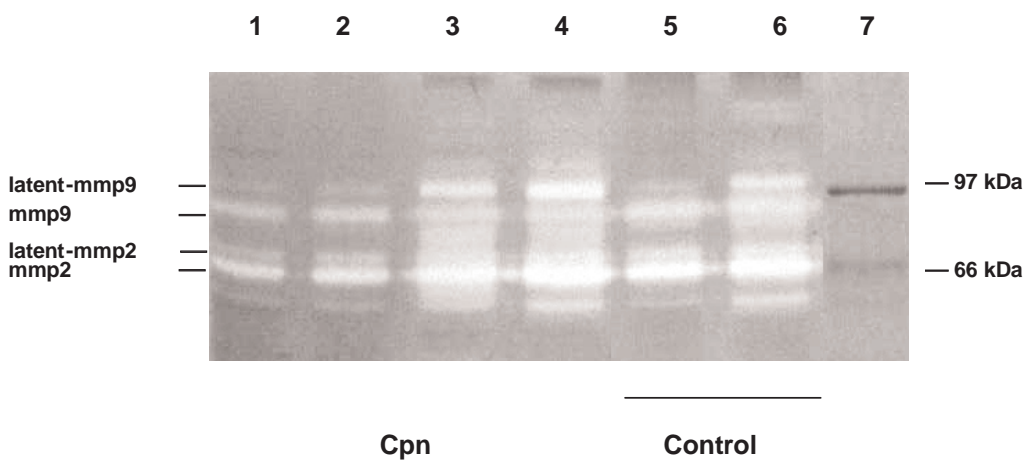


Figure 3. Life table showing survival (days of life) of Cpn-infected $(n=7)$ and control mice ( $n=7)$ of group $C$. ${ }^{*} p=0.02$

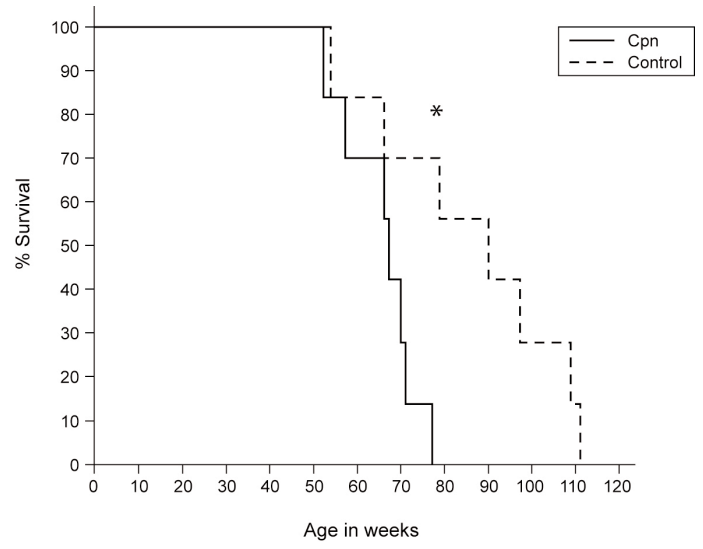

Figure 4. Different characteristics of myocardial infarction.

A: Multifocal areas $(>$ ) of ischemic necrosis. Magnification 100x

B: Fibrosis of septum of the right ventricle. Magnification 100x

C: Severe subendothelial fibrosis of the septum, note the atherosclerosis of the coronary artery ( ).

$\rightarrow$ indicates a non-atherosclerotic coronary artery. Magnification 400x

D: Martius Scarlet Blue staining showing plaque rupture in aortic root of Cpn-infected ApoE-/- ,LDLr-/mouse. Red staining indicates fibrin, yellow staining shows blood coagulates, while collagen is stained blue, magnification 100x
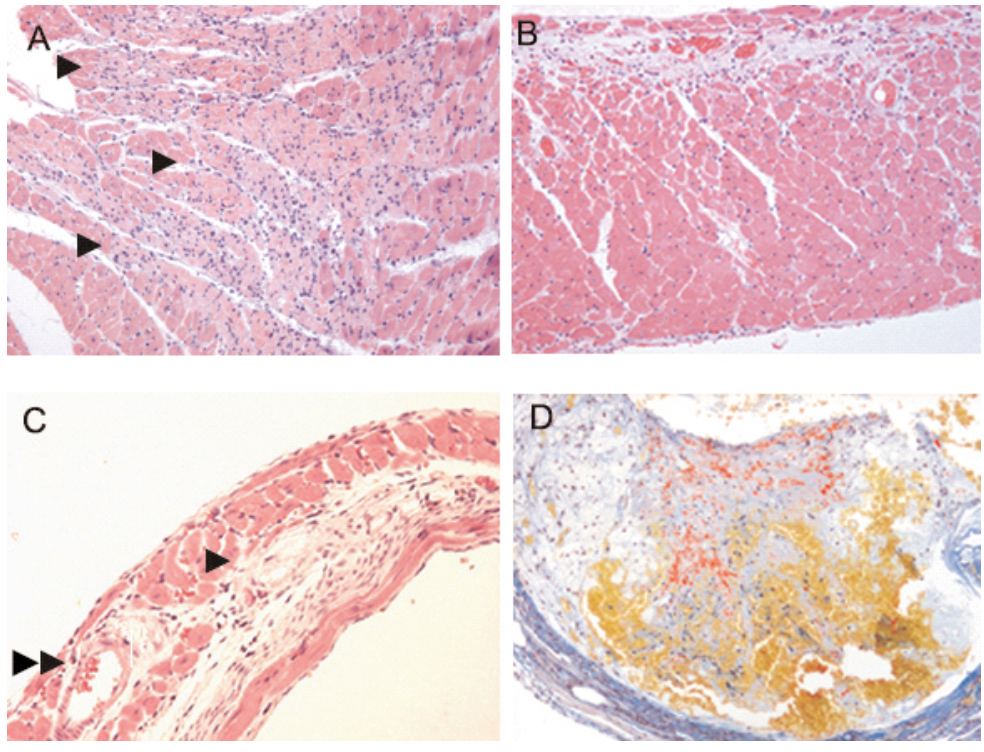
Cpn infection accelerates the incidence of plaque rupture

Since we observed that Cpn infection leads to a reduction of the fibrous cap area and an increase in lipid core content, we were interested whether plaque destabilization due to Cpn infection resulted eventually in the plaque rupture and premature death of the mice. To study this, 14 ApoE-/-LDLr-/- mice were either inoculated with Cpn or mock solution and observed until natural death had occurred. At the time of death, post-mortem histological examination was performed and multiple organs were screened for possible causes of death, such as plaque rupture, myocardial infarction or stroke.

The experiments with mice in group $C$ showed that Cpn-infected mice had a decrease in life span with a mean survival of 86,4 weeks $95 \% \mathrm{Cl}(70.5-102.2)$ in the control mice and 56.8 weeks $95 \% \mathrm{Cl}(59.7-71.9)$ in the Cpn-infected mice (figure 3 ). Histological examination of heart sections showed characteristics of multifocal areas of ischemic necrosis(figure 4A), severe fibrosis of the right ventricle (figure 4B) and severe subendothelial fibrosis of the septum (figure 4C) all characteristics of previous myocardial infarcts. Plaque rupture of aortic root lesions (figure 4D) was also observed, these infarctions were not due to coronary embolism but to atherosclerotic narrowing of the coronary arteries.

\section{Discussion}

This study demonstrates that Cpn does not affect atherogenesis in ApoE-/-LDLr-/- mice with advanced atherosclerotic lesions with respect to total lesion size or type. Nonetheless, we found signs of plaque destabilization following Cpn infection as the fibrotic cap was significantly reduced while lipid cores were markedly increased. As signs of plaque rupture and myocardial infarction were observed in Cpn-infected and control mice at autopsy, we suggest that this accelerated formation of unstable plaques may account for the premature death of mice following multiple Cpn infections.

The large amount of data accumulated in recent years has reinforced the idea that infectious agents play a significant role in the pathogenesis of atherosclerosis and in the clinical manifestations of vascular disease. Sero-epidemiological ${ }^{1,2}$ and experimental data ${ }^{3,25,26}$ from a number of studies have linked Cpn to atherosclerosis. This pathogen may influence atherogenesis through a number of mechanisms, ranging from cell lysis ${ }^{27-29}$ to the stimulation of adhesion molecule expression ${ }^{30}$ and cytokine production ${ }^{31}$ by infected cells. Moreover, we ${ }^{7}$ and others ${ }^{26,32}$ have demonstrated that Cpn promotes atherogenesis in atherosclerotic mice when infected at a young age when normally only initial lesions are present. Invigorating effects on both total lesion area as well as an acceleration in the formation of advanced lesions have been reported. In the present study, however, we did not find any effects of Cpn infection(-s) on either lesion area or lesion type. The reason for this discrepancy may be related to the fact that in 16 week-old ApoE-/-LDLr-/- mice, as used in the present study, advanced lesions are already the predominant phenotype while in younger mice (e.g. 8 week- 
old ApoE3-Leiden used in our earlier study $)^{7}$ initial plaques are the principal phenotype. Initial lesions mainly consist of macrophages infiltrating the vascular wall while advanced lesions contain a large necrotic core with extracellular lipids and cholesterolester crystals, extracellular matrix components (collagen) and smooth muscle cells. As macrophages are used as vehicle by Cpn for dissemination from the site of infection to different organs throughout the whole body (including the vessel wall) ${ }^{33}$, it may be anticipated that it is more easy for $\mathrm{Cpn}$ to enter an initial atherosclerotic plaque and exert its pro-atherogenic effect than to enter an advanced lesion. This may explain why Cpn infections during the initial stages of atherosclerosis may accelerate the process while infections may have no effect on lesion progression when the plaques are already in a more advanced stage.

Whereas Cpn had no effect on total lesion size or lesion type, the percentage occupied by the fibrous cap was significantly reduced in Cpn-infected animals. At the same time, the fraction of the plaque occupied by the lipid core was significantly increased in Cpn infected mice when compared to control animals. As a thin fibrous cap and a large lipid core are the main characteristics of plaques vulnerable to rupture ${ }^{34}$ these findings suggest that $\mathrm{Cpn}$ infections induce an unstable plaque phenotype. As plaque destabilisation may result in plaque rupture, thrombosis and acute clinical syndromes such as acute coronary syndromes and myocardial infarction, we infected or mock injected mice and waited until sudden death occurred. In line with our expectation, sudden death took place at much earlier time points in infected mice. Furthermore, at (post mortem) autopsy we indeed found signs of plaque rupture and (healed) myocardial infarcts in both groups. Taken together these findings suggest that Cpn infections induce an unstable plaque phenotype, thereby increasing the risk for future cardiovascular complications, such as plaque rupture and subsequent myocardial infarction or stroke.

MMPs are a family of enzymes that selectively digest individual components of the extracellular matrix, thereby playing an important role in maintaining the vessels integrity. ${ }^{35}$ However, in certain environments these MMPs may contribute to pathologies such as restenosis, ${ }^{36}$ to the de novo formation of atherosclerotic plaques ${ }^{37}$ or to plaque rupture of by degrading the fibrous cap that surrounds them. ${ }^{38}$ Interestingly, it has recently been demonstrated that $\mathrm{Cpn}$ is able to stimulate the production of MMP2 and -9 by macrophages ${ }^{8}$. Furthermore, immunoreactivity for MMP-2 and MMP-9 were found to be increased in human atheromatous plaques, and predominantly in immunoreactive macrophages/mononuclear cells to $\mathrm{Cpn} .{ }^{39}$ Also, zymographic analysis revealed that activities of MMP-2 and MMP-9 were more increased in atherosclerotic tissues infected with Cpn compared to control tissues. ${ }^{10,11}$ Based on these findings we conjectured a role for these MMPs in the observed plaque destabilisation following Cpn infection. Various techniques were used to verify this hypothesis. Although a marked up-regulation of both MMP antigens in the lesions was observed, activity, measured by zymography or mRNA expression levels were similar in both groups. This suggests that a role for these specific MMPs is less likely which is in accordance with data from others. Rodel and co-workers demonstrated a lack of effect of $\mathrm{Cpn}$ 
infection on MMP-2 and -9 mRNA levels in smooth muscle cells. ${ }^{9}$ Also, no association between the presence of Cpn DNA and increased activity of MMP-2 and -9 could be demonstrated in aneurysmatic abdominal aortas, ${ }^{40}$ indicating a minor role for these specific MMPs in murine plaque destabilisation following Cpn infection. Nevertheless, in the mean time other corrosive enzymes, such as collagenases (MMP-1 and -8) and stromelysins (MMP-3), have been associated with Cpn infection and should be subject for further study. Furthermore, a limitation of the present study is that the activity of tissue inhibitors of the MMPs (TIMPs) was not investigated. Increased activity of these TIMPs may result in a failure to disclose an increased MMP activity in the vascular tissue. Another interesting topic for future study is MMP-2 and -9 expression at protein level by western blot. However, to study TIMPs activity and MMP-2 and -9 protein expression a new group of atherosclerotic aortic arches from ApoE-/-LDLr-/- mice are needed.

In conclusion, our results suggest that $\mathrm{Cpn}$ infection does not aggravate the atherosclerotic process in ApoE-/-LDLr-/- mice by increasing the size of the lesions but initiates a cascade of events, ultimately resulting in thinning of the fibrous cap and an increase of the necrotic core, both indicative of an unstable plaque phenotype. When mice were observed for a longer time period a reduction in survival occurred in the Cpn-infected mice due to cardiovascular complications. To our knowledge, this is the first study to demonstrate an in vivo mechanism that may account for the increased incidence of myocardial infarction among Cpn positive coronary heart disease other then the initially suggested aggravation of atherosclerotic plaque formation. 


\section{References}

1. Saikku P, Leinonen M, Mattila K, Ekman MR, Nieminen MS, Makela PH, Huttunen JK, Valtonen V. Serological evidence of an association of a novel Chlamydia, TWAR, with chronic coronary heart disease and acute myocardial infarction. Lancet. 1988;2:983-6.

2. Gupta S, Leatham EW, Carrington D, Mendall MA, Kaski JC, Camm AJ. Elevated Chlamydia pneumoniae antibodies, cardiovascular events, and azithromycin in male survivors of myocardial infarction. Circulation. 1997;96:404-7.

3. Hu H, Pierce GN, Zhong G. The atherogenic effects of chlamydia are dependent on serum cholesterol and specific to Chlamydia pneumoniae. J Clin Invest. 1999;103:747-53.

4. Liu L, Hu H, Ji H, Murdin AD, Pierce GN, Zhong G. Chlamydia pneumoniae infection significantly exacerbates aortic atherosclerosis in an LDLR-/- mouse model within six months. Mol Cell Biochem. 2000;215:123-8.

5. Gaydos CA, Summersgil J, Sahney N, Ramirez J, Quinn TC. Replication of Chlamydia pneumoniae in vitro in human macrophages, endothelial cells and aortic artery smooth muscle cells. Infect Immun. 2001;69:1420-1427.

6. Kalayoglu M, Byrne GI. Induction of macrophage foam cell formation by Chlamydia pneumoniae. J. Infect. Dis. 1998;177:725-729.

7. Ezzahiri R, Nelissen-Vrancken H, Kurvers H, Stassen F, Vliegen I, Grauls G, van Pul M, Kitslaar P, Bruggeman C. Chlamydophila pneumoniae (Chlamydia pneumoniae) accelerates formation of complex atherosclerotic lesion in Apo E3-Leiden mice. Cardiovascular Research. 2002;56:269-76.

8. Kol A, Sukhova GK, Lichtman AH, Libby P. Chlamydial heat shock protein 60 localizes in human atheroma and regulates macrophage tumor necrosis factor-alpha and matrix metalloproteinase expression. Circulation. 1998;98:300-7.

9. Rodel J, Prochnau D, Prager K, Pentcheva E, Hartmann M, Straube E. Increased production of matrix metalloproteinases 1 and 3 by smooth muscle cells upon infection with Chlamydia pneumoniae. FEMS Immunol Med Microbiol. 2003;38:159-64.

10. Choi EY, Kim D, Hong BK, Kwon HM, Song YG, Byun KH, Park HY, Whang KC, Kim HS. Upregulation of extracellular matrix metalloproteinase inducer (EMMPRIN) and gelatinases in human atherosclerosis infected with Chlamydia pneumoniae: The potential role of Chlamydia pneumoniae infection in the progression of atherosclerosis. Exp Mol Med. 2002;34:391-400.

11. Song YG, Kwon HM, Kim JM, Hong BK, Kim DS, Huh AJ, Chang KH, Kim HY, Kang TS, Lee BK, Choi DH, Jang YS, Kim HS. Serologic and histopathologic study of Chlamydia pneumoniae infection in atherosclerosis: a possible pathogenetic mechanism of atherosclerosis induced by Chlamydia pneumoniae. Yonsei Med J. 2000;41:319-27.

12. Roblin PM, Dumornay W, Hammerschlag MR. Use of HEp-2 cells for improved isolation and passage of Chlamydia pneumoniae. J Clin Microbiol. 1992;30:1968-71.

13. Vainas T, De Graaf R, Stassen FR, Kurvers HA, Grauls GE, Kitslaar PJ, Bruggeman CA. Chlamydia pneumoniae serology: comparing a commercial enzyme immunoassay and microimmunofluorescence test in patients with cardiovascular disease. Apmis. 2003;111:363-9.

14. Tong CY, Sillis M. Detection of Chlamydia pneumoniae and Chlamydia psittaci in sputum samples by PCR. J Clin Pathol. 1993;46:313-7.

15. Lutgens E, Daemen M, Kockx M, Doevendans P, Hofker M, Havekes L, Wellens H, de Muinck ED. Atherosclerosis in APOE*3-Leiden transgenic mice: from proliferative to atheromatous stage. Circulation. 1999;99:276-83. 
16. Ezzahiri R, Stassen F, Kurvers H, van Pul M, Kitslaar P, Bruggeman C. Chlamydia pneumoniae infection induces an unstable atherosclerotic plaque phenotype in LDL-receptor, ApoE double knockout mice. European Journal of Vascular and Endovascular Surgery. 2003;26:88-95.

17. Stary HC, Chandler AB, Dinsmore RE, Fuster V, Glagov S, Insull W, Jr., Rosenfeld ME, Schwartz CJ, Wagner WD, Wissler RW. A definition of advanced types of atherosclerotic lesions and a histological classification of atherosclerosis. A report from the Committee on Vascular Lesions of the Council on Arteriosclerosis, American Heart Association. Arterioscler Thromb Vasc Biol. 1995;15:1512-31.

18. Aikawa M, Rabkin E, Okada Y, Voglic SJ, Clinton SK, Brinckerhoff CE, Sukhova GK, Libby $\mathrm{P}$. Lipid lowering by diet reduces matrix metalloproteinase activity and increases collagen content of rabbit atheroma: a potential mechanism of lesion stabilization. Circulation. 1998;97:2433-44.

19. Rekhter MD, Hicks GW, Brammer DW, Hallak H, Kindt E, Chen J, Rosebury WS, Anderson MK, Kuipers PJ, Ryan MJ. Hypercholesterolemia causes mechanical weakening of rabbit atheroma : local collagen loss as a prerequisite of plaque rupture. Circ Res. 2000;86:101-8.

20. Bancroft J, Stevens A. Theory and practice of histological techniques. In. 2nd edition ed. Edinburgh: Churchil Livingstone; 1982:32.

21. Nicholls JM. Rapid method for fetal brain fixation. J Clin Pathol. 1988;41:1019-20.

22. Smith AA. Specific staining of tissue components with metal-hematoxylin complexes. Micron. 2002;33:95-103.

23. Cleutjens JP, Kandala JC, Guarda E, Guntaka RV, Weber KT. Regulation of collagen degradation in the rat myocardium after infarction. J Mol Cell Cardiol. 1995;27:1281-92.

24. Silence J, Collen D, Lijnen HR. Reduced atherosclerotic plaque but enhanced aneurysm formation in mice with inactivation of the tissue inhibitor of metalloproteinase-1 (TIMP-1) gene. Circ Res. 2002;90:897-903.

25. Mahony JB, Coombes BK. Chlamydia pneumoniae and atherosclerosis: does the evidence support a causal or contributory role? FEMS Microbiol Lett. 2001;197:1-9.

26. Moazed TC, Campbell LA, Rosenfeld ME, Grayston JT, Kuo CC. Chlamydia pneumoniae infection accelerates the progression of atherosclerosis in apolipoprotein E-deficient mice. J Infect Dis. 1999;180:238-41.

27. Gaydos CA, Summersgill JT, Sahney NN, Ramirez JA, Quinn TC. Replication of Chlamydia pneumoniae in vitro in human macrophages, endothelial cells, and aortic artery smooth muscle cells. Infect Immun. 1996;64:1614-20.

28. Kaukoranta-Tolvanen SS, Laitinen K, Saikku P, Leinonen M. Chlamydia pneumoniae multiplies in human endothelial cells in virto. Microb Pathog. 1994;16:313-319.

29. Kol A, Libby P. The mechanisms by which infectious agents may contribute to atherosclerosis and its clinical manifestations. Trends Cardiovasc Med. 1998;8:191-199.

30. Molestina R, Miller R, Ramirez J, Summersgil J. Infection of human endothelial cells with Chlamydia pneumoniae stimulates transendothelial migration of neutrophils and monocytes. Infect. Immun. 1999;67:1323-1330.

31. Gaydos CA. Growth in vascular cells and cytokine production by Chlamydia pneumoniae. J. Infect. Dis. 2000;181:S473-S478.

32. Rothstein NM, Quinn TC, Madico G, Gaydos CA, Lowenstein CJ. Effect of azithromycin on murine arteriosclerosis exacerbated by Chlamydia pneumoniae. J Infect Dis. 2001;183:232-238.

33. Moazed TC, Kuo CC, Grayston JT, Campbell LA. Evidence of systemic dissemination of Chlamydia pneumoniae via macrophages in the mouse. J Infect Dis. 1998;177:1322-5. 
34. Libby P. Changing concepts of atherogenisis. J. Inter. Med. 2000;247:349-358.

35. Shah PK, Galis ZS. Matrix metalloproteinase hypothesis of plaque rupture: players keep piling up but questions remain. Circulation. 2001;104:1878-80.

36. Kuzuya M, Kanda S, Sasaki T, Tamaya-Mori N, Cheng X, Itoh T, Itohara S, Iguchi A. Deficiency of gelatinase A suppresses smooth muscle cell invasion development of experimental intimal hyperplasia. Circulation. 2003;108:1375-1381.

37. Lindtstedt L, Saarinen J, Kalkkinen N, Welgus H, Kovanen P. Matrix metalloproteinases-3, -7 , and -12 , but not -9 , reduce high density lipoprotein-induced cholesterol efflux from human macrophage foam cells by truncation of the carboxyl terminus of Apolipoprotein AI. J Biol Chem. 1999;274:22627-34.

38. Galis ZS, Sukhova GK, Kranzhofer R, Clark S, Libby P. Macrophage foam cells from experimental atheroma constitutively produce matrix-degrading proteinases. Proc Natl Acad Sci U S A. 1995;92:402-6.

39. Galis Z, Sukhova G, Lark M, Libby P. Increased expression of matrix metalloproteinases and matrix degrading activity in vulnerable regions of human atherosclerotic plaques. $J$ Clin Invest. 1994;94:2493-2503.

40. Petersen E, Boman J, Wagberg F, Angquist KA. Presence of Chlamydia pneumoniae in abdominal aortic aneurysms is not associated with increased activity of matrix metalloproteinases. Eur J Vasc Endovasc Surg. 2002;24:365-9. 


\section{CHAPTER 6}

\section{Anti-Chlamydia pneumoniae and anti-inflammatory properties of azithromycin in atherosclerotic mice}

Rajaa Ezzahiri, ${ }^{1}$ Frank RM Stassen, ${ }^{2}$ Harrie AJM Kurvers, ${ }^{1}$ Peter JEHM Kitslaar, ${ }^{1}$ Cathrien A Bruggeman. ${ }^{2}$

Department of Surgery, ${ }^{1}$ and Medical Microbiology, ${ }^{2}$ University Hospital Maastricht, the Netherlands. 


\begin{abstract}
Objective: Since Chlamydia pneumoniae (Cpn) infections have been linked with atherosclerosis, we decided to study the effect of antibiotic therapy on lesion development in mice.

Methods: ApoE-/-LDLr-/- mice were infected twice (at 16 \& 18 weeks) with Cpn or mock and treated with azithromycin $(10 \mathrm{mg} / \mathrm{kg} / \mathrm{day}, \mathrm{sc})$ or sterile PBS. Mice were then sacrificed at 20 weeks of age and aortic arch sections were analyzed for Cpn DNA, lesion type, lesion area, fibrous cap area, necrotic core content, T-cells, and matrix metalloproteinases (MMP)-2 and -9 .

Results: All mice developed atherosclerotic lesions (type 2 to 5b). Treatment of Cpninfected mice with azithromycin resulted in formation of less complex atherosclerotic lesions, decreased lesion area, lipid core area, T-cells, and MMP-2. Fibrous cap area was increased after azithromycin treatment. Intriguingly, also non-infected control mice treated with azithromycin showed less complex lesions and a significant reduction in lesion area and necrotic core area. In Cpn-infected mice treated with azithromycin 57\% (4/7) of vascular tissue samples remained Cpn DNA positive.

Conclusions: Here we demonstrate that azithromycin therapy not only prevents development of vulnerable plaques in Cpn-infected ApoE-/-LDLr-/- mice, but also in mockinfected mice. These data suggest that azithromycin has not only antibiotic properties but also anti-inflammatory.
\end{abstract}




\section{Introduction}

Although significant progress has been made in revealing important aspects in the etiology of atherosclerosis, the exact pathogenesis is not completely understood yet and the search for additional risk factors is ongoing.

One of the key events in lesion progression is inflammation of the vascular wall with subsequent activation of adhesion molecules, ${ }^{1}$ recruitment of monocytes, T-cells, and release of cytokines (IL-2, IFN $\gamma)^{2}$ leading to recruitment of more inflammatory cells and ultimately the development of atherosclerotic lesions. Increase of the inflammatory process has been suggested to stimulate and sustain the inflammation leading to unstable plaque morphology. Lately, infections in particular with Chlamydia pneumoniae (Cpn) have been reported to act as moderators of atherosclerosis in several seroepidemiological studies, ${ }^{3}$ animal studies, ${ }^{4}$ and in vitro experiments. ${ }^{5}$ We have demonstrated in an animal model that Cpn infection 1) augment the inflammatory process by increasing the number of T-lymphocytes in the plaque and 2) accelerating the formation of complex lesions. ${ }^{6}$ Also, 3) Cpn infection might alter the plaque phenotype from stable to vulnerable ${ }^{7}$ which may explain the correlation between myocardial infarction and Cpn. ${ }^{8}$

Since several lines of evidence have linked Cpn infection with progression of atherosclerotic disease, the question was raised whether antibiotic therapy would be an option to prevent or stabilize of the atherosclerotic process. ${ }^{9}$ To define the duration and quantity of antibiotic treatment several animal models, mice ${ }^{10}$ and rabbits ${ }^{11}$, were used. Treatment with azithromycin ${ }^{12}$ or clarithromycin ${ }^{11}$ resulted in reduction of atherosclerotic lesion size. Nonetheless, the effect of treatment on plaque morphology has not been documented yet. Therefore, we infected ApolipoproteinE, low density lipoprotein receptor double knockout (ApoE-/-LDLr-/-) mice ${ }^{13}$ with Cpn or control and used azithromycin or sham therapy to study the effect of antibiotic treatment on atherosclerotic plaque morphology.

\section{Methods}

Mice

Thirty-two male specific pathogen free (SPF) ApoE-/-LDLr-/- mice on a C57BI/6J background were used. Mice were housed under standard conditions at the Central Animal Facility of the Maastricht University and fed a normal chow diet (Hopefarms BV, Woerden, The Netherlands) and water ad libitum. All experiments were performed according to the institutional guidelines of the committee for the welfare of laboratory animals of the Maastricht University.

Chlamydia pneumoniae

Cpn strain TWAR 2043 (ATCC VR-1355) was cultured in Hep-2 cells as described previously. ${ }^{14}$ Bacterial titers were determined by titration in Hep-2 cells and stained with 
fluorescein-isothiocyanate-conjugated (FITC) monoclonal antibody RR 402 (Dako, Glostrup, Denmark) directed against a protein component of the cell membrane of Cpn. Titers were expressed as number of inclusion forming units per milliliter (IFU/ml).

\section{Study design}

In humans, multiple Cpn infections occur throughout one's lifetime. To mimic this situation, mice were reinfected two weeks after the first infection and were treated with azithromycin (an antibiotic used as therapy for Gram negative bacterial infections, gift from Pfizer Research Laboratories, Groton, Conn., United States) or sham treatment, which consisted of phosphate-buffered saline (PBS).

As described previously, ${ }^{7}$ animals were infected 2 times with Cpn starting at the age of 16 weeks via intraperitoneal (ip) injection of Cpn (5.106 IFU) while control mice (mock) received sucrose-phosphate-glucose (SPG) solution only. Previously we demonstrated that the dissemination process following ip injections is similar to the process following intranasal inoculations, but there is better control over the amount of $\mathrm{Cpn}$ that is applied to the animal (unpublished data). All mice received a second inoculation (5.106 IFU Cpn or mock) at the age of 18 weeks and were afterwards treated with azithromycin ( $n=7$ Cpn, $n=8$ mock) or sham therapy (PBS, $n=8$ Cpn, $n=8$ mock). Azithromycin therapy consisted of 7 consecutive subcutaneous (sc) injections of azithromycin $(10 \mathrm{mg} / \mathrm{kg}$ ), once a day, (figure 1). This dosage of azithromycin was chosen because it is known to give similar concentrations alike those achieved in humans after an oral dose of $500 \mathrm{mg}$ a day. ${ }^{15}$ Sham therapy was started 1 day after infection and was administrated sc once a day for 7 consecutive days from week 1617 and from week 18-19, (figure 1). All mice were sacrificed at the age of 20 weeks.

To determine the preferred way of administration of azithromycin in mice, a pilot study was performed before starting the present study. For this study, C57Black/6J mice were treated with azithromycin through sc administration once a day ${ }^{16}$ or orally via azithromycin in drinking water ad libitum. Plasma, lung and vascular tree were collected for determination of azithromycin concentrations by an Iso-sensitest agar (Oxoid Itd Pasingstoke, Hampshire, UK) with Micrococcus luteus ATCC 9341 as the testorganism. Subcutaneous administration of azithromycin resulted in higher tissue levels than oral therapy (data not shown). Therefore, in the present study mice were treated with azithromycin or PBS through sc administration.

\footnotetext{
Statistical analysis

Difference in lesion size, fibrous cap area, T-cell number, lipid core area and MMP-2 and -9 immunoreactivity between the $\mathrm{Cpn}$-infected and control mice treated with azithromycin or sham therapy were analyzed with the Mann-Whitney-U test. The same test was used to analyze differences in Cpn DNA of Cpn-infected mice that received sham therapy or azithromycin. Difference in lesion type between the Cpn-infected and control mice treated with azithromycin or sham therapy were analyzed with the Chisquare test. A p-value of $<0.05$ was considered statistically significant. Results are expressed as mean \pm SEM.
} 
Figure 1. Infection and treatment schedule for ApoE-/-LDLr-/- mice. Mice were infected with Cpn or mock at the age of 16 and 18 weeks. Treatment started 1 day after infection and consisted of $10 \mathrm{mg} / \mathrm{kg}$ azithromycin or sham (PBS) therapy sc, once a day, for 7 consecutive days from week 16-17 and week 18-19. All mice were sacrificed at the age of 20 weeks.

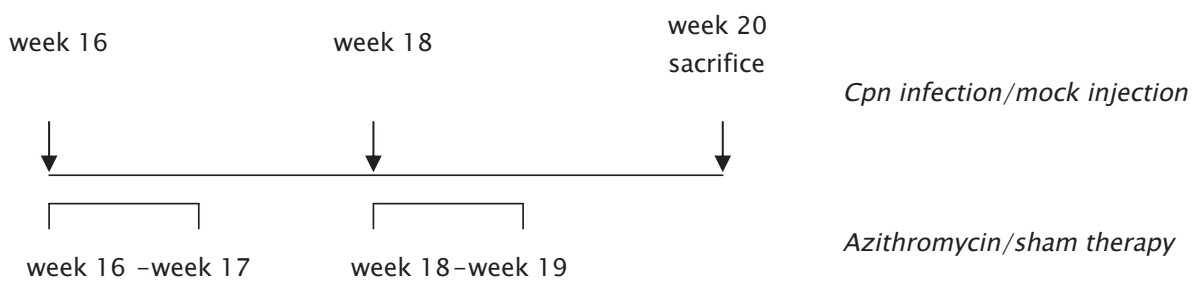

\section{Results}

Of the 32 mice used in the study, 1 mouse in group B (Cpn-infected and treated with azithromycin) died before reaching the time point of sacrifice. This mouse was excluded from the study, the cause of death remained unknown.

\section{Presence of anti-Cpn antibodies and Cpn DNA}

All Cpn-infected mice treated with either azithromycin or sham therapy developed antibodies at dilutions of 1:10 and 1:100, indicating that they had been infected successfully. Mock-infected mice treated with either azithromycin or sham therapy did not develop anti-Cpn antibodies.

Cpn DNA was detected in all aortic arches from Cpn-infected mice that received sham therapy, showing that intraperitoneal injection resulted in dissemination of $\mathrm{Cpn}$ to the vessel wall. In Cpn-infected mice on azithromycin therapy, 57\% (4/7 vs. 8/8 in the sham treated mice, $\mathrm{p}=0.03$ ) of all vascular tissue samples were positive for $\mathrm{Cpn}$ DNA, which demonstrates that antibiotic therapy does not completely eradicate Cpn from the vascular wall.

No positive results were observed in control-injected mice treated with azithromycin or sham.

Effect of antibiotic therapy on Cpn induced plaque progression and destabilisation ApoE-/-LDLr-/- mice were infected and lesion characteristics were determined 2 weeks after the last inoculation. Aortic arches of all mice contained atherosclerotic lesions ranging from type 2 to $5 \mathrm{~b}$. No effect of $\mathrm{Cpn}$ on the frequency of initial or advanced lesion (figure 2A) nor on lesion size (figure 2B) was observed. Yet, azithromycin treatment led to a significant reduction in lesion size. The average lesion area for sham treated was: $0.24 \pm 0.03 \mathrm{~mm}^{2}$ vs. $0.05 \pm 0.01 \mathrm{~mm}^{2}$ for azithromycin treatment (figure $2 \mathrm{~B}, \mathrm{p}<0.001$ ). Also, the frequency of advanced lesions was signifi- 
cantly reduced following azithromycin treatment $(\mathrm{p}=0.02$, figure $2 \mathrm{~A})$. Remarkably however, similar effects of azithromycin were observed in non-infected mice (sham therapy: $0.22 \pm 0.03 \mathrm{~mm}^{2}$ vs. azithromycin therapy: $0.07 \pm 0.01 \mathrm{~mm}^{2}, p<0.001$, figure $2 \mathrm{~B}$ ), suggesting a non-Cpn related effect of azithromycin on lesion development.

A significant increase was observed in the necrotic core of the lesions following Cpn infection, (mock: $0.12 \pm 0.02$ vs. Cpn: $0.24 \pm 0.03, p<0.001$, figure $2 \mathrm{C}$ ). Like for lesion size and frequency, azithromycin treatment also reduced the necrotic core content in both the Cpn infected group (sham: $0.24 \pm 0.03$ vs. azithromycin: $0.13 \pm 0.03, p=0.03$, figure $2 \mathrm{C}$ ) as well as in the mock group (sham: $0.12 \pm 0.02$ vs. azithromycin: $0.08 \pm$ $0.01, p=0.01$, figure $2 \mathrm{C}$ ).

Cpn infection significantly reduced the fibrous cap area, expressed as the fractional volume of the whole lesion (mock: $0.29 \pm 0.03$ vs. Cpn: $0.09 \pm 0.01, p<0.001$, figure 2D), providing further evidence for Cpn induced plaque destabilisation. Azithromycin treatment, however, completely prevented the reduction of the fibrous cap area, (sham: $0.09 \pm 0.01$ vs. azithromycin: $0.33 \pm 0.02, p<0.001$ ). In this case no effects of treatment were observed in the mock group (figure 2D).

Positive immunostaining for MMP-2 and -9 was mainly concentrated in the endothelial layer, the lipid core and the shoulder region of the lesions. Cpn infection resulted in a significant increase in MMP-2 positive staining (Cpn: $1.50 \pm 0.24$ vs mock: 0.83 $0.18, \mathrm{p}<0.05)$. Treatment with azithromycin resulted in a significant reduction in MMP2 positive staining (sham: $1.50 \pm 0.24$ vs. azithromycin: $0.86 \pm 0.15, p<0.05$ ). No significant effects of azithromycin on MMP-2 immunoreactivity were observed in the mock-infected group (sham: $0.83 \pm 0.18$ vs. azithromycin: $0.75 \pm 0.27$, ns).

A significant increase in MMP-9 immunoreactivity was observed in lesions following Cpn infection (mock: $0.25 \pm 0.17$ vs. Cpn: $0.75 \pm 0.17, p<0.05$ ). And although a slight reduction in MMP-9 immunoreativity was observed in either the Cpn-infected group (sham: $0.75 \pm 0.17$ vs. azithromycin: $0.43 \pm 0.22$ ) or the mock-injected group (sham: $0.25 \pm 0.17$ vs. azithromycin: 0.330 .41 ) following azithromycin treatment, differences never reached the level of statistical significance.

In Cpn-infected mice, azithromycin therapy resulted in a significant decrease in $\mathrm{T}$ cell influx from 0.36.10-4 $\pm 0.59 .10-5$ cells/lesion area following sham therapy to 0.79.10-5 $\pm 0.35 .10-5$ cells/lesion area following azithromycin treatment, $p<0.001$, figure $2 \mathrm{E}$. Also, in the mock-infected mice a slight reduction in T-cells after azithromycin therapy was observed from $0.31 .10-4 \pm 0.15 .10-4$ cells/lesion area in the sham treated group to $0.23 .10-4 \pm 0.06 .10-4$ cells/lesion area in the azithromycin group. This difference was not statistically significant, (figure $2 \mathrm{E}$ ). 
Figure 2. The effect of azithromycin therapy on atherosclerotic plaque phenotype of ApoE-/-LDLr-/- mice infected with Cpn or control. A. Lesion types presented as the mean frequency \pm SEM at which that type of lesion was present. No effect of Cpn on the frequency of initial or advanced lesion was observed. The frequency of advanced lesions was significantly reduced following azithromycin treatment in the Cpn-infected and mock-infected mice. B. Lesion area was expressed as mean lesion area (mm2) of all plaques measured. No effect of Cpn on lesion area was observed. Lesion area was significantly reduced following azithromycin treatment in the Cpn-infected and mock-infected mice. C. Lipid core area was expressed as the fractional volume of the whole lesion occupied by each of them. D. Fibrous cap was expressed as the fractional volume of the whole lesion occupied by each of them. E. T cell content of the lesion was expressed as the number of $T$ cells in the plaque divided by total lesion area.
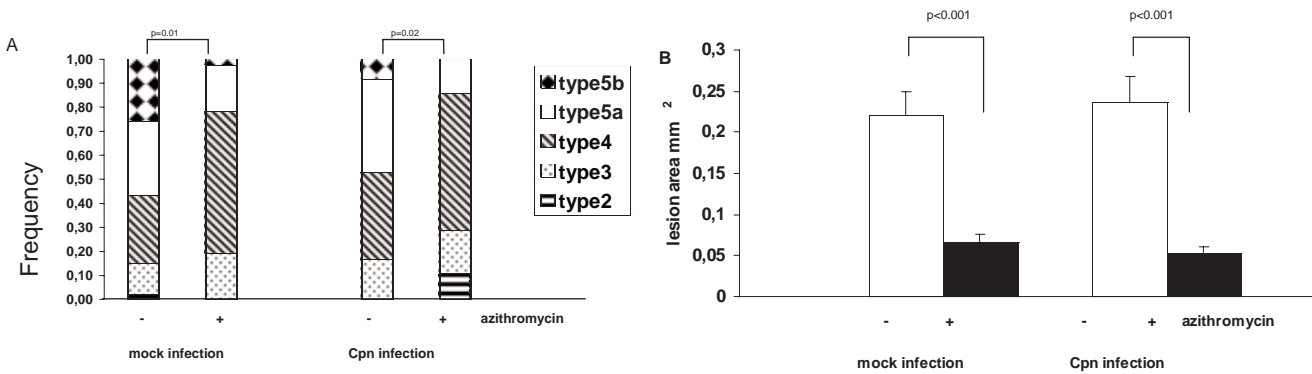

C

D
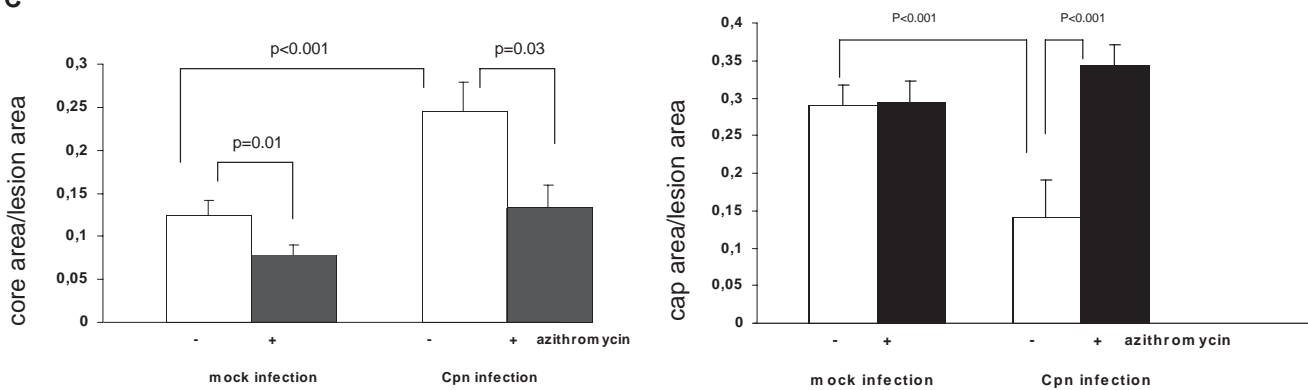

E

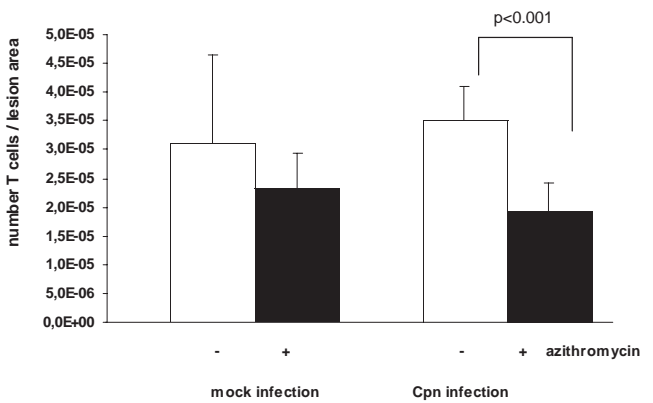




\section{Discussion}

The association between $\mathrm{Cpn}$ infections and atherosclerotic lesion progression has been demonstrated in sero-epidemiological studies, ${ }^{3}$ animal models ${ }^{4}$ and in vitro studies showing presence of $\mathrm{Cpn}$ antigen, $\mathrm{DNA}^{17}$ and viable $\mathrm{Cpn}^{18}$ in atherosclerotic lesions. Potential mechanisms by which $\mathrm{Cpn}$ infection affects the atherosclerotic process, such as upregulation of adhesion molecules and continuous release of inflammatory mediators, have been reported..$^{19}$

$W^{6}{ }^{6}$ and others ${ }^{20,21}$ have demonstrated that $\mathrm{Cpn}$ infection enhances the inflammatory process by increasing T-cell influx in the plaque and accelerating the formation of complex lesions. Moreover, plaque phenotype is shifted from stable to vulnerable plaque after multiple Cpn infections. ${ }^{7}$ However, in the present study, lesion area, lesion type and influx of T-cells of 20 week-old ApoE-/-LDLr-/- mice were not affected by infection with Cpn. In contrast, other studies, ${ }^{10}$ in which mice were infected at a younger age, demonstrated an increase in lesion area. Our mice were infected at 16 weeks, at which time point advanced lesion types are predominantly present. This suggests that $\mathrm{Cpn}$ infection in the presence of early atherosclerotic lesions results in modification of lesion type, lesion area and T-cell influx, whereas infection of mice with advanced lesions, as in the present study, did not result in these changes (figure $2 \mathrm{~A}$, $B, E$ ). This explains the results of the present study where lesion area, size and T cell influx were, in contrast with other studies, not affected after Cpn infection.

For determination of atherosclerotic plaque morphology, not only lesion type, lesion area and T-cell influx are important, but more precise markers, as fibrous cap area and necrotic/lipid core area, must be included. The latter markers can be used to distinguish between stable and unstable lesions and define plaque phenotype. The present study shows that the necrotic core was increased and the fibrous cap area decreased following Cpn infection. Furthermore, MMP-2 and -9 immunoreactivity in the plaque were increased following infection suggesting a role for extracellular matrix degradation. Thus, Cpn infection modifies several markers of plaque stability, MMP-2 and -9 , fibrous cap and necrotic core area, inducing the formation of a more unstable, and consequently more rupture prone plaque phenotype.

Since we are convinced that this is an important observation we posed the question as to whether Cpn eradication through antibiotic therapy will ameliorate the course of the atherosclerotic process. In the present study, we demonstrated that in Cpn-infected mice azithromycin therapy resulted in the formation of less complex atherosclerotic lesions, reduction in lesion and lipid core area and also reduction in T cell influx and presence of MMP-2 and prevented reduction of cap area. Although other animal studies reported a reduction in lesion area after azithromycin ${ }^{22}$ or clarithromycin ${ }^{11}$ therapy, reports concerning the effect of treatment on atherosclerotic plaque phenotype are lacking. Thus, the results of the present study corroborate the role of $\mathrm{Cpn}$ in atherosclerotic lesion progression and the effect of azithromycin on this process.

The anti-Cpn effect of azithromycin has been confirmed in several other animal models. Muhlestein and coworkers infected New Zealand White rabbits on an athero- 
genic diet with Cpn or saline at 3 weeks intervals and treated them with azithromycin or no therapy for 7 weeks. ${ }^{12}$ Plaque area in the thoracic aorta was increased in the infected rabbits compared to both uninfected controls and infected rabbits receiving antibiotics. Using clarithromycin therapy after 3 Cpn infections (2 weeks apart) in rabbits, Fong and coworkers found a reduction in the number of lesions and in Cpn antigen content in the vascular tree. ${ }^{11}$ Earlier studies performed by the same group, ${ }^{23}$ reported similar results although azithromycin was used instead of clarithromycin with shorter treatment protocols. ${ }^{22}$

These observations are in line with early small secondary prevention trials in patients, ${ }^{3,24}$ which showed a significant reduction in cardiovascular events (death, myocardial infarction or admission for unstable angina). However, results of clinical trials with larger patient numbers were less positive for patient mortality and morbidity. ${ }^{25}$ For explanation of these contrasting findings, several implications and limitations of antibiotic trials should be taken into consideration. Not only incorrect hypothesis but also inadequate study size or design may explain negative outcomes of antibiotic trials. ${ }^{26}$ Furthermore, effective eradication of $\mathrm{Cpn}$ by antibiotics is difficult or even impossible, since this pathogen enters a persistent state not refractory to antibiotic treatment. This has been demonstrated in Cpn-infected circulating human monocytes, which were treated with azithromycin in vitro and in vivo without achieving eradication of Cpn. ${ }^{27}$ Kutlin and coworkers used continuously infected HEp-2 cells that were treated for 30 days with azithromycin, clarithromycin, or levofloxacin and found no elimination of $\mathrm{Cpn}{ }^{28}$ Also, results from our study show that azithromycin therapy does not eradicate $\mathrm{Cpn}$ from the vascular wall since 4 out of $7 \mathrm{Cpn}$-infected mice remained $\mathrm{Cpn}$ DNA positive after azithromycin treatment.

Several animal studies ${ }^{10,29}$ demonstrated that antibiotic treatment beginning early after infection was more effective than delayed treatment. Our study confirms these observations, since we started azithromycin therapy one day after infection and found an effect on atherosclerotic lesion progression. This suggests that eradication of $\mathrm{Cpn}$ with antibiotics can be achieved in active Cpn infections while persistent infections are difficult to eradicate.

Interestingly, azithromycin therapy in the present study not only affected plaque phenotype in Cpn-infected mice, but showed similar effects in atherosclerotic lesions of mock-infected mice. This suggests that besides the anti-Cpn effect, azithromycin has anti-inflammatory properties that affect atherosclerotic plaque phenotype in ApoE- $/$ LDLr-/- mice. These observations are confirmed by Hall and coworkers ${ }^{30}$ who demonstrated that stimulation of human monocytes and subsequent treatment with azithromycin in vitro resulted in reduction of TNF- $\alpha$ and IL-6. In contrast, a recent study in human hepatocytes did not display a direct anti-inflammatory effect of azithromycin. ${ }^{31}$ Besides in vitro evidence, azithromycin revealed anti-inflammatory capacities in vivo, as measured on the basis of reduced plasma concentrations of IL6 and CRP ${ }^{32}$ The ACADEMIC trial33 reported a significant reduction in global rank sum score of 4 inflammatory markers (CRP, IL-1, IL-6, and TNF- $\alpha$ ) after azithromycin therapy at 6 , but not at 3 months follow up. Other studies ${ }^{34,35}$ with small patient num- 


\section{References}

1. Hansson G. Immune mechanisms in atherorosclerosis. Arterioscler Thromb Vasc Biol. 2001;21:1897-90.

2. Frostegard J, Ulfgren AK, Nyberg P, Hedin U, Swedenborg J, Andersson U, Hansson GK. Cytokine expression in advanced human atherosclerotic plaques: dominance of pro-inflammatory (Th1) and macrophage-stimulating cytokines. Atherosclerosis. 1999;145:33-43.

3. Gupta S, Leatham EW, Carrington D, Mendall MA, Kaski JC, Camm AJ. Elevated Chlamydia pneumoniae antibodies, cardiovascular events, and azithromycin in male survivors of myocardial infarction. Circulation. 1997;96:404-7.

4. Hu H, Pierce GN, Zhong G. The atherogenic effects of chlamydia are dependent on serum cholesterol and specific to Chlamydia pneumoniae. J Clin Invest. 1999;103:747-53.

5. Coombes BK, Mahony JB. Chlamydia pneumoniae infection of human endothelial cells induces proliferation of smooth muscle cells via an endothelial cell-derived soluble factor(s). Infect Immun. 1999;67:2909-15.

6. Ezzahiri R, Nelissen-Vrancken H, Kurvers H, Stassen F, Vliegen I, Grauls G, van Pul M, Kitslaar P, Bruggeman C. Chlamydophila pneumoniae (Chlamydia pneumoniae) accelerates formation of complex atherosclerotic lesion in Apo E3-Leiden mice. Cardiovascular Research. 2002;56:269-76.

7. Ezzahiri R, Stassen F, Kurvers H, van Pul M, Kitslaar P, Bruggeman C. Chlamydia pneumoniae infection induces an unstable atherosclerotic plaque phenotype in LDL-receptor, ApoE double knockout mice. European Journal of Vascular and Endovascular Surgery. 2003;26:88-95.

8. Saikku P, Leinonen M, Mattila K, Ekman MR, Nieminen MS, Makela PH, Huttunen JK, Valtonen V. Serological evidence of an association of a novel Chlamydia, TWAR, with chronic coronary heart disease and acute myocardial infarction. Lancet. 1988;2:983-6.

9. Muhlestein JB. Antibiotic treatment of atherosclerosis. Curr Opin Lipidol. 2003;14:605-14.

10. Rothstein NM, Quinn TC, Madico G, Gaydos CA, Lowenstein CJ. Effect of azithromycin on murine arteriosclerosis exacerbated by Chlamydia pneumoniae. J Infect Dis. 2001;183:232-238.

11. Fong IW, Chiu B, Viira E, Jang D, Mahony JB. Influence of clarithromycin on early atherosclerotic lesions after Chlamydia pneumoniae infection in a rabbit model. Antimicrob Agents Chemother. 2002;46:2321-6.

12. Muhlestein JB, Anderson JL, Hammond EH, Zhao L, Trehan S, Schwobe EP, Carlquist JF. Infection with Chlamydia pneumoniae accelerates the development of atherosclerosis and treatment with azithromycin prevents it in a rabbit model. Circulation. 1998;97:633-6.

13. Ijiri $Y$, Miura M, Hashimoto M, Fukunaga C, Watanabe S, Kubota A, Oiwa K, Okuda T, Yamamoto J. A new model to evaluate the diet-induced prothrombotic state, using $\mathrm{He}-\mathrm{Ne}$ laser-induced thrombogenesis in the carotid artery of apolipoprotein E-deficient and lowdensity lipoprotein receptor-deficient mice. Blood Coagul Fibrinolysis. 2002;13:497-504.

14. Roblin PM, Dumornay W, Hammerschlag MR. Use of HEp-2 cells for improved isolation and passage of Chlamydia pneumoniae. J Clin Microbiol. 1992;30:1968-71.

15. Bin XX, Wolf K, Schaffner T, Malinverni R. Effect of azithromycin plus rifampin versus amoxicillin alone on eradication and inflammation in the chronic course of Chlamydia pneumoniae pneumonitis in mice. Antimicrob Agents Chemother. 2000;44:1761-4.

16. Degerli K, Kilimcioglu A, Kurt O, Tamay A, Ozbilgin A. Efficacy of azithromycin in a murine toxoplasmosis model, employing a Toxoplasma gondii strain from Turkey. Acta Tropica. 2003;88:45-50. 
17. Campbell LA, O'Brien ER, Cappuccio AL, Kuo CC, Wang SP, Stewart D, Patton DL, Cummings PK, Grayston JT. Detection of Chlamydia pneumoniae TWAR in human coronary atherectomy tissues. J Infect Dis. 1995;172:585-8.

18. Ramirez JA. Isolation of Chlamydia pneumoniae from the coronary artery of a patient with coronary atherosclerosis. The Chlamydia pneumoniae/Atherosclerosis Study Group. Ann Intern Med. 1996;125:979-82.

19. Coombes BK, Mahony JB. cDNA array analysis of altered gene expression in human endothelial cells in response to Chlamydia pneumoniae infection. Infect. Immun. 2001;69:1420-1427.

20. Mosorin M, Surcel HM, Laurila A, Lehtinen M, Karttunen R, Juvonen J, Paavonen J, Morrison RP, Saikku P, Juvonen T. Detection of Chlamydia pneumoniae-reactive T lymphocytes in human atherosclerotic plaques of carotid artery. Arterioscler Thromb Vasc Biol. 2000;20:1061-7.

21. Nadareishvili ZG, Koziol DE, Szekely B, Ruetzler C, LaBiche R, McCarron R, DeGraba TJ. Increased CD8(+) T Cells Associated With Chlamydia pneumoniae in Symptomatic Carotid Plaque. Stroke. 2001;32:1966-72.

22. Fong IW, Chiu B, Viira E, Jang D, Fong MW, Peeling R, Mahony JB. Can an antibiotic (macrolide) prevent Chlamydia pneumoniae-induced atherosclerosis in a rabbit model? Clin Diagn Lab Immunol. 1999;6:891-4.

23. Fong IW. Antibiotics effects in a rabbit model of Chlamydia pneumoniae-induced atherosclerosis. J Infect Dis. 2000;181 Suppl 3:S514-8.

24. Wiesli P, Czerwenka W, Meniconi A, Maly FE, Hoffmann U, Vetter W, Schulthess G. Roxithromycin treatment prevents progression of peripheral arterial occlusive disease in Chlamydia pneumoniae seropositive men: a randomized, double-blind, placebo-controlled trial. Circulation. 2002;105:2646-52.

25. Jackson LA. Description and status of the azithromycin and coronary events study (ACES). J Infect Dis. 2000;181 Suppl 3:S579-81.

26. Anderson J, Muhlestein J. Antibiotic trials for cornary heart disease. Tex Heart Inst $\mathrm{J}$. 2004;31:33-8.

27. Gieffers J, Fullgraf H, Jahn J, Klinger M, Dalhoff K, Katus HA, Solbach W, Maass M. Chlamydia pneumoniae infection in circulating human monocytes is refractory to antibiotic treatment. Circulation. 2001;103:351-6.

28. Kutlin A, Roblin PM, Hammerschlag MR. Effect of prolonged treatment with azithromycin, clarithromycin, or levofloxacin on Chlamydia pneumoniae in a continuous-infection Model. Antimicrob Agents Chemother. 2002;46:409-12.

29. Fong IW. Infections and their role in atherosclerotic vascular disease. J Am Dent Assoc. 2002;133 Suppl:7S-13S.

30. Hall IH, Schwab UE, Ward ES, Butts JD, Wolford ET, Ives TJ. Disposition and intracellular activity of azithromycin in human THP-1 acute monocytes. Int $\mathrm{J}$ Antimicrob Agents. 2002;20:348-60.

31. Bouwman J, Visseren FL, Bouter P, Diepersloot P. Azithromycin inhibits interleukin-6 but not fibrinogen production in hepatocytes infected with cytomegalovirus and Chlamydia pneumoniae. J Lab Clin Med. 2004;144:18-26.

32. Culic O, Erakovic V, Cepelak I, Barisic K, Brajsa K, Ferencic Z, Galovic R, Glojnaric I, Manojlovic Z, Munic V, Novak-Mircetic R, Pavicic-Beljak V, Sucic M, Veljaca M, ZanicGrubisic T, Parnham MJ. Azithromycin modulates neutrophil function and circulating inflammatory mediators in healthy human subjects. Eur J Pharmacol. 2002;450:277-289. 
33. Anderson JL, Muhlestein JB, Carlquist J, Allen A, Trehan S, Nielson C, Hall S, Brady J, Egger M, Horne B, Lim T. Randomized secondary prevention trial of azithromycin in patients with coronary artery disease and serological evidence for Chlamydia pneumoniae infection: The Azithromycin in Coronary Artery Disease: Elimination of Myocardial Infection with Chlamydia (ACADEMIC) study. Circulation. 1999;99:1540-7.

34. Hillis G, Pearson C, Harding S, Sutherland S, Ludlam C, Marioni C, Prescott R, Fox K, Flapan A. Effects of a brief course of azithromycin on soluble cell adhesion molecules and markers of inflammation in survivors of an acute coronary syndrome: A double blind, randomized, placebo-controlled study. Am Heart J. 2004;148:72-9.

35. Parchure N, Zouridakis EG, Kaski JC. Effect of azithromycin treatment on endothelial function in patients with coronary artery disease and evidence of Chlamydia pneumoniae infection. Circulation. 2002;105:1298-303.

36. Uriarte SM, Molestina RE, Miller RD, Bernabo J, Farinati A, Eiguchi K, Ramirez JA, Summersgill JT. Effect of macrolide antibiotics on human endothelial cells activated by Chlamydia pneumoniae infection and tumor necrosis factor-alpha. J Infect Dis. 2002;185:1631-6. 
CHAPTER 7

General Discussion 


\section{Introduction}

Although the first reports suggesting a possible role for infections in cardiovascular disease were published already at the beginning of the 20th century ${ }^{1,23}$ it took until the late 1970 's ${ }^{4}$ before the interest in infections as a potential risk factor for atherosclerosis was renewed. At that time, Julius and Catherine Fabricant ${ }^{5}$ demonstrated the prominent presence of atheroma in chickens infected with an avian herpes virus, suggesting a potential role for infections in the etiology of atherosclerosis. Yet, it was the seminal paper by Saikku and coworkers 5 that stimulated many researchers to study the role of the respiratory pathogen Chlamydia pneumoniae (Cpn) in the progression of atherosclerotic cardiovascular disease. Since then, numerous sero-epidemiological studies have reported an association of Cpn antibodies with myocardial infarction, chronic coronary heart disease $\mathrm{e}^{4}$ and an increased relative risk for cardiovascular complications. ${ }^{6}$ Furthermore, Cpn DNA ${ }^{7}$ as well as antigen ${ }^{7,8}$ and even viable $\mathrm{Cpn}^{7}$ has been detected in the atherosclerotic vascular tissue. Nevertheless, the majority of these studies were rather observational in nature and no clear molecular mechanisms by which Cpn might contribute to atherosclerosis were identified. Therefore, one of the main objectives of the present thesis was to elucidate potential mechanisms by which Cpn may aggravate atherosclerosis.

Atherosclerosis is a progressive disease that already starts at a rather young age and progresses with time. Initially, lesions are small and their organization is considerably different from advanced lesions, which can be found in the vascular tree at later age. As exposure to Cpn is extremely common, and respiratory infections occur repeatedly among most people it may be anticipated that Cpn can infect both early as well as advanced lesions. However, to our knowledge it has not been evaluated yet whether this affects lesions in a different way. Therefore we studied the effect of Cpn infection on lesion size and composition either in young mice with early lesion only, or in aged mice with severe atherosclerosis. Also, we evaluated the effect of frequent infection on lesion development, either in normal mice (Chapter 4) or in atherosclerotic mice (Chapter 3,5) Finally, we determined whether the effect of Cpn on atherosclerosis can be prevented by antibiotic treatment (Chapter 6).

Dissemination of Cpn in mouse model Although Cpn has recently been associated with extrapulmonary diseases like Alzheimer's disease, ${ }^{9}$ multiple sclerosis, ${ }^{10}$ reactive arthritis ${ }^{11}$ and atherosclerosis, ${ }^{4}$ it is an obligatory intracellular pathogen, which predominantly causes respiratory infections such as pneumonia, bronchitis and pharyngitis. ${ }^{12}$ As its natural route of infection is through the airways, it might be obvious to infect (atherosclerotic) mice intranasally by droplets administered onto the nostrils when you want to study the effect of infection on vascular pathology. Nevertheless, this route of infection has several disadvantages. E.g., intranasal inoculation stimulates sneezing which may result in less volume of Cpn-containing solution, and thus less infectious particles, in the lungs. Also, it has the risk of inoculation of the stomach instead of lungs. Overall, it is difficult to standardize the amount of inclusion forming units when mice become infected intranasally. In contrast, intratracheal inoculation does not seem to have the disadvantages of intranasal inoculation. However, dissemination profiles, in particular to the vascular wall, following intratracheal infection have 
not been determined so far. Alternatively, intraperitoneal injections have been used to infect mice. Although this may not be the natural route of infection, it has been shown to result in the prominent presence of Cpn DNA in the vascular tree. To decide which route of infection is most appropriate to study the effects of Cpn on atherosclerosis, we determined systemic dissemination of Cpn to target organs, especially the vascular wall, after both intratracheal and intraperitoneal infection. In Chapter 2, we demonstrated that Cpn has the ability to disseminate systemically after intratracheal and intraperitoneal. Intraperitoneal Cpn infection induces systemic dissemination to the vascular tree that contains Cpn DNA up till 6 days after infection. Intratracheal Cpn infection results in systemic dissemination as well, although significantly lower Cpn DNA copy numbers were observed in the vascular tree at 4 and 6 days post infection. Thus, intraperitoneal inoculation of Cpn is the preferred inoculation route in mice to study the effect of Cpn infection on atherosclerotic lesion progression and was therefore used in future experiments.

\section{Cpn and atherosclerosis}

\section{Animal models}

To study the pathogenesis and mechanisms involved in atherosclerosis, different animal models, including mice, rats and rabbits, have been used in the past. Nevertheless, mouse models are generally favoured over rabbits or rats because of the possibility to easily create knockout and transgenic mouse strains. In this thesis, three different mouse strains have been used. First, the Apolipoprotein E (ApoE)3-Leiden strain was used in Chapter 3 to study the effect of Cpn infections on lesion development. This strain develops advanced lesions only when fed a high cholesterol diet and lesion formation is quite protracted. ${ }^{13,14}$ This is in contrast to the Apolipoprotein E, low density lipoprotein receptor (ApoE-/-LDLr-/-) double knockout strain, which develops advanced lesion already within 3 months even without additional diet (Chapter 5). ${ }^{15}$ Finally, we used the C57BL/6J strain, which develops early lesions only even when fed an additional high cholesterol diet (Chapter 4). ${ }^{16}$ The use of these three mouse strains allowed us to discriminate between the effects of Cpn on either initial or advanced lesion.

\section{Effect of Cpn on early lesions}

In Chapter 3, ApoE3-Leiden transgenic mice, fed a high fat/high cholesterol diet, were infected at a young age (9 weeks) when only initial lesions are present. When the effect of Cpn was evaluated shortly after infection (1 month), no effect was observed either on lesion size, number or type. This is in accordance with data from other groups who also could not demonstrate an effect on plaque development early after inoculation. ${ }^{17-19}$ In contrast, others have demonstrated that the effect of Cpn on atherosclerosis becomes more prominent later on and that repetitive inoculations might be required. ${ }^{17}$ Indeed, we were able to demonstrate a significant enlargement in lesion size in 14 months old C57BL/6J mice following multiple Cpn infections. Otherwise, no effect of Cpn on lesion size was observed in 8 and 11 months old ApoE3-Leiden transgenic mice. As these mice were infected only twice, this supports 
the idea that multiple infections are needed before a prominent effect of Cpn on lesion size can be observed.

Apart from lesion size, we also evaluated the complexity of the lesion as this is generally considered as clinically more relevant than lesion size. Despite a prolonged atherogenic diet, no advanced lesions were found in 14 months old C57BL/6J mice following multiple Cpn infections suggesting that additional factors might be required for the development of advanced lesions. Interestingly, we only found slightly, and non-significantly, elevated cholesterol and triglyceride levels in these mice. This suggests that in the absence of high plasma cholesterol levels, repetitive Cpn infections are sufficient to increase lesion size, but that high cholesterol levels are required for the development of advanced lesions. This is supported by our findings in ApoE3-Leiden transgenic mice. In these mice, which develop significantly higher cholesterol and triglyceride levels than C57BL/6J mice, complex lesions were found in 8 and 11 months old mice. Furthermore, although two Cpn infections were obviously insufficient to increase lesion size, a significant acceleration in advanced lesion formation was observed at 6 and 9 months post infection. Summarizing, our results indicate that repetitive infections are mandatory before Cpn affects lesion size. Alternatively, once the circumstances are created for the formation of advanced lesions, less frequent Cpn infections seems to be needed to accelerate this process.

\section{Effect of Cpn on advanced lesions}

Clinical symptoms of cardiovascular disease usually results from plaque rupture, thrombus formation and ultimately occlusion of the vascular lumen. As Cpn has been frequently associated with stroke and myocardial infarction, it is hypothesised that Cpn plays a role in plaque destabilisation and increase the risk for future insults. To test whether Cpn affect the stability of an advanced lesion, we infected ApoE-/-/LDLr-/- mice with Cpn. In these mice, advanced lesion can already be found at a rather young age ( 3-4 months) even when these mice are fed a normal chow diet. Thus, 16 week old mice were infected twice and sacrificed at an age of 20 weeks. Similarly, mice were infected once every 2 weeks and sacrificed at 40 weeks of age or observed until natural death. Surprisingly, neither 2 nor 6 consecutive Cpn infections resulted in significant alterations in lesion type or size. This suggests that, in contrast to our findings in infected mice with only initial lesions, Cpn does not alter size or complexity of already advanced lesions. The reason for this discrepancy remains to be established. If $\mathrm{Cpn}$ is more tropic to cells that contribute to fatty streaks, the early lesion in atherosclerosis, or if the microenvironment of the fatty streak favors the replication of Cpn more than that of a fibrous plaque, it is possible that Cpn cause more inflammation in early lesions than in advanced lesion. This is supported by our finding that the number of T-cells was significantly increased in lesions of mice infected already at a young age (Chapter 3). Also, early lesions from infected 14 months old C57BL/6J mice stained more positive for serum amyloid $P$ than lesions form mock injected mice, suggesting higher levels of local inflammation (Chapter 4). Thus, Cpn effects on lesion size and/or type seem to be restricted to initial lesions.

Nevertheless, when advanced lesions in the infected ApoE-/-/LDLr-/- mice were studied in more detail, remarkable signs of plaque destabilization were found in lesions from infect- 
ed mice. More precisely, in both groups (infected twice or 6 times) a significant increase in the size of the necrotic core was observed while the fibrous cap of the lesions was significantly diminished. Thus, $\mathrm{Cpn}$ infection modifies several markers of plaque stability, thereby inducing the formation of a more unstable, and consequently more rupture prone plaque phenotype. The clinical significance of this was illustrated in the survival experiment. When mice were infected 6 times and observed until natural death a significant reduction in life expectancy was observed in the infected group compared to the mock injected group. Furthermore, autopsy revealed signs of (healed) myocardial infarcts in some of the mice providing evidence that these mice might indeed have succumbed to complication of atherosclerosis.

It is well established that activated macrophages, which are essential components in atherosclerotic plaques, are able to produce and secrete matrix metalloproteinases (MMPs) like collagenases, elastases and stromelysins ${ }^{20}$ that can degrade the fibrous cap, ultimately leading to a vulnerable plaque with a high risk of rupture. Recently, it now has been shown that $\mathrm{Cpn}$ is able to induce MMP activity directly in monocytes through an extracellular matrix metalloproteinase inducer (EMMPRIN)-dependent pathway and indirectly in smooth muscle cells via monocyte-derived cytokines. ${ }^{21}$ Furthermore, evidence suggests that exposure of human monocytes or smooth muscle cells to $\mathrm{Cpn}$ results in a significant enhancement in the production of various MMPs. ${ }^{22-24}$ In line with this we found a significant upregulation of MMP-2 and -9 immunoreactivity in plaques of ApoE-//LDLr-/- mice both after 2 and 6 inoculations which may provide a possible explanation for the observed destabilisation of the fibrous plaque. Although a marked up-regulation of both MMP antigens in the lesions was observed, activity, measured by zymography or mRNA expression levels were similar in both groups. This suggests that a role for these specific MMPs is less likely which is in accordance with data from others. Rodel and co-workers demonstrated a lack of effect of Cpn infection on MMP-2 and -9 mRNA levels in smooth muscle cells. ${ }^{23}$ Also, no association between the presence of Cpn DNA and increased activity of MMP-2 and -9 could be demonstrated in aneurysmatic abdominal aortas, ${ }^{25}$ indicating a minor role for these specific MMPs in murine plaque destabilisation following $\mathrm{Cpn}$ infection. Nevertheless, in the mean time other corrosive enzymes, such as collagenases (MMP-1 and -8) and stromelysins (MMP3), have been associated with Cpn infection and should be subject for further study. Furthermore, a limitation of our study (Chapter 5) is that the activity of tissue inhibitors of the MMPs (TIMPs) was not investigated. Increased activity of these TIMPs may result in decreased MMP activity in the vascular tissue. Another topic for future study is MMP-2 and -9 expression at protein level by western blot. However, to study TIMPs activity and MMP2 and -9 protein expression a new group of atherosclerotic aortic arches from ApoE-/-LDLr/- mice are needed.

\section{Antibiotics as future therapy for atherosclerosis?}

The macrolide class of antibiotics is well established and often recommended for use in the treatment of community-acquired respiratory tract infection caused for example by $\mathrm{Cpn}$. The availability of these drugs and the suggested association between Cpn, inspired 
researchers already in the late 1990' to test whether antimicrobial therapy may be helpful in the secondary prevention of CAD. ${ }^{6}$ Initial clinical studies reported that antibiotic therapy might lead to large reductions in secondary cardiovascular risk in patients with stable coronary heart disease or acute coronary syndromes (table 1). ${ }^{6,26-28}$ However, subsequent studies of intermediate size failed to confirm a large benefit, ${ }^{27,29-31}$ although these studies left open the possibility of limited-to-moderate clinical benefits. To test this possibility, large randomised trails involving thousands of patients were accordingly initiated (ACES, WIZARD, PROVE-IT, AZACS). Nevertheless, no significant benefits of antimicrobial therapy for the secondary prevention of cardiovascular events after acute coronary syndromes were observed, even when large patients groups were included or when therapy was given over the long term. Consequently, the results of these trails seriously questioned the validity of the infection hypothesis.

Nevertheless, although some of the initial comment on the first trails (small sample size, short treatment schedule of infection, short follow-up) were counteracted in the later trails, there are still some critical remarks concerning the trails that ought to be resolved before the hypothesis should be considered as false. The first issue that has to be clarified is time point at which the treatment is started. As it is not uncommon that a person becomes infected with Cpn already early in life, while the clinical signs and symptoms of atherosclerosis do not become manifest until the $6^{\text {th }}$ decade, it is questionable whether treatment at this late time point is effective. Furthermore, Cpn infections are frequently sub-clinical, not treated or inefficiently treated with broad-spectrum antibiotics. Nevertheless, as our data in Chapter 6 demonstrate, treatment of acute infection might be beneficial in preventing acute effects of Cpn infection.

Secondly, it can not be excluded that the antibiotic regimen is ineffective. Indeed, Gieffers et al. found that Cpn infection in vitro in monocytes from healthy volunteers was refractory to azithromycin as antibiotic treatment did not inhibit chlamydial growth within monocytes, and after withdrawal of antibiotic therapy, Cpn could be cultured from monocyte cell lines. Similar results were obtained with circulating monocytes from patients who had been treated for coronary heart disease ${ }^{32}$ Accordingly when we treated our mice immediately after infection with azithromycin we were unable to eradicate Cpn completely in at least 4 out of 7 mice providing further evidence for the ineffectiveness of currently available antibiotics for the treatment of $\mathrm{Cpn}$, although it remains to be determined whether quinolones show a similar ineffectiveness in Cpn clearance. Nevertheless, we were able to prevent the development of vulnerable plaques in infected mice demonstrating that azithromycin was effective at least to some extent. However, it remains to be established to what extent this effect is attributable, is it an antimicrobial effect or a more general anti-inflammatory effect, as has recently been suggested by others. . $^{33-36}$

Thirdly, if infections indeed contribute to atherosclerosis it is unlikely that only one microorganisms is able to influence this process. In fact multiple micro-organisms have been associated with atherosclerosis over the past two decades. Also, several reports have suggested that multiple infections augment the risk conveyed by a single pathogen, the so called "pathogen burden" hypothesis. ${ }^{37-39}$ This hypothesis has been confirmed by a number of prospective studies demonstrating that an increased pathogen burden is inversely relat- 
ed to the long-term prognosis in patients with documented coronary artery disease. ${ }^{40,41} \mathrm{Also}$, an increased pathogen burden may be an independent risk factor for endothelial dysfunction, one of the earliest manifestations of atherogenesis. ${ }^{42}$ This makes it doubtful that treatment with a single antibiotic might be sufficient to eliminate infections as a risk factor for atherosclerosis.

Finally, it has recently been suggested that the contribution of infection, and in particular Cpn, to atherosclerosis is independent of the direct effects of the microbe, but is due to cross-reactivity between microbial proteins and self-proteins. In particular, autoimmune reactions directed against heat shock protein 60 (HSP60) have been suggested as an important etiological factor in atherosclerosis. ${ }^{43}$ HSP60 are phylogenetically highly conserved and there is an over 55\% homology between bacterial hsp60 and the human homologue forming the basis for this cross-reactivity. Once infected, the organism will develop initiate and adaptive cellular and humoral immunity towards, among others, microbial HSP60 epitopes. As these epitopes share a homology with self HSP60, it may be anticipated that cross-reactivity develops. Now, in cases where endothelial cells are maltreated - e.g. by high blood pressure, high cholesterol or smoking - HSP60 is expressed on the endothelial surface and we have to 'pay' for our protective anti-HSP60 immunity by endothelial damage and the subsequent development of early atherosclerotic lesions. ${ }^{44}$ In this alternative hypothesis explaining the effect of infections on atherosclerosis, it is doubtful that antimicrobial therapy for secondary prevention may be useful.

In summary, although the results of most large clinical trails evaluating the effects of antimicrobial therapy were rather disappointing, there a still a number of critical questions have to be addressed before the definite conclusion can be drawn that infection is not atherogenic. Furthermore, in contrast to the time point when treatment was started in most trails (usually following an initial cardiovascular event and not following an infection), our results suggests that antimicrobial therapy may be effective if treatment is started immediately after infection. However due to the difficulties in diagnosing $\mathrm{Cpn}$ infection in daily practice this might may be rather impractical to evaluate in clinical trails.

\section{Concluding remarks and future perspectives}

In this thesis, we tried to unravel some of the mechanisms involved in Cpn-induced development and/or progression of atherosclerosis by using several mouse models.

Before studying the effect of $\mathrm{Cpn}$ on atherosclerotic lesion progression, the "ideal" route of $\mathrm{Cpn}$ inoculation in mice was evaluated. We showed that intraperitoneal inoculation of $\mathrm{Cpn}$ and not intratracheal inoculation, induced higher Cpn DNA copy numbers in vascular tissue material which makes it the preferred inoculation route. When young ApoE3-Leiden transgenic mice were inoculated intraperitoneally with Cpn, no effect was seen on initial atherosclerotic lesions but an acceleration in advanced lesion type was observed. Moreover, multiplicity of infections was essential. In C57BL/6J mice following $10 \mathrm{Cpn}$ infections, a significant enlargement in lesion size was observed, while in ApoE3-Leiden transgenic mice, inoculated only twice with $\mathrm{Cpn}$, no effect on lesion size was observed. When old mice with advanced lesions were inoculated with Cpn, no effect on lesion type nor T- 
cells was observed. Thus, Cpn infection in the presence of early atherosclerotic lesions results in modification of lesion type and T-cell influx, whereas infection of mice with advanced lesions modifies markers of plaque stability, inducing the formation of a more unstable plaque phenotype. These effects were more pronounced when mice were followed for a longer time period. A reduction in survival occurred in the Cpn-infected mice probably due to enhanced cardiovascular complications. The molecular mechanism that may explain these observations is the marked upregulation of MMP-2 and -9. Although we observed a marked up-regulation of both MMP antigens in the plaque of Cpn-infected mice, MMP activity and mRNA expression levels were similar in both groups. This suggests that a role for these specific MMPs is less likely. Nevertheless, other enzymes, such as MMP-1, -8 and MMP-3, have been associated with Cpn infection and should be subject for further study. Furthermore, in our study (Chapter 5) the activity of tissue inhibitors of the MMPs (TIMPs) was not investigated. Increased activity of these TIMPs may result in a failure to disclose an increased MMP activity in the vascular tissue. Another interesting topic for future study is MMP-2 and -9 expression at protein level by western blot. Finally, we determined whether the effect of Cpn on formation of unstable plaques can be prevented by antibiotic therapy. Indeed, we observed more stable lesions after treatment with azithromycin. However, these observations were also present in uninfected control mice treated with azithromycin, which suggests that azithromycin probably not only has anti-microbial but also anti-inflammatory capacities. Several other issues concerning secondary prevention through antibiotic therapy should be taken into consideration. Especially since the results of most large clinical trails evaluating the effects of antimicrobial therapy were rather disappointing. The first issue that has to be clarified is time point at which the treatment is started. We showed that treatment of acute infection might be beneficial in preventing acute effects of Cpn infection. However treating patients after every acute Cpn infection, which often is subclinical, is impracticable. Secondly, currently available antibiotics for the treatment of Cpn, might be ineffective. In our mice, which were treated with azithromycin immediately after infection we were unable to eradicate Cpn completely in at least 4 out of 7 mice. Moreover, if infections indeed contribute to atherosclerosis it is unlikely that only one micro-organisms is able to influence this process. It is more likely that "pathogen burden" (multiple different pathogens) is associated with progression of atherosclerotic cardiovascular disease. ${ }^{40-42}$ This makes it doubtful that treatment with a single antibiotic might be sufficient to eliminate infections as a risk factor for atherosclerosis. Future intervention trials for further study of the role of pathogen burden in progression of atherosclerotic cardiovascular disease, may give us insight in this multifactorial systemic disease. Until then transgenic and knockout mouse strains can be used to evaluate new risk factors for progression of cardiovascular disease. 


\begin{tabular}{|c|c|c|c|c|c|c|c|}
\hline Name/Author (year) & $\mathrm{N}$ & Clinical condition & Therapy & Duration & Follow-up & End-points & Results \\
\hline \multicolumn{8}{|c|}{ Peripheral vascular disease } \\
\hline Masorin et al. ('01) & 32 & AAA & doxy. $150 \mathrm{mg}$ daily & 3 months & 18 months & aneurysm expansion & $\begin{array}{l}\text { significant } \downarrow \text { in expansion in treated } \\
\text { group }\end{array}$ \\
\hline Wiesli et al. ('02) & 40 & PAOD & roxi. $300 \mathrm{mg}$ daily & 28 days & 2.7 years & revascularisation & $\begin{array}{l}\text { significant } \downarrow \text { in revascularisation, } \uparrow \\
\text { walking distance, } \downarrow \text { carotid plaque } \\
\text { area }\end{array}$ \\
\hline Parchure et al. ('02) & 40 & CAD & $\begin{array}{l}\text { azithro. } 500 \mathrm{mg} 3 \mathrm{~d} \text {, then } \\
\text { 500mg weekly }\end{array}$ & 5 weeks & 5 weeks & FMD brachial artery & $\begin{array}{l}\text { significant } \uparrow \text { in FMD dilatation in } \\
\text { treated group }\end{array}$ \\
\hline Sander et al. ('02) & 272 & Ischemic stroke & roxi. 150mg 2t .daily & 30 days & 2 years & decrease IMT & $\begin{array}{l}\text { significant } \downarrow \text { IMT in Cpn+ treated } \\
\text { group no difference in } \\
\text { cardiovascular events, after } 3,4 \\
\text { years no } \downarrow \text { IMT }\end{array}$ \\
\hline Vainas et al. ('05) & 509 & PAOD & azithro. $500 \mathrm{mg}$ daily & 3 days & 2 years & $\begin{array}{l}\text { death, cardiovasc. } \\
\text { events, } \downarrow \text { ABPI }\end{array}$ & No effect on survival, ABPI \\
\hline \multicolumn{8}{|l|}{ Coronary artery disease } \\
\hline Gupta et al. ('97) & 60 & Post-MI & $\begin{array}{l}\text { azithro. } 500 \mathrm{mg} \text { 3d., then } \\
500 \mathrm{mg} \text { for } 6 \mathrm{~d} \text {. }\end{array}$ & 9 days & 18 months & death, MI, revasc. & significant $\downarrow$ in EP in treated group \\
\hline Sinisalo et al. ('02) & 148 & UA, MI & clari. $500 \mathrm{mg}$ daily & 3 months & 18.5 months & $\begin{array}{l}\text { death, MI, UA (1 EP) } \\
\text { death, MI, UA, stroke, } \\
\text { limb ischemia (2 EP) }\end{array}$ & $\downarrow$ in 2 nd endpoints at 18.5 months \\
\hline Gurfinkel et al. ('97) & 202 & UA, MI & roxi.150mg twice daily & 30 days & 6 months & $\begin{array}{l}\text { cardiac ischemic death } \\
\mathrm{MI} \text {, recurrent ischemia }\end{array}$ & $\begin{array}{l}\text { At } 30 \text { days, significant } \downarrow \text { in EP, no } \\
\text { difference at } 6 \text { months }\end{array}$ \\
\hline Anderson et al. ('99) & 302 & Stable CAD & $\begin{array}{l}\text { azithro. } 500 \mathrm{mg} 3 \mathrm{~d} \text {., then } \\
500 \mathrm{mg} \text { weekly }\end{array}$ & 3 months & 2 years & death, MI,stroke, UA, & $\begin{array}{l}\text { significant } \downarrow \text { CRP, IL-6, no revasc. } \\
\text { difference in EP }\end{array}$ \\
\hline Stone et al. ('02) & 325 & ACS & $\begin{array}{l}\text { amoxi+metro+ome } \\
\text { azitro+metro+ome }\end{array}$ & 1 week & 1 year & MI, UA & $\begin{array}{l}\downarrow \text { in endpoints with either therapy } \\
\text { schedule }\end{array}$ \\
\hline Zahn et al. ('03) & 872 & MI & roxi. $300 \mathrm{mg}$ & 6 weeks & 12 months & $\begin{array}{l}\text { 1EP:total mortali ty } \\
\text { 2EP:death, reinfarct. }\end{array}$ & no difference in 1 ep or 2 nd ep \\
\hline Neumann et al. ('01) & 1010 & Post-stenting & roxi. $300 \mathrm{mg}$ daily & 28 days & 6 months & $\begin{array}{l}\text { CVA, revasc., UA } \\
\text { restenosis, death, } \\
\text { revasc., MI }\end{array}$ & $\begin{array}{l}\text { significant } \downarrow \text { restenosis in treated } \\
\text { group }\end{array}$ \\
\hline Cercek et al. ('03) & 1400 & UA & $\begin{array}{l}\text { azitro. } 500 \mathrm{mg} .1 \text { day, then } \\
250 \mathrm{mg} 4 \text { days }\end{array}$ & 5 days & 6 months & mortality, MI, revasc. & no difference in EP \\
\hline Jackson et al. ('05) & 4012 & Stable CAD & azitro. $600 \mathrm{mg}$ weekly & 1 year & 3.9 years & $\begin{array}{l}\text { CVD, MI, revasc., } \\
\text { hospital for UA }\end{array}$ & no difference in EP \\
\hline Cannon et al. ('05) & 4162 & Post-MI, UA & $\begin{array}{l}\text { gatifloxacin } 400 \mathrm{mg} \text { daily for } \\
2 \text { weeks, then } 10 \text { day course } \\
\text { monthly }\end{array}$ & 2 years & 2 years & $\begin{array}{l}\text { death, MI, stroke, } \\
\text { hospitalisation }\end{array}$ & no difference in EP \\
\hline Coletta et al.('02) & 7724 & Post MI & $\begin{array}{l}\text { azithro. } 600 \mathrm{mg} 3 \mathrm{~d} ., \text { then } \\
600 \mathrm{mg} \text { weekly }\end{array}$ & 11 weeks & 2 years & $\begin{array}{l}\text { composite: mortality, } \\
\text { recurrent } \mathrm{MI} \text {, revasc., } \\
\text { hospitalisation for } \mathrm{MI}\end{array}$ & no difference in EP \\
\hline
\end{tabular}

$\overrightarrow{\vec{G}} \quad$ Table 1: Summary of trials of the effect of antibiotic therapy on cardiovascular diseases. Update from Gelfand et al. ${ }^{45}$ 


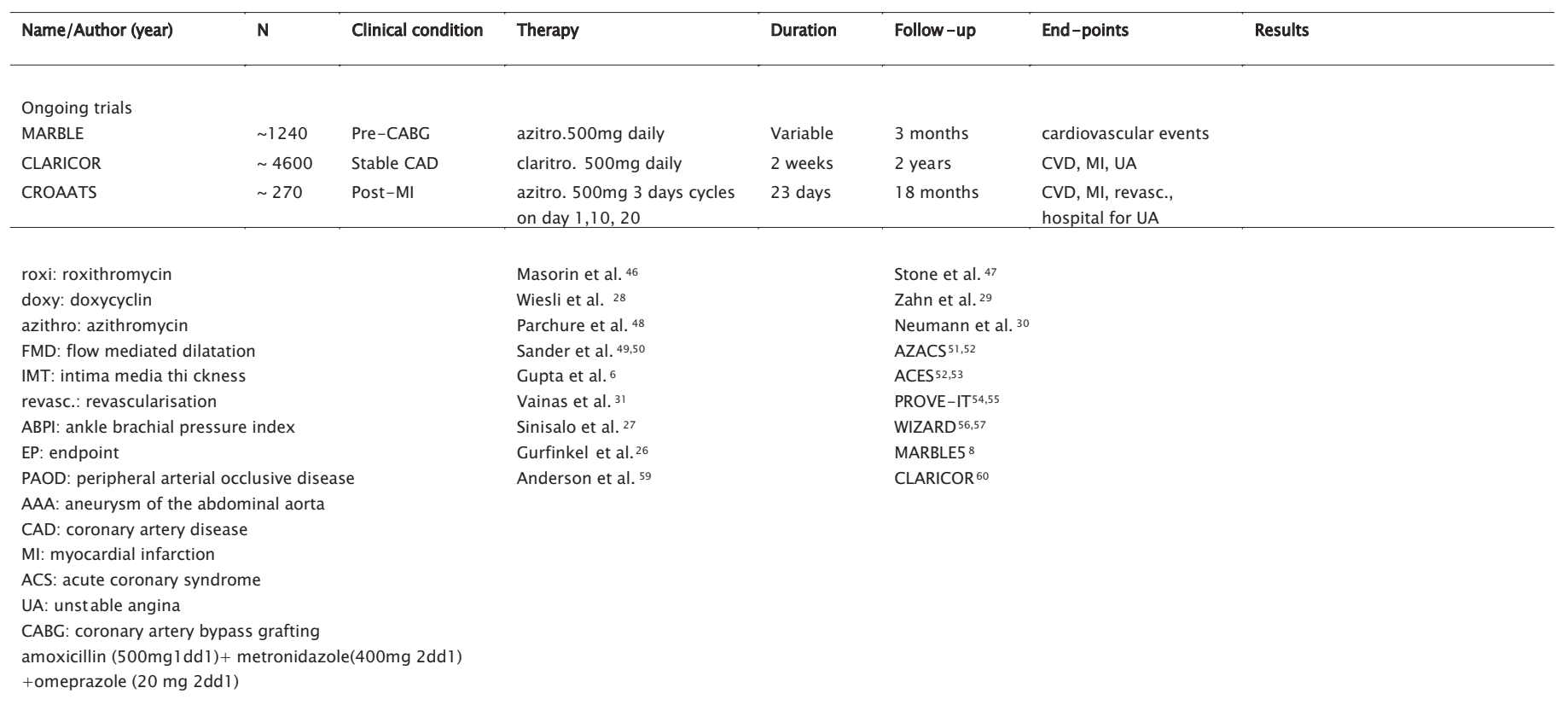




\section{References}

1. Frothingham $\mathrm{C}$. The relationship between acute infectious diseases and arterial lesions. Arch Intern Med. 1911;8:153-162.

2. Klotz O, Manning M. Fatty streaks in intima of arteries. J Pathol Bacteriol. 1912;16:211-220.

3. Osler W. Diseases of the arteries. In: Osler W, ed. Modern Medicine: Its Practice and Theory. Philadelphia: Lea and Febiger; 1908:429-447.

4. Saikku P, Leinonen M, Mattila K, Ekman MR, Nieminen MS, Makela PH, Huttunen JK, Valtonen V. Serological evidence of an association of a novel Chlamydia, TWAR, with chronic coronary heart disease and acute myocardial infarction. Lancet. 1988;2:983-6.

5. Fabricant CG, Fabricant J, Litrenta MM, Minick CR. Virus-induced atherosclerosis. J Exp Med. 1978;148:335-40.

6. Gupta S, Leatham EW, Carrington D, Mendall MA, Kaski JC, Camm AJ. Elevated Chlamydia pneumoniae antibodies, cardiovascular events, and azithromycin in male survivors of myocardial infarction. Circulation. 1997;96:404-7.

7. Campbell LA, O'Brien ER, Cappuccio AL, Kuo CC, Wang SP, Stewart D, Patton DL, Cummings PK, Grayston JT. Detection of Chlamydia pneumoniae TWAR in human coronary atherectomy tissues. J Infect Dis. 1995;172:585-8.

8. Ramirez JA. Isolation of Chlamydia pneumoniae from the coronary artery of a patient with coronary atherosclerosis. The Chlamydia pneumoniae/Atherosclerosis Study Group. Ann Intern Med. 1996;125:979-82.

9. Stratton CW, Sriram S. Association of Chlamydia pneumoniae with central nervous system disease. Microbes Infect. 2003;5:1249-53.

10. Furrows SJ, Hartley JC, Bell J, Silver N, Losseff N, Stevenson S, Chapman M, Thompson EJ, Ridgway GL, Giovannoni G. Chlamydophila pneumoniae infection of the central nervous system in patients with multiple sclerosis. J Neurol Neurosurg Psychiatry. 2004;75:152-4.

11. Hannu T, Puolakkainen M, Leirisalo-Repo M. Chlamydia pneumoniae as a triggering infection in reactive arthritis. Rheumatology (Oxford). 1999;38:411-4.

12. Grayston JT. Infections caused by Chlamydia pneumoniae strain TWAR. Clin Infect Dis. 1992;15:757-61.

13. Lutgens E, Daemen M, Kockx M, Doevendans P, Hofker M, Havekes L, Wellens $H$, de Muinck ED. Atherosclerosis in $\mathrm{APOE}^{\star} 3$-Leiden transgenic mice: from proliferative to atheromatous stage. Circulation. 1999;99:276-83.

14. van Vlijmen BJ, van den Maagdenberg AM, Gijbels MJ, van der Boom $\mathrm{H}$, HogenEsch $\mathrm{H}$, Frants RR, Hofker MH, Havekes LM. Diet-induced hyperlipoproteinemia and atherosclerosis in apolipoprotein E3-Leiden transgenic mice. J Clin Invest. 1994;93:1403-10.

15. Caligiuri C, Levy B, Pernow J, Thoren P, Hansson G. Myocardial inferction mediated by endothelin receptor signaling in hypercholesterolemic mice. Proc Natl Acad Sci USA. 1999;96:6920-6924.

16. Ezzahiri R, Stassen FR, Kurvers HR, Dolmans V, Kitslaar PJ, Bruggeman CA. Chlamydia pneumoniae infections augment atherosclerotic lesion formation: a role for serum amyloid P. Apmis. 2006;114:117-26.

17. Hu H, Pierce GN, Zhong G. The atherogenic effects of chlamydia are dependent on serum cholesterol and specific to Chlamydia pneumoniae. J Clin Invest. 1999;103:747-53.

18. Liu L, Hu H, Ji H, Murdin AD, Pierce GN, Zhong G. Chlamydia pneumoniae infection significantly exacerbates aortic atherosclerosis in an LDLR-/- mouse model within six months. Mol Cell Biochem. 2000;215:123-8. 
19. Rothstein NM, Quinn TC, Madico G, Gaydos CA, Lowenstein CJ. Effect of azithromycin on murine arteriosclerosis exacerbated by Chlamydia pneumoniae. J Infect Dis. 2001;183:232-238.

20. Galis Z, Sukhova G, Lark M, Libby P. Increased expression of matrix metalloproteinases and matrix degrading activity in vulnerable regions of human atherosclerotic plaques. $J$ Clin Invest. 1994;94:2493-2503.

21. Schmidt R, Redecke V, Breitfeld Y, Wantia N, Miethke T, Massberg S, Fischel S, Neumann FJ, Schomig A, May AE. EMMPRIN (CD 147) is a central activator of extracellular matrix degradation by Chlamydia pneumoniae-infected monocytes. Implications for plaque rupture. Thromb Haemost. 2006;95:151-8.

22. Kol A, Sukhova GK, Lichtman AH, Libby P. Chlamydial heat shock protein 60 localizes in human atheroma and regulates macrophage tumor necrosis factor-alpha and matrix metalloproteinase expression. Circulation. 1998;98:300-7.

23. Rodel J, Prochnau D, Prager K, Pentcheva E, Hartmann M, Straube E. Increased production of matrix metalloproteinases 1 and 3 by smooth muscle cells upon infection with Chlamydia pneumoniae. FEMS Immunol Med Microbiol. 2003;38:159-64.

24. Kim MP, Gaydos CA, Wood BJ, Hardick JP, Zhang Y, Wahl LM. Chlamydia pneumoniae enhances cytokine-stimulated human monocyte matrix metalloproteinases through a prostaglandin E2-dependent mechanism. Infect Immun. 2005;73:632-4.

25. Petersen E, Boman J, Wagberg F, Angquist KA. Presence of Chlamydia pneumoniae in abdominal aortic aneurysms is not associated with increased activity of matrix metalloproteinases. Eur J Vasc Endovasc Surg. 2002;24:365-9.

26. Gurfinkel E, Bozovich G, Daroca A, Beck E, Mautner B. Randomised trial of roxithromycin in non-Q-wave coronary syndromes: ROXIS Pilot Study. ROXIS Study Group. Lancet. 1997;350:404-7.

27. Sinisalo J, Mattila K, Valtonen V, Anttonen O, Juvonen J, Melin J, Vuorinen-Markkola H, Nieminen MS. Effect of 3 months of antimicrobial treatment with clarithromycin in acute non-q-wave coronary syndrome. Circulation. 2002;105:1555-60.

28. Wiesli P, Czerwenka W, Meniconi A, Maly FE, Hoffmann U, Vetter W, Schulthess G. Roxithromycin treatment prevents progression of peripheral arterial occlusive disease in Chlamydia pneumoniae seropositive men: a randomized, double-blind, placebo-controlled trial. Circulation. 2002;105:2646-52.

29. Zahn R, Schneider S, Frilling B, Seidl K, Tebbe U, Weber M, Gottwik M, Altmann E, Seidel F, Rox J, Hoffler U, Neuhaus KL, Senges J. Antibiotic therapy after acute myocardial infarction: a prospective randomized study. Circulation. 2003;107:1253-9.

30. Neumann F, Kastrati A, Miethke T, Pogatsa-Murray G, Mehilli J, Valina C, Jogethaei N, da Costa CP, Wagner H, Schomig A. Treatment of Chlamydia pneumoniae infection with roxithromycin and effect on neointima proliferation after coronary stent placement (ISAR-3): a randomised, double-blind, placebo-controlled trial. Lancet. 2001;357:2085-9.

31. Vainas T, Stassen FR, Schurink GW, Tordoir JH, Welten RJ, van den Akker LH, Kurvers $\mathrm{HA}$, Bruggeman CA, Kitslaar PJ. Secondary prevention of atherosclerosis through chlamydia pneumoniae eradication (SPACE Trial): a randomised clinical trial in patients with peripheral arterial disease. Eur J Vasc Endovasc Surg. 2005;29:403-11.

32. Gieffers J, Fullgraf H, Jahn J, Klinger M, Dalhoff K, Katus HA, Solbach W, Maass M. Chlamydia pneumoniae infection in circulating human monocytes is refractory to antibiotic treatment. Circulation. 2001;103:351-6.

33. Hall IH, Schwab UE, Ward ES, Butts JD, Wolford ET, Ives TJ. Disposition and intracellular activity of azithromycin in human THP-1 acute monocytes. Int $\mathrm{J}$ Antimicrob Agents. 2002;20:348-60. 
34. Culic O, Erakovic V, Cepelak I, Barisic K, Brajsa K, Ferencic Z, Galovic R, Glojnaric I, Manojlovic Z, Munic V, Novak-Mircetic R, Pavicic-Beljak V, Sucic M, Veljaca M, ZanicGrubisic T, Parnham MJ. Azithromycin modulates neutrophil function and circulating inflammatory mediators in healthy human subjects. Eur J Pharmacol. 2002;450:277-289.

35. Uriarte SM, Molestina RE, Miller RD, Bernabo J, Farinati A, Eiguchi K, Ramirez JA, Summersgill JT. Effect of macrolide antibiotics on human endothelial cells activated by Chlamydia pneumoniae infection and tumor necrosis factor-alpha. J Infect Dis. 2002;185:1631-6.

36. Ianaro A, lalenti A, Maffia P, Sautebin L, Rombola L, Carnuccio R, luvone T, D'Acquisto F, Di Rosa M. Anti-inflammatory activity of macrolide antibiotics. J Pharmacol Exp Ther. 2000;292:156-63.

37. Epstein SE. The multiple mechanisms by which infection may contribute to atherosclerosis development and course. Circ Res. 2002;90:2-4.

38. Epstein SE, Zhu J, Burnett MS, Zhou YF, Vercellotti G, Hajjar D. Infection and atherosclerosis: potential roles of pathogen burden and molecular mimicry. Arterioscler Thromb Vasc Biol. 2000;20:1417-20.

39. Zhu J, Quyyumi AA, Norman JE, Csako G, Waclawiw MA, Shearer GM, Epstein SE. Effects of total pathogen burden on coronary artery disease risk and C-reactive protein levels. Am J Cardiol. 2000;85:140-6.

40. Zhu J, Nieto FJ, Horne BD, Anderson JL, Muhlestein JB, Epstein SE. Prospective study of pathogen burden and risk of myocardial infarction or death. Circulation. 2001;103:45-51.

41. Rupprecht HJ, Blankenberg S, Bickel C, Rippin G, Hafner G, Prellwitz W, Schlumberger W, Meyer J. Impact of viral and bacterial infectious burden on long-term prognosis in patients with coronary artery disease. Circulation. 2001;104:25-31.

42. Prasad A, Zhu J, Halcox JP, Waclawiw MA, Epstein SE, Quyyumi AA. Predisposition to atherosclerosis by infections: role of endothelial dysfunction. Circulation. 2002;106:184-90.

43. Wick G, Perschinka H, Millonig G. Atherosclerosis as an autoimmune disease: an update. Trends Immunol. 2001;22:665-9.

44. Wick G, Knoflach M, Xu Q. Autoimmune and inflammatory mechanisms in atherosclerosis. Annu Rev Immunol. 2004;22:361-403.

45. Gelfand EV, Cannon CP. Antibiotics for secondary prevention of coronary artery disease: an ACES hypothesis but we need to PROVE IT. Am Heart J. 2004;147:202-9.

46. Mosorin M, Juvonen J, Biancari F, Satta J, Surcel HM, Leinonen M, Saikku P, Juvonen T. Use of doxycycline to decrease the growth rate of abdominal aortic aneurysms: a randomized, double-blind, placebo-controlled pilot study. J Vasc Surg. 2001;34:606-10.

47. Stone AF, Mendall MA, Kaski JC, Edger TM, Risley P, Poloniecki J, Camm AJ, Northfield TC. Effect of treatment for Chlamydia pneumoniae and Helicobacter pylori on markers of inflammation and cardiac events in patients with acute coronary syndromes: South Thames Trial of Antibiotics in Myocardial Infarction and Unstable Angina (STAMINA). Circulation. 2002;106:1219-23.

48. Parchure N, Zouridakis EG, Kaski JC. Effect of azithromycin treatment on endothelial function in patients with coronary artery disease and evidence of Chlamydia pneumoniae infection. Circulation. 2002;105:1298-303.

49. Sander D, Winbeck K, Klingelhofer J, Etgen T, Conrad B. Enhanced progression of early carotid atherosclerosis is related to Chlamydia pneumoniae (Taiwan acute respiratory) seropositivity. Circulation. 2001;103:1390-5.

50. Sander D, Winbeck K, Klingelhofer J, Etgen T, Conrad B. Reduced progression of early carotid atherosclerosis after antibiotic treatment and Chlamydia pneumoniae seropositivity. Circulation. 2002;106:2428-33. 
51. Cercek B, Shah PK, Noc M, Zahger D, Zeymer U, Matetzky S, Maurer G, Mahrer P. Effect of short-term treatment with azithromycin on recurrent ischaemic events in patients with acute coronary syndrome in the Azithromycin in Acute Coronary Syndrome (AZACS) trial: a randomised controlled trial. Lancet. 2003;361:809-13.

52. Jackson LA. Description and status of the azithromycin and coronary events study (ACES). J Infect Dis. 2000;181 Suppl 3:S579-81.

53. Grayston JT, Kronmal RA, Jackson LA, Parisi AF, Muhlestein JB, Cohen JD, Rogers WJ, Crouse JR, Borrowdale SL, Schron E, Knirsch C. Azithromycin for the secondary prevention of coronary events. N Engl J Med. 2005;352:1637-45.

54. Cannon CP, McCabe CH, Belder R, Breen J, Braunwald E. Design of the Pravastatin or Atorvastatin Evaluation and Infection Therapy (PROVE IT)-TIMI 22 trial. Am J Cardiol. 2002;89:860-1.

55. Cannon CP, Braunwald E, McCabe CH, Grayston JT, Muhlestein B, Giugliano RP, Cairns $\mathrm{R}$, Skene AM. Antibiotic treatment of Chlamydia pneumoniae after acute coronary syndrome. N Engl J Med. 2005;352:1646-54.

56. Dunne MW. Rationale and design of a secondary prevention trial of antibiotic use in patients after myocardial infarction: the WIZARD (weekly intervention with zithromax [azithromycin] for atherosclerosis and its related disorders) trial. J Infect Dis. 2000;181 Suppl 3:S572-8.

57. Coletta A, Thackray S, Nikitin N, Cleland JG. Clinical trials update: highlights of the scientific sessions of The American College of Cardiology 2002: LIFE, DANAMI 2, MADIT-2, MIRACLE-ICD, OVERTURE, OCTAVE, ENABLE 1 \& 2, CHRISTMAS, AFFIRM, RACE, WIZARD, AZACS, REMATCH, BNP trial and HARDBALL. Eur J Heart Fail. 2002;4:381-8.

58. Gupta S. Chlamydia pneumoniae, monocyte activation, and azithromycin in coronary heart disease. Am Heart J. 1999;138:S539-41.

59. Anderson JL, Muhlestein JB, Carlquist J, Allen A, Trehan S, Nielson C, Hall S, Brady J, Egger M, Horne B, Lim T. Randomized secondary prevention trial of azithromycin in patients with coronary artery disease and serological evidence for Chlamydia pneumoniae infection: The Azithromycin in Coronary Artery Disease: Elimination of Myocardial Infection with Chlamydia (ACADEMIC) study. Circulation. 1999;99:1540-7.

60. Hansen S, Als-Nielsen B, Damgaard M. Intervention with clarithromycin in patients with stable coronary heart disease: the CLARICOR Trial Design. Heart Drug. 2001;1:14-19. 
CHAPTER 8

Samenvatting 


\section{Samenvatting}

Atherosclerose is een multi-orgaan aandoening met een chronisch progressief karakter. Er wordt algemeen aangenomen dat inflammatie van de vaatwand aan de basis van dit proces ligt. Naast bekende oorzaken van inflammatie, als roken en hypertensie zijn er aanwijzingen dat ook infecties met Chlamydia pneumoniae (Cpn) een rol spelen in de progressie van atherosclerose. In dit proefschrift worden verschillende mogelijke mechanismen beschreven waardoor Cpn infectie kan leiden tot progressie van atherosclerotisch vaatlijden. Daarbij is het effect van Cpn infectie op zowel vroege als complexe atherosclerotische lesies bestudeerd. Ook is het effect van multipele Cpn infecties op lesie ontwikkeling geanalyseerd in normale (hoofdstuk 4) en atherosclerotische muizen (hoofdstuk 3 en 5). Tot slot is het effect van antibiotische therapie op het remmen danwel voorkomen van progressie van atherosclerose na Cpn infectie bestudeerd (hoofdstuk 6).

Hoofdstuk 1 geeft een theoretische achtergrond van de etiologie en de pathofysiologie van atherosclerose voor zover relevant voor de beschreven studies. Hierbij wordt de bijdrage van inflammatie aan het atherosclerotisch proces in algemene zin beschreven en daarnaast wordt voornamelijk de rol van verschillende micro-organismen, met name Cpn, uiteengezet.

In hoofdstuk 2 wordt de systemische verspreiding van Cpn na intratracheale (it) and intraperitoneale (ip) infectie beschreven. Het doel van deze studie was na te gaan welke route van inoculatie superieur is om disseminatie van het micro-organisme naar, met name, de vaatwand te bereiken. Daarbij zijn C57BI6/J muizen, die als genetische achtergrond dienen bij het fokken van transgene en knockout muizen (ApoE3-Leiden, ApoE knockout, and LDL-receptor, ApoE dubbel knockout muizen), it of ip geïnjecteerd met Cpn waarna het aantal Cpn DNA kopieën in diverse organen werd bepaald. We vonden dat, hoewel Cpn een voornamelijk respiratoir pathogeen is, systemische verspreiding plaatsvond na zowel it als ip injectie. Daarbij werden na ip injectie significant meer Cpn DNA kopieën gemeten in de vaatwand dan na it inoculatie. Dit maakt ip inoculatie superieur aan it injectie. Daarom werden alle muizen uit de experimenten beschreven in dit proefschrift, ip geïnjecteerd met Cpn of controle.

In hoofdstuk 3 wordt het effect van Cpn infectie op progressie van atherosclerose, aan de hand van type en grootte van de lesie, beschreven alsmede de rol van Cpn op het inflammatoire proces in de vaatwand. Daarvoor werden ApoE3-Leiden transgene muizen geïnjecteerd met Cpn en op verschillende tijdstippen na infectie opgeofferd. De resultaten laten zien dat Cpn infectie leidt tot (1) een versnelde vorming van complexe atherosclerotische laesies op 6 en 9 maanden na infectie en (2) een sterk verhoogde influx van T-cellen in de plaque op 1 maand na infectie. Aangezien geactiveerde T-cellen een belangrijke bron van pro-inflammatoire en pro-atherogene cytokines vormen, kan gehypothetiseerd worden dat de verhoogde influx van T-cellen 
vroeg na infectie leidt tot een veranderde expressie van bepaalde cytokines. Op lange termijn zal dit resulteren in een versnelling van het atherosclerotisch proces zoals gemeten 6 en 9 maanden na infectie.

Om het effect van Cpn infectie op vroege atherosclerotische lesies te bestuderen werden C57BI6J muizen gebruikt (hoofdstuk 4). Aangezien deze muizen vroege atherosclerotische lesies ontwikkelen zelfs na atherogeen dieet, was de vraag of additionele multipele (10 maandelijkse) Cpn infecties zouden resulteren in de vorming van complexe lesies. We vonden dat $\mathrm{Cpn}$ niet resulteerde in progressie van lesie type maar resulteerde in een toename in lesie grootte (controle: $5022 \pm 1348 \mu \mathrm{m}^{2}$ vs Cpn: $\left.10821 \pm 2429 \mu \mathrm{m}^{2} ; \mathrm{p}=0.04\right)$. Daarmee gepaard gaande werd een toename van serum amyloid P (SAP) gemeten in atherosclerotische lesies (controle: $1.10^{-4} \pm 0.1 .10^{-4}$ SAP positieve cellen/lesie oppervlakte vs $\mathrm{Cpn}: 10.10^{-4} \pm 1.10^{-4}$ SAP positieve cellen/lesie oppervlakte; $p=0.05$ ).

In hoofdstuk 5 wordt de opbouw van complexe atherosclerotische lesies na Cpn infectie nader beschreven. We stelden de vraag of complexe lesies, ontstaan na Cpn infectie zoals beschreven in hoofdstuk 3, uiteindelijk zouden destabiliseren tot instabiele atherosclerotische lesies met op den duur een verhoogd risico op plaque ruptuur. Plaque ruptuur is het proces wat ten grondslag ligt aan ziektebeelden als hart- en herseninfarcten en acute perifere vaatafsluitingen. Er treedt afsluiting op van het desbetreffende bloedvat met ischemie van het aangedane weefsel en uiteindelijk weefselversterf.

In deze studie is gekozen voor ApoE,LDL-receptor dubbel knockout muizen die bekend staan om de snellere ontwikkeling van atherosclerotische lesies ten opzichte van ApoE3-Leiden muizen. Infectie van ApoE,LDL-receptor dubbel knockout muizen met Cpn resulteerde in een dunnere fibreuze cap, een toename in necrotische core en een toename van matrix metalloproteinase (MMP)-2 en -9 in de plaque, alle kenmerken van een instabiel plaque fenotype. Daarnaast vonden we een afname in overlevingsduur na Cpn infectie. De aanwezigheid van cardiovasculaire complicaties, geanalyseerd bij sectie van de proefdieren, was in beide groepen gelijk.

Om na te gaan of de Cpn-geinduceerde destabilisatie van de atherosclerotische lesie geremd of voorkomen kon worden, zijn ApoE,LDL-receptor dubbel knockout muizen geïnfecteerd met Cpn of controle en behandeld met azitromycine of sham therapie (hoofdstuk 6). We vonden dat Cpn-geïnfecteerde muizen, behandeld met azitromycine, minder complexe lesies vormden dan sham behandelde muizen, met minder lesie oppervlakte, necrotische core, T cellen influx en MMP-2 expressie. Het aandeel van de fibreuze cap in het plaque volume was toegenomen na antibiotica behandeling. Opmerkelijk was dat deze bevindingen ook waargenomen werden bij niet geïnfecteerde controle muizen die behandeld waren met antibiotica. Dus azitromycine voorkomt niet alleen de ontwikkeling van instabiel plaques in Cpn-geïnfecteerde ApoE,LDL-receptor dubbel knockout muizen, maar ook in controle geïn- 
jecteerde muizen. Dit suggereert dat azitromycine niet alleen antimicrobiële eigenschappen bezit maar ook anti-inflammatoire eigenschappen.

Tot slot worden in hoofdstuk 7 de belangrijkste resultaten van dit proefschrift bediscuseerd in relatie tot de literatuur. Er zijn in dit proefschrift verschillende muismodellen gebruikt om enkele mechanismen te belichten die betrokken zijn bij Cpn-geinduceerde progressie van atherosclerose. De resultaten tonen dat, in muisexperimenten, ip inoculatie van Cpn superieur is aan it inoculatie. Daarnaast suggereren de hier beschreven studies dat Cpn infectie in aanwezigheid van initiële lesies, zoals in de studie met ApoE3-Leiden muizen, resulteert in modificatie van lesie type en $\mathrm{T}$ cel influx, terwijl infectie van muizen met complexe lesies, zoals in de studie met ApoE,LDL-receptor dubbel knockout muizen, leidt tot veranderingen in plaque stabiliteit, naar een instabiel plaque fenotype. Dit proces kon voorkomen worden door vroege behandeling met azitromycine van Cpn-geïnfecteerde muizen, maar ook van niet geïnfecteerde controle muizen. Dit suggereert dat azitromycine zowel antimicrobiële als anti-inflammatoire eigenschappen bezit. 
Dankwoord 
Prof Kitslaar, bedankt voor uw bijdrage aan het onderzoek. U weet heel goed de zaken gestructureerd te formuleren zodat de boodschap van een verhaal veel duidelijker werd. Uw adviezen voor het geven van een goede presentatie op internationale congressen waren van onschatbare waarde.

Prof Bruggeman, bedankt voor de begeleiding, jouw snelle en nuttige commentaar op manuscripten is zeer waardevol geweest. Ik heb veel van je mogen leren tijdens de wekelijkse labbesprekingen en literatuurbesprekingen.

Dr Kurvers, jij hebt een zeer belangrijke bijdrage geleverd aan de fondsenwerving en daarmee aan de totstandkoming en continuïteit van dit onderzoek. Van een afstand heb je het onderzoek gevolgd en was je altijd bereid tot het geven van nuttige tips.

Dr Stassen, je bent later bij het promotie team gekomen. Bedankt voor al je waardevolle adviezen.

Gert en Selma, bedankt voor alle hulp op het lab, jullie hebben me alle labhandelingen geleerd die ik wilde weten voor het onderzoek, van ultradunne coupes snijden tot DNA isolatie van muizen aorta's en het kweken van tientallen flessen vasculaire endotheelcellen.

Alle dank aan mijn student-assistenten, Marloes van Pul, succes met je huisartsopleiding in Amsterdam, Valerie Dolmans, leuk dat we nu collega's zijn in Eindhoven, Lotte Kruidenier, succes met je onderzoek in Heerlen!

Alle medewerkers van het Centraal Proefdiervoorzieningen, jullie stonden altijd voor me klaar, ook in de weekenden als ik weer experimenten gepland had, kon ik altijd op jullie steun en inzet rekenen, bedankt!

Van het secretariaat Heelkunde wil ik alle dames bedanken in het bijzonder Yvonne Daemen voor de organisatie van alle logistieke zaken rondom de organisatie van een proefschrift. Dank ook aan alle dames van het lab: Jose, Angele en Fia.

Onder het motto: we zitten allemaal in hetzelfde schuitje, wil ik alle AIOS bedanken met wie ik heb samengewerkt: Inge, Ellen, Karen, Susan, Koen, Tryfon, Ruben, bedankt voor de geweldige tijd.

Verder wil ik Sineke Puister van Pfizer bedanken voor de prettige samenwerking.

Speciale dank aan Martien, Sacha, Minouche, Eus, bedankt voor jullie steun, vertrouwen en motivatie, jullie zijn geweldig.

Mijn grootste dank gaat uit naar de familie. Ondanks dat we zo ver van elkaar wonen, zo verschillend zijn en met zo veel, waren jullie altijd op de hoogte en stonden altijd voor me klaar. Ik hoop dat we zo close blijven als familie en dat ik nu eindelijk meer tijd kan doorbrengen met jullie in plaats van met de laptop. 
Curriculum Vitae 
Rajaa Ezzahiri is geboren op 8 februari 1976 te Breda. In 1994 deed ze eindexamen Gymnasium B aan het Newmancollege te Breda, waarna ze geneeskunde ging studeren aan de Universiteit Maastricht. Tijdens haar studie is ze actief bezig geweest als student-assistent (Dr Tordoir en Dr Lemson) en bij de oprichting van het eerste Maastricht Medical Student's Research Conference (congres voor studenten geneeskunde, commissie wetenschap). In 2001 behaalde ze het artsendiploma en werkte ze vervolgens als AGIKO aan dit proefschrift. In 2005 startte ze met de opleiding tot chirurg aan het Academisch Ziekenhuis Maastricht (opleider Prof Greve) en vanaf juli 2007 aan het Maxima Medisch Centrum Eindhoven (opleider Dr Prakken). 